\title{
Rapid Bioassessment Methods for Accessing the Toxicity of Terrestrial Waste Sites at the Savannah River Site Using the Earth Worm, Eisenia Foetida
}

by

W. L. Specht

Westinghouse Savannah River Company

Savannah River Site

Aiken, South Carolina 29808

S. N. Sydow

Clemson University

SC USA

DOE Contract No. DE-AC09-89SR18035

This paper was prepared in connection with work done under the above contract number with the U.S.

Department of Energy. By acceptance of this paper, the publisher and/or recipient acknowledges the U. S. Government's right to retain a nonexclusive, royalty-free license in and to any copyright covering this paper, along with the right to reproduce and to authorize others to reproduce all or part of the copyrighted paper. 



\section{DISCLATMER}

This report was prepared as an account of work sponsored by an agency of the United States Government. Neither the United States Government nor any agency thereof, nor any of their employees, makes any warranty, express or implied, or assumes any legal liability or -responsibility for the accuracy, completeness, or usefulness of any information, apparatus, product, or prosess disclosed, or represents that its use would not infringe privately owned rights. Reference herein to any specific commercial product, process, or service by trade name, trademark, manufacturer, or otherwise does not necessarily constitute or imply its endorsement, recommendation, or favoring by the United States Government or any agency thereof. The views and opinions of authors expressed herein do not necessarily state or reflect those of the United States Government or any agency thereof.

This report has been reproduced directly from the best available copy.

Available to DOE and DOE contractors from the Office of Scientific and Technical Information, P.O. Box 62, Oak Ridge, TN 37831; prices available from (615) 57.6-8401.

Available to the public from the National Technical-Information Service, U.S. Department of Commerce, 5285 Port Royal Road, Springfield, VA 22161. 



\title{
RAPID BIOASSESSMENT METHODS FOR ASSESSING THE TOXICITY OF TERRESTRIAL WASTE SITES AT THE SAVANNAH RIVER SITE USING THE EARTHWORM, Eisenia foetida (U)
}

\author{
by \\ WINONA L. SPECHT \\ SAVANNAH RIVER TECHNOLOGY CENTER \\ and \\ STEPHEN N. SYDOW \\ CLEMSON UNIVERSITY
}

Approved by:

\author{
DBrnove-sacus \\ D.B. Moore-Shedrow, Section Manager \\ Environmental Sciences Section \\ Savannah River Technology Center
}

Publication Date: $\quad$ August 1995

WESTINGHOUSE SAVANNAH RIVER COMPANY

SAVANNAH RIVER SITE

AIKEN, SC 29808

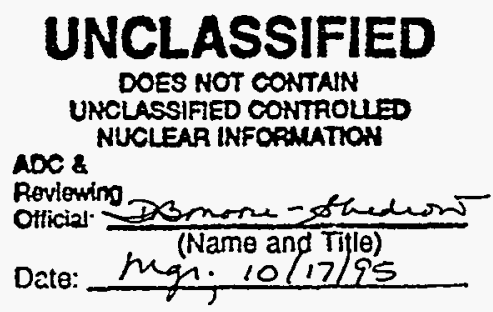

THIS DOCUMENT WAS PREPARED IN CONNECTION WITH WORK UNDER U.S. DEPARTMENT OF ENERGY CONTRACT DE-AC09-88SR18035. By acceptance of this paper, the publisher and/or recipient acknowledges the U.S. Government's right to retain a nonexclusive, royalty-free license in and to any copyright covering this paper, along with the right to reproduce and to authorize others to reproduce all or any part of the copyrighted paper. 
EXECUTIVE SUMMARY

$\begin{array}{lll}1.0 & \text { INTRODUCTION } & 1\end{array}$

2.0 METHODS 2

2.1 Culture Methods 2

2.2 Soils 2

2.3 Toxicity Tests 2

3.0 RESULTS 4

3.1 Evaluations of Uncontaminated SRS Soils 4

3.1.1 Soil Sources/Characteristics 4

3.1.2 Results of Toxicity Tests Conducted on Uncontaminated Soils 5

3.2 Acute Toxicity Tests of SRS Waste Site Soils 5

3.2.1 Soil Sources/Characteristics 5

3.2.2 Results of Acute Toxicity Tests Conducted on SRS Waste Site Soils 6

3.3 Results of Toxicity Tests Conducted Using a Reference Toxicant 8

3.4 Sublethal Responses of Eisenia foetida to SRS Waste Site Soils 8

3.4.1 Burrowing Time 9

3.4.2 Weight Loss 9

3.4.3 Distribution in the Soil 11

3.4.4 Bioaccumulation of Metals 11

$\begin{array}{lll}4.0 & \text { CONCLUSIONS } & 12\end{array}$

$\begin{array}{lll}5.0 & \text { REFERENCES } & 12\end{array}$

APPENDIX 1 Bench Sheets for Toxicity Testing of Uncontaminated Soils

APPENDIX 2 Bench Sheets for Toxicity Testing of Contaminated Soils

APPENDIX 3 Bench Sheets for Sublethal Responses Toxicity Tests

APPENDIX 4 Results of Mann-Whitney U Tests

APPENDIX 5 Metal Concentrations in Test Soils and Earthworms 


\section{LIST OF TABLES}

\section{PAGE}

TABLE 2-1. Soils Selected for Acute Toxicity Testing with Eisenia foetida 3

TABLE 3-1 Characteristics of Orangeburg, Burma Road Clay, and 4 Dorovan Soils

TABLE 3-2 Percent Survival of Eisenia foetida in Amended and Unamended SRS Reference (Uncontaminated) Soils

TABLE 3-3 Soil Characterization Data for Test Soils 6

TABLE 3-4 Metal Concentrations $(\mathrm{mg} / \mathrm{kg})$ of Reference Soils 7 and Waste Site Soils

TABLE 3-5 Percent Survival of Eisenia foetida in SRS Waste Site Soils 7

TABLE 3-6 Percent Survival of Eisenia foetida in Toxicity Tests of 8 a Reference Toxicant (2-Chloracetamide)

TABLE 3-7 Sublethal Responses of Eisenia foetida to Several Waste 10 Site Soils

6

7

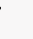

8

TABLE 3-8 Results of Mann-Whitney U Tests for Burrowing Time 9

TABLE 3-9 Average Metal Concentrations $(\mathrm{mg} / \mathrm{kg})$ in Eisenia foetida Exposed to Reference and Waste Site Soils 


\section{EXECUTIVE SUMMARY}

Studies were conducted to assess the feasibility of using the earthworm Eisenia foetida to evaluate the toxicity of contaminated soils at the Savannah River Site. Survival was assessed in several uncontaminated soils, including sandy loams and clayey loams, as well as in soils contaminated with coal fines, ash, diesel fuel, and heavy metals. In addition, behavioral responses, changes in biomass, and bioaccumulation of heavy metals were assessed as sublethal indicators of toxicity.

The results indicate excellent survival of Eisenia foetida in uncontaminated sandy and clayey soils. No amendment of these uncontaminated soils or addition of food was necessary to sustain the worms for the 14-day test period. In contaminated soils, no significant mortality was observed, except in soils have very low pH $(<3)$. However, sublethal responses were observed in earthworms exposed to several of the contaminated soils. These responses included worms clumping on the surface of the soil, worms clumping between the sides of the test container and the soil, increased burrowing times, reductions in biomass, and elevated concentrations of heavy metals in worm tissue.

In conclusion, earthworm mortality is not a sensitive indicator of SRS soil contamination, as evidenced by good survival of the earthworms in grossly contaminated soils. However, several sublethal responses were identified that can be used in assessing soil toxicity to earthworms. These responses include increases in burrowing time, increased weight loss, and bioaccumulation of heavy metals.

\section{$1.0 \quad$ INTRODUCTION}

Soil toxicity tests, using the earthworm Eisenia foetida, are a widely recognized tool for evaluating the toxicity of contaminated soils. Earthworms are ideal test organisms, due to their continual contact with the soil, their ingestion of soil particles, and ease of culture in the laboratory. Toxicity tests with earthworms are relatively simple and inexpensive to perform and the test results can be used not only to determine soil toxicity, but can also be used to determine uptake of soil contaminants by the worms and the potential for movement of contaminants up the food chain.

Although earthworm toxicity tests may be a valuable screening tool for the rapid assessment of waste sites at SRS and other DOE facilities, existing data indicate that Eisenia does best in loamy soils that have relatively high amounts of humus or other organic material, but generally will not survive for extended periods of time in the sandy and heavy clay soils that are common throughout much of the SRS (Edwards, 1992). Therefore, if toxicity assessments are performed using Eisenia, it may not be possible to distinguish between poor survival rates resulting from the effects of unsuitable soil texture and those resulting from the presence of contaminants. The primary objective of this task was to assess the feasibility of using earthworms for toxicity screening of waste site soils at SRS, by evaluating worm survival and sublethal responses in various uncontaminated and contaminated soils. 
This investigation involved three sets of experiments. The first set of experiments assessed the survival of Eisenia in several uncontaminated soils from SRS in order to determine if amendment of the soils, via changes in particle size distribution and/or the addition of organic matter was necessary to prevent mortality during the 14-day test period. These tests were necessary in order to be able to separate the effects of unsuitable soil conditions from possible toxic effects of contaminants in waste site soils. The second set of experiments assessed the toxicity of several SRS waste site soils to Eisenia, using mortality as the test endpoint. The final set of experiments focused on sublethal indicators of toxicity with Eisenia, using some of the same waste site soils that were used previously, as well as one additional waste site soil.

\subsection{METHODS}

\subsection{Culture Methods}

The Eisenia foetida earthworms used in these experiments were obtained from Beaver River Associates, West Kingston, Rhode Island in May 1994. Upon receipt, the worms were placed in damp peat moss in three-gallon plastic containers (Rubbermaid tote boxes) and fed wetted alfalfa pellets twice weekly, using the culture methods described in La Tier and Landis, 1993. After a month, the worms were observed to be growing very slowly and there was no evidence of reproduction in the cultures. At this time the worms were transferred to composted horse manure and additional composted manure was added to the surface of the cultures weekly to provide additional food. Approximately every three months the worms were transferred to fresh composted manure, and the old bedding material was discarded. This method of culture yielded healthy cultures of worms with good rates of reproduction. All worms used in the toxicity tests were clitellid adults, with an average weight of greater than $300 \mathrm{mg}$.

\subsection{Soils}

Soils were collected from three uncontaminated locations and five waste site locations (Table 2-1). Approximately $20 \mathrm{~kg}$ of soil was collected at each location. The samples were placed in plastic bags and returned to the laboratory for processing and analyses. In the laboratory, a sample of each soil was dried at $105^{\circ} \mathrm{C}$ for at least 24 hours and water holding capacity was determined (La Tier and Landis, 1993). Organic content was determined by weighing approximately $10 \mathrm{~g}$ of the dried soil to the nearest 0.0001 $\mathrm{g}$, ashing the sample in a crucible at a temperature of $550^{\circ} \mathrm{C}$ for three hours, cooling the sample in a dessicator and reweighing. Organic matter was reported as the difference between dry and ashed weight. Metal analyses were performed on composted manure, synthetic reference soil, and the soils collected from waste sites known to contain metal contaminants, using inductively coupled plasma (ICP).

\subsection{Toxicity Tests}

Toxicity tests were conducted using the methods described in La Tier and Landis, (1993) and summarized as follows. Approximately $220 \mathrm{~g}$ of soil was wetted sufficiently to attain $75 \%$ water holding capacity. The soil was divided into three equal quantities and each aliquot was placed in a glass pint canning jar. Ten adult clitellid earthworms, with average weights of at least $300 \mathrm{mg}$ were placed on the surface of the soil in each 
sample jar and the lids were loosely screwed onto the jar. The jars were placed in an incubator at $22^{\circ} \mathrm{C} \pm 2{ }^{\circ} \mathrm{C}$. At the end of 7 days and 14 days, survival rates were determined by gently shaking the soil from the jars onto a tray and counting the number of worms in the soil. After the 7-day observations, the soil was returned to the jars and the worms were placed back on the surface of the soil.

2-Chloracetamide was used as a reference toxicant in the toxicity tests (La Tier and Landis, 1993). Five concentrations of chloracetamide were added to a synthetic reference soil that consisted of $70 \%$ fine silica sand (70 mesh), $20 \%$ kaolin clay, and $10 \%$ peat moss. The synthetic soil was then hydrated to $75 \%$ moisture content. The LC50 values of the reference toxicant were determined. A negative control was also established using the synthetic soil without chloracetamide, in order to determine survival rates in the absence of the toxicant.

For the waste site soils, mortality was the primary endpoint in the initial round of testing that was performed. However, in subsequent testing, several sublethal indicators, including burrowing time, weight loss, other behavioral observations, and/or metal bioaccumulation were also assessed.

TABLE 2-1. Soils Selected for Acute Toxicity Testing with Eisenia foetida

Uncontaminated Soils

Orangeburg

Burma Road Clay Pit ${ }^{1}$

Dorovan muck ${ }^{2}$
Soil Type

Loamy sand; low organic content

sandy clay loam; low organic content

High water content; high organic content
Waste Site Soils

D-Area Coal Pile Runoff Basin

P-Area Coal Pile Runoff Basin

A-Area Burning Rubble Pit

Silverton Road Site

Steed's Pond
Contaminants

Metals, low pH

Metals, low pH

Ash, metals

Diesel fuel

Uranium, other metals

\footnotetext{
'Not a soil type, but a location. Includes subsoil layer of Orangeburg Association, but contains a much higher percentage of clay.

${ }^{2}$ This soil was characterized, but not used for toxicity testing, due to changes in soil structure that occurred during drying
} 


\subsection{RESULTS}

\subsection{Evaluations of Uncontaminated SRS Soils}

\subsubsection{Soil Sources/Characteristics}

Three uncontaminated soil types were collected for toxicity evaluations: Orangeburg, Dorovan, and soil from the edges of the Burma Road clay pit. These three locations are representative of sandy loams, organic wetland soils, and clayey loams, respectively, and together provide a reasonable representation of the major types of soil that are present at the SRS. The characteristics of each of these soils is presented in Table 3-1.

Table 3-1. Characteristics of Orangeburg, Burma Road Clay, and Dorovan Soils

\section{Parameter}

Percent clay

Percent organic matter

$\mathrm{pH}$

Moist bulk density ( $g / c c)$

Permeability (in/hr)

Water capacity (in/in)

\section{Orangeburg}

4 to 10

0.5 to 2

4.5 to 5.5

1.35 to 1.55

2.0 to 6.0

0.06 to 0.09

\section{Burma Road Clay}

20 to 45

0.5 to 2

4.5 to 5.5

1.60 to 1.75

0.6 to 2.0

0.11 to 0.14
Dorovan

5 to 20

$>60$

3.6 to 4.4

0.25 to 0.40

0.6 to 2.0

Source: U.S. Department of Agriculture, Soil Conservation Service. 1990. Soil Survey of Savannah River Plant Area, Parts of Aiken, Barnwell, and Allendale Counties, South Carolina.

The Dorovan soil was an extremely wet organic muck that contained approximately $60 \%$ organic material. When performing soil toxicity tests, soils are typically dried and then rehydrated to $70 \%$ water holding capacity. When the Dorovan soil was dried, it formed dried chunks of soil that would not rehydrate to a soil which resembled its original condition. Therefore, although water holding capacity and percent organic content were determined for this soil, toxicity tests were not performed with it. The remainder of Section 3.1 focuses on the Orangeburg and Burma Road clay pit soils.

In the initial investigations, it was believed that some amendment of the soils would probably be necessary to provide suitable substrate for the earthworms, so in addition to performing toxicity tests on these two soils, the Orangeburg soil was modified by sieving it through a 60 mesh sieve, in order to remove coarse sands. In addition, unsieved Orangeburg and Burma Road clay pit soils were amended by adding $5 \%$ and $10 \%$ (by weight) organic matter (peat moss) to the soil. Toxicity tests were run on these amended soils concurrently with the unamended soils. 


\subsubsection{Results of Toxicity Tests Conducted on Uncontaminated Soils}

The results of the toxicity tests that were performed on uncontaminated soils are summarized in Table 3-2 and presented in entirety in Appendix 1.

TABLE 3-2 Percent Survival of Eisenia foetida in Amended and Unamended SRS Reference (Uncontaminated) Soils.

$\begin{array}{lcccc}\text { SOIL TYPE } & \text { REP. 1 } & \text { REP. 2 } & \text { REP. 3 } & \text { MEAN } \\ & & & & \\ \text { Orangeburg } & 100 \% & 100 \% & 80 \% & 93 \% \\ \text { Orangeburg + 5\% organic } & 100 \% & 100 \% & 100 \% & 100 \% \\ \text { Orangeburg + 10\% organic } & 100 \% & 100 \% & 90 \% & 97 \% \\ \begin{array}{l}\text { Orangeburg, 60 mesh } \\ \text { Orangeburg, 60 mesh +5\% }\end{array} & 100 \% & 100 \% & 100 \% & 100 \% \\ \begin{array}{l}\text { organic } \\ \text { Orangeburg, 60 mesh + }\end{array} & 100 \% & 100 \% & 100 \% & 100 \% \\ \begin{array}{l}10 \% \text { organic } \\ \text { Burma Road clay pit }\end{array} & 100 \% & 100 \% & 100 \% & 100 \% \\ \begin{array}{l}\text { Burma Road + 5\% organic } \\ \text { Burma Road + 10\% organic }\end{array} & 100 \% & 100 \% & 90 \% & 97 \% \\ \end{array}$

The results of the toxicity tests show acceptable levels of survival $(\geq 90 \%)$ for all of the unamended and amended soils that were tested. These results indicate that the sandy and clayey soils that dominate the SRS will support earthworms for the duration of a 14-day test and the results suggest that amendment of waste site soils will probably be unnecessary, unless the waste site soils are extremely coarse-grained.

\subsection{Acute Toxicity of SRS Waste Site Soils}

\subsubsection{Soil Sources/Characteristics}

Five waste site soils from the SRS were evaluated for acute toxicity. These soils and classes of toxicants associated with them are listed in Table 2-1. Soil Characterization data are presented in Table 3-3. Metal analyses for the D-Coal Pile Runoff Basin, PCoal Pile Runoff Basin, and Steed's Pond, as well as for the composted bedding material and a synthetic reference soil are presented in Table 3-4.

The results of the metals analyses indicate that the compost had higher concentrations of calcium, potassium, magnesium, manganese, sodium, and zinc that the waste site soils. The synthetic reference soil had higher concentrations of calcium than the waste site soils. Of the remaining metals, most were higher in the waste site soils than in the compost or synthetic reference soil. The two coal pile runoff basin soils were fairly similar, with greatly elevated concentrations of aluminum and iron, and somewhat 
elevated concentrations of arsenic, barium, beryllium, cadmium, cobalt, chromium, nickel, lead and vanadium.

Steed's Pond had very high concentrations of aluminum, chromium, iron, nickel, uranium, and vanadium, and somewhat elevated concentrations of arsenic, barium, beryllium, cadmium, cobalt, copper, and lead. Concentrations in the soils vs. earthworms is discussed in Section 3.4.4.

\section{Table 3-3 Soil Characterization Data for Test Soils}

Soil $\quad \mathrm{pH} \%$ Organic Content $\begin{gathered}\text { Water Holding } \\ \text { Capacity }\end{gathered}$

June-July 1994

$\begin{array}{lccc}\text { Orangeburg } & 5.20 & 1.90 & 27.86 \mathrm{ml} / 100 \mathrm{~g} \\ \text { Burma Road Clay } & 5.04 & 1.24 & 40.68 \mathrm{ml} / 100 \mathrm{~g} \\ \text { Dorovan } & 4.05 & 72.53 & 166.6 \mathrm{ml} / 100 \mathrm{~g} \\ \begin{array}{l}\text { Silverton Road Waste } \\ \text { Site }\end{array} & 5.71 & 16.66 & 106.49 \mathrm{ml} / 100 \mathrm{~g} \\ \begin{array}{l}\text { A-Area Burning Rubble } \\ \text { Pit }\end{array} & 5.46 & 4.03 & 26.32 \mathrm{ml} / 100 \mathrm{~g} \\ \begin{array}{l}\text { D-Coal Pile Runoff } \\ \text { Basin }\end{array} & 2.61 & 18.52 & 46.02 \mathrm{ml} / 100 \mathrm{~g} \\ \begin{array}{l}\text { P-Coal Pile Runoff } \\ \text { Basin }\end{array} & 3.39 & 18.83 & 52.53 \mathrm{ml} / 100 \mathrm{~g} \\ \end{array}$

April 1995

D-Coal Pile Runoff

Basin

DCPRB + Compost $\quad 2.62$

P-Coal Pile Runoff $\quad 3.38$

Basin

Steed's Pond $\quad 3.65$

Compost $\quad 5.64$

Artificial Soil $\quad 6.19$

\subsubsection{Results of Acute Toxicity Tests Conducted on SRS Waste Site Soils}

The results of acute toxicity tests conducted on Eisenia foetida in five SRS waste site soils are summarized in Table 3-5 and presented in entirety in Appendix 2. 
Table 3-4 Metal Concentrations $(\mathrm{mg} / \mathrm{kg}$ ) of Reference Soils and Waste Site Soils

$\begin{array}{lccccc}\begin{array}{c}\text { Metal } \\ \text { (mg/kg) }\end{array} & \text { Compost } & \text { Artificial Soil } & \text { DCPRB } & \text { PCPRB } & \text { Steed's Pond } \\ \text { Aluminum } & 877 & 1490 & 4800 & 6020 & 29700 \\ \text { Arsenic } & 0.54 & 2.66 & 27.9 & 12.9 & 17.5 \\ \text { Barium } & 21 & 19.8 & 49.8 & 48.9 & 99.6 \\ \text { Beryllium } & 0.04 & 0.14 & 0.39 & 1.26 & 0.75 \\ \text { Calcium } & 3470 & 1470 & 224 & 380 & 142 \\ \text { Cadmium } & 0.37 & 0.11 & 1.22 & 0.45 & 1.22 \\ \text { Cobalt } & 0.6 & 0.2 & 1.46 & 2.99 & 3.7 \\ \text { Chromium } & 2.09 & 5 & 8.69 & 14.1 & 98 \\ \text { Copper } & 17 & 2.41 & 11.1 & 16.6 & 51.5 \\ \text { Iron } & 1150 & 2070 & 34900 & 12700 & 33700 \\ \text { Potassium } & 1820 & 27.8 & 494 & 140 & 200 \\ \text { Magnesium } & 1560 & 70.7 & 244 & 100 & 241 \\ \text { Manganese } & 174 & 5.77 & 25.6 & 8.59 & 141 \\ \text { Sodium } & 353 & 9.73 & 95.1 & 68.5 & 36 \\ \text { Nickel } & 0.98 & 0.46 & 6.23 & 6.93 & 745 \\ \text { Lead } & 4.85 & 2.65 & 11.1 & 6.5 & 47.5 \\ \text { Antimony } & 0.58 & <D L & 0.15 & 0.25 & 0.37 \\ \text { Selenium } & 1.09 & <D L & 1.42 & 2.01 & 0.75 \\ \text { Uranium } & 0.04 & <D L & 2.17 & 1.37 & 2140 \\ \text { Vanadium } & 2.91 & 10.4 & 23.9 & 32.5 & 73.7 \\ \text { Zinc } & 162 & 2.51 & 12.7 & 7.54 & 55.5\end{array}$

Table 3-5 Percent Survival of Eisenia foetida in SRS Waste Site Soils

SOIL TYPE

June/July 1994

D Coal Pile Runoff Basin $P$ Coal Pile Runoff Basin ${ }^{1}$

A Burning Rubble Pit

Silverton Road Site

March/April 1995

D Coal Pile Runoff Basin

D CPRB $+50 \%$ compost

$P$ Coal Pile Runoff Basin

Steed's Pond
REP. 1 REP. 2 REP. 3 MEAN

$\begin{array}{cccc}100 \% & 100 \% & 100 \% & 100 \% \\ 100 \% & & & 100 \% \\ 90 \% & 90 \% & 90 \% & 90 \% \\ 100 \% & 100 \% & 100 \% & 100 \%\end{array}$

$\begin{array}{cccc}0 \% & 0 \% & 0 \% & 0 \% \\ 100 \% & 100 \% & 100 \% & 100 \% \\ 100 \% & 100 \% & 100 \% & 100 \% \\ 100 \% & 100 \% & 100 \% & 100 \%\end{array}$

${ }^{1}$ Only one replicate was tested. 
The results indicate that with the exception of the D-Area coal pile runoff basin in April 1995, the waste site soils were not acutely toxic to Eisenia foetida. This waste site soil was not toxic when tested in July 1994. The difference in toxicity results in probably due to differences in $\mathrm{pH}$ The toxicity tests were performed on samples collected at different times (July and March) In July, the pH of the soil sample that was tested was 2.84 , while the $\mathrm{pH}$ of the soil sample that was collected in March was substantially lower (2.33; Table 3-3). These toxicity results suggest that mortality of Eisenia foetida is not a sensitive indicator of contamination for SRS waste site soils, since the soils that were tested contained very high concentrations of contaminants.

\subsection{Results of Toxicity Tests Conducted Using a Reference Toxicant}

Two positive control toxicity tests were also performed using the reference toxicant, 2chloracetamide, in order to document the sensitivity of the worms to a chemical for which there well-documented toxicity data (Table 3-6). These results indicate that the LC50 values $(41.75$ and $47.5 \mathrm{mg} / \mathrm{kg}$ ) are reasonably close to the value reported in the literature (38.5 mg/kg; Edwards, 1984). These results suggest that the worms from our culture were healthy and responded normally to the reference toxicant. They also suggest that the responses of the worms in the waste site soils are credible.

Table 3-6 Percent Survival of Eisenia foetida in Toxicity Tests of a Reference Toxicant (2-Chloracetamide)

Test Conducted in September 1994

$\begin{array}{ccccc}\text { Concentration (mg/kg) } & \text { Rep. 1 } & \text { Rep. 2 } & \text { Rep. 3 } & \text { Mean } \\ 0 & 100 \% & 100 \% & 100 \% & 100 \% \\ 28.5 & 100 \% & 100 \% & 100 \% & 100 \% \\ 38.5 & 90 \% & 100 \% & 100 \% & 97 \% \\ 50 & 20 \% & 70 \% & 20 \% & 37 \%\end{array}$

$\mathrm{LC} 50=47.5 \mathrm{mg} / \mathrm{kg}$

Test Conducted in April 1995

$\begin{array}{ccccc}\text { Concentration }(\mathrm{mg} / \mathrm{kg}) & \text { Rep. 1 } & \text { Rep. 2 } & \text { Rep. 3 } & \text { Mean } \\ 0 & 100 \% & 100 \% & 100 \% & 100 \% \\ 30 & 100 \% & 100 \% & 90 \% & 97 \% \\ 38.5 & 80 \% & 60 \% & 80 \% & 73 \% \\ 45 & 20 \% & 20 \% & 20 \% & 20 \% \\ 55 & 0 \% & 0 \% & 0 \% & 0 \%\end{array}$

$\mathrm{LC} 50=41.8 \mathrm{mg} / \mathrm{kg}$

\subsection{Sublethal Responses of Eisenia foetida to SRS Waste Site Soils}

In the third round of testing, soils collected from the D-Area Coal Pile Runoff Basin and $P$ Area Coal Pile Runoff Basin were retested, with the intent of focusing on sublethal indicators of toxicity. In addition, soil from the old pond bed of Steed's Pond was tested. Steed's Pond received effluents from M-Area and contains elevated concentrations of uranium and other metals. Because the D and P Coal Pile Runoff 
Basin soils contained virtually no organic matter for the worms to eat, one additional treatment was tested, which consisted of a 50/50 mixture of D-Area Coal Pile Runoff Basin soil and compost. In addition to mortality, measurement endpoints included burrowing time, distribution in the soil, initial and final weights of the worms, change in weight, and percent weight loss.

\subsubsection{Burrowing Time}

The average time required for all of the worms to burrow into the soil when initially placed on the surface of the soil ranged from 5.5 minutes for the compost to $>1$ hour for the D-Coal Pile Runoff Basin and D-Coal Pile Runoff Basin + Compost treatments (Table 3-7). In the case of the D-Coal Pile Runoff Basin treatment, the worms never burrowed, but were found dead on the surface of the soil at the end of three days. The time required for the worms to burrow into the compost treatment was statistically compared to each of the other treatments, using a Mann-Whitney U Test. The results indicate that burrowing time was not significantly different for the artificial soil $(p=0.6579)$, but was significantly longer for each of the waste site soils (Table 3-8; Appendix 4). Thus, burrowing time appears to be a good sublethal indicator of potential stress.

Table 3-8. Results of Mann-Whitney U Tests for Burrowing Time and Weight Loss Treatment Burrowing Time Weight Loss

Reference soil

D-Coal Pile Runoff Basin

P-Coal Pile Runoff Basin

D-Coal Pile Runoff

Basin + Compost

Steed's Pond
0.6579

0.0369

0.0495

0.0369

0.0495
0.0495

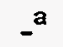

0.0495

0.0495

0.0495

All results are compared to the results for the Compost treatment. $P<0.05$ is statistically significant.

${ }^{a} 100 \%$ mortality; weight loss could not be determined.

\subsubsection{Weight Loss}

The earthworms in each of the treatments, including the compost and the artificial soil lost weight during the course of the 14-day test (Table 3-7), which suggests that the test conditions are somewhat stressful to the worms. The worms were reared in large (40 to 60 liter containers), and it is likely that the stress of the worms being handled while sorting and weighing them, and the stress of being placed into small ( $1 / 2$ liter) containers affected them to some extent. The average percent weight loss of the 
Table 3-7. Sublethal Responses of Eisenia foetida to Several Waste Site Soils

\begin{tabular}{|c|c|c|c|c|c|c|}
\hline PARAMETER & ARTIFICIAL SOIL & COMPOST & STEED'S & P CPRB & D CPRB & CPRB + COMPOST \\
\hline BURROWING TIME (minutes) & 5.6 & 5.5 & 15.7 & 12.3 & a & $>60$ \\
\hline 14-day SURVIVAL & $100 \%$ & $100 \%$ & $100 \%$ & $100 \%$ & $0 \%$ & $100 \%$ \\
\hline INITIAL WEIGHTMORM (g) & 0.308 & 0.306 & 0.302 & 0.298 & 0.296 & 0.302 \\
\hline FINAL WEIGHTMORM $(g)$ & 0.256 & 0.267 & 0.242 & 0.223 & - & 0.242 \\
\hline WEIGHT CHANGE (g) & 0.051 & 0.0393 & 0.0599 & 0.0745 & - & 0.0599 \\
\hline PERCENT WEIGHT LOSS & 16.7 & 12.8 & 19.9 & 25.0 & - & 19.0 \\
\hline DISTRIBUTION & EVEN & EVEN & EVEN & $\begin{array}{l}\text { CLUMPED } \\
\text { NEAR BOTTOM }\end{array}$ & $\begin{array}{l}\text { NEVER } \\
\text { BURROWED }\end{array}$ & EVEN \\
\hline \multicolumn{7}{|l|}{ a Worms never burrowed. } \\
\hline \multicolumn{7}{|c|}{ Steed's $=$ Steed's Pond of Tim's Branch } \\
\hline \multicolumn{7}{|c|}{$P C P R B=P$ Area Coal Pile Runoff Basin } \\
\hline \multicolumn{7}{|c|}{$D C P R B=D$ Area Coal Pile Runoff Basin } \\
\hline D CPRB + Compost $=50 \% D$ & + & & & & & \\
\hline
\end{tabular}


worms during the 14 day test ranged from $12.8 \%$ for the compost to $25 \%$ for P-Coal Pile Runoff Basin. In the case of the D-Coal Pile Runoff Basin treatment, the worms experienced $100 \%$ mortality within a few days, so percent weight loss could not be determined. The percent weight loss was statistically compared to each of the other treatments, using a Mann-Whitney $U$ Test. The results indicate that percent weight loss was significantly greater for each of the treatments, including the artificial soil (Table 39; Appendix 4). Thus, percent weight loss appears to be a good sublethal indicator of potential stress.

\subsubsection{Distribution in the Soil}

Observations during the first round of toxicity tests suggested that worms that were not obviously stressed were found distributed fairly evenly throughout the soil, while those in some of the treatments were found clumped together either in the bottom of the container or against the side of the container between the soil and the glass.

Occasionally, the worms refused to burrow at all and remained clumped together on the surface of the soil. In order to determine the utility of using distribution as a sublethal indicator of stress, the distribution of the earthworms in each treatment was noted. The worms exposed to the D-Coal Pile Runoff Basin soil refused to burrow, while those in the P-Coal Pile Runoff Basin soil were found clumped together in the bottom of the jars. In the remainder of the treatments, the worms were fairly evenly distributed (Table 3-7). This suggests that extreme $\mathrm{pH}$ probably is responsible for the clumping behavior of the worms, but that the worms do not exhibit clumping behavior in some waste site soils. Therefore, although clumping certainly appears to be an indicator of severe stress, even distribution does not necessarily indicate lack of stress.

\subsubsection{Bioaccumulation of Metals}

As discussed in Section 3.2.1, the waste site soils contained elevated concentrations of most of the metals that were tested. However, fewer metals were found at elevated levels in the earthworms. In worms exposed to the coal pile runoff basin soils, aluminum, iron, lead, and nickel were slightly higher than those exposed to compost or artificial soil, but generally concentrations were less than a factor of two higher. However, in earthworms exposed to soil from Steed's Pond, barium, chromium, iron, manganese, lead and vanadium were somewhat elevated, while aluminum, nickel, and uranium were much higher. Aluminum levels were approximately 10 times higher in the Steed's Pond earthworms, nickel concentrations were approximately 25 times higher, and uranium, which was not detected in earthworms from the other treatments (detection limit was approximately $0.5 \mathrm{mg} / \mathrm{kg}$ ) was detected at an average concentration of $116.67 \mathrm{mg} / \mathrm{kg}$ in earthworms from Steed's Pond.

These results indicate that many metals will bioaccumulate in earthworms. Elevated concentrations of these toxicants in earthworms can be used as an indication of exposure, and can also provide information useful in predicting the movement of metals to through the food chain to higher trophic levels. Elevated body burdens of metals is not necessarily an indication of stress, however. Further studies of the physiological responses of earthworms to elevated body burdens may be needed to document stress resulting from metal exposure. 
Table 3-9. Average Metal Concentrations (mg/kg) in Eisenia foetida Exposed to Reference and Waste Site Soils

$\begin{array}{lrrrrr}\text { Metal } & \text { Compost } & \text { Artificial Soil } & \text { DCPRB } & \text { PCPRB } & \text { Steed's Pond } \\ \text { (mg/kg) } & & & & & \\ \text { Aluminum } & 53.83 & 66.1 & 107.27 & 129.67 & 576.67 \\ \text { Arsenic } & 10.46 & 17.19 & 7.58 & 7.67 & 11.4 \\ \text { Barium } & 1.02 & 1.11 & 0.68 & 0.7 & 3.75 \\ \text { Beryllium } & 0 & 0 & 0.01 & 0.01 & 0.01 \\ \text { Calcium } & 3620 & 3630 & 3563.33 & 3473.33 & 2786.67 \\ \text { Cadmium } & 5.94 & 5.87 & 5.1 & 6.12 & 6.5 \\ \text { Cobalt } & 7.99 & 9.93 & 5.82 & 7.59 & 10.03 \\ \text { Chromium } & 0.53 & 0.71 & 0.9 & 0.58 & 2.11 \\ \text { Copper } & 14.53 & 11.57 & 11.47 & 16.63 & 15.8 \\ \text { Iron } & 366.33 & 435.33 & 571.67 & 404.33 & 889.33 \\ \text { Potassium } & 6123.33 & 5840 & 6466.67 & 5306.67 & 5540 \\ \text { Magnesium } & 954 & 669.33 & 701 & 683 & 631.33 \\ \text { Manganese } & 16.6 & 7.36 & 10.05 & 10.38 & 49.17 \\ \text { Sodium } & 6790 & 5143.33 & 6543.33 & 4886.67 & 5363.33 \\ \text { Nickel } & 0.85 & 0.8 & 2.22 & 2.07 & 22.1 \\ \text { Lead } & 1.09 & 1.2 & 1.12 & 1.35 & 6.77 \\ \text { Antimony } & 2.62 & 2.6 & 1.99 & 2.22 & 2.13 \\ \text { Selenium } & 4.27 & 4.6 & 4.11 & 4.74 & 4.67 \\ \text { Uranium } & <0.45 & <0.51 & <0.44 & <0.58 & 116.67 \\ \text { Vanadium } & 0.27 & 0.45 & 0.35 & 0.28 & 1.38 \\ \text { Zinc } & 112.67 & 110.67 & 102.57 & 113.67 & 119.67\end{array}$

\subsection{CONCLUSIONS}

In conclusion, earthworm mortality is not a sensitive indicator of SRS soil contamination, as evidenced by good survival of the earthworms in grossly contaminated soils. However, several sublethal responses were identified that can be used in assessing soil toxicity to earthworms. These responses include increases in burrowing time, increased weight loss, and bioaccumulation of heavy metals in soils that contain elevated levels of metals.

\subsection{REFERENCES}

Edwards, C.A. 1984. Report of the Second Stage in Development of a Standardized Laboratory Method for Assessing the Toxicity of Chemical substances to Earthworms. Report EUR 9360 EN, Commission of the European Communities, 99 pp.

Edwards, C.A. 1992. Testing the Effects of Chemicals on Earthworms: The Advantages and Limitations of Field Tests. in: Greig-Smith, P.W., H. Becker, P.J. Edwards, and F. Heimbach (eds.) Ecotoxicology of Earthworms. Intercept Ltd. Andover, U.K. 
La Tier, A.J. and W,G, Landis. 1993. Soil Toxicology Workshop Methods Manual, Section 1, Earthworm Toxicity Test. Western Washington University, Bellingham, Washington.

U.S. Department of Agriculture, Soil Conservation Service. 1990. Soil Survey of Savannah River Plant Area, Parts of Aiken, Barnwell, and Allendale Counties, South Carolina. 


\section{APPENDIX 1}

Bench Sheets for Toxicity Testing of Uncontaminated Soils 
EARTHWORM TOXICITY TESTING BENCH SHEET

Source Burma Rd Clay Soil Dilution/Concentration $100 Z_{0}$

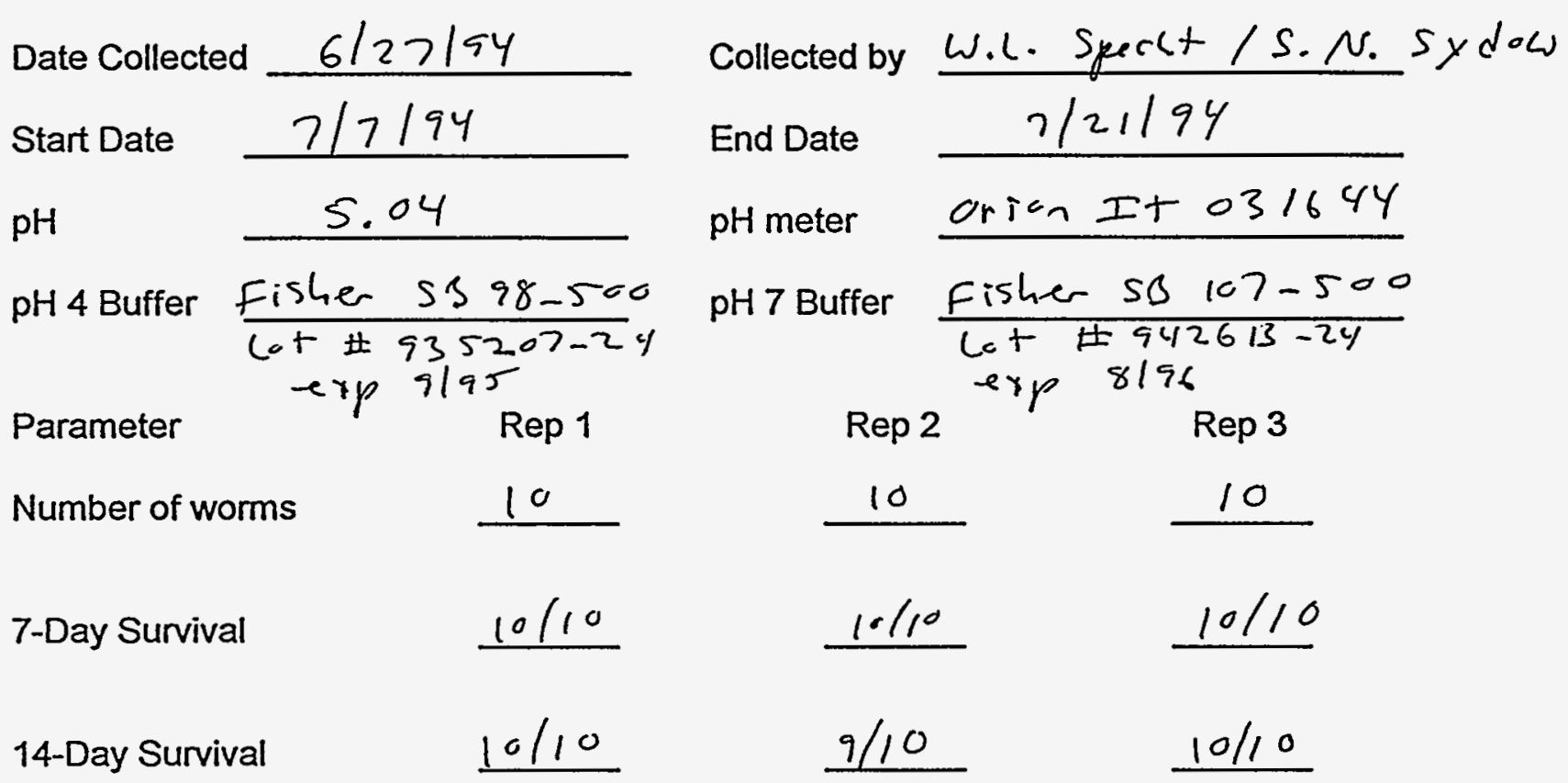

Notes/Observations:

14-doys works didn't re -burrow after 7-doy check.

Rep 3 - ore work very sluggish 
EARTHWORM TOXICITY TESTING BENCH SHEET

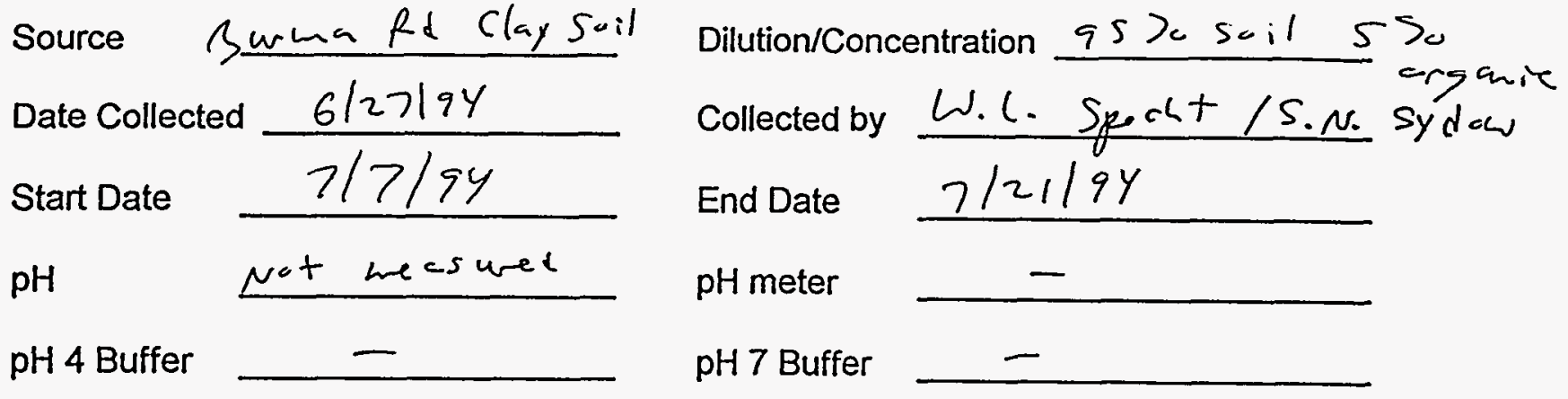

\begin{tabular}{|c|c|c|c|}
\hline Parameter & Rep 1 & Rep 2 & $\operatorname{Rep} 3$ \\
\hline Number of worms & 10 & 10 & 10 \\
\hline 7-Day Survival & $10 / 10$ & $10 / 10$ & $9 / 10$ \\
\hline 14-Day Survival & $10 / 10$ & $10 / 10$ & $9 / 10$ \\
\hline
\end{tabular}

Notes/Observations: 


\section{EARTHWORM TOXICITY TESTING BENCH SHEET}

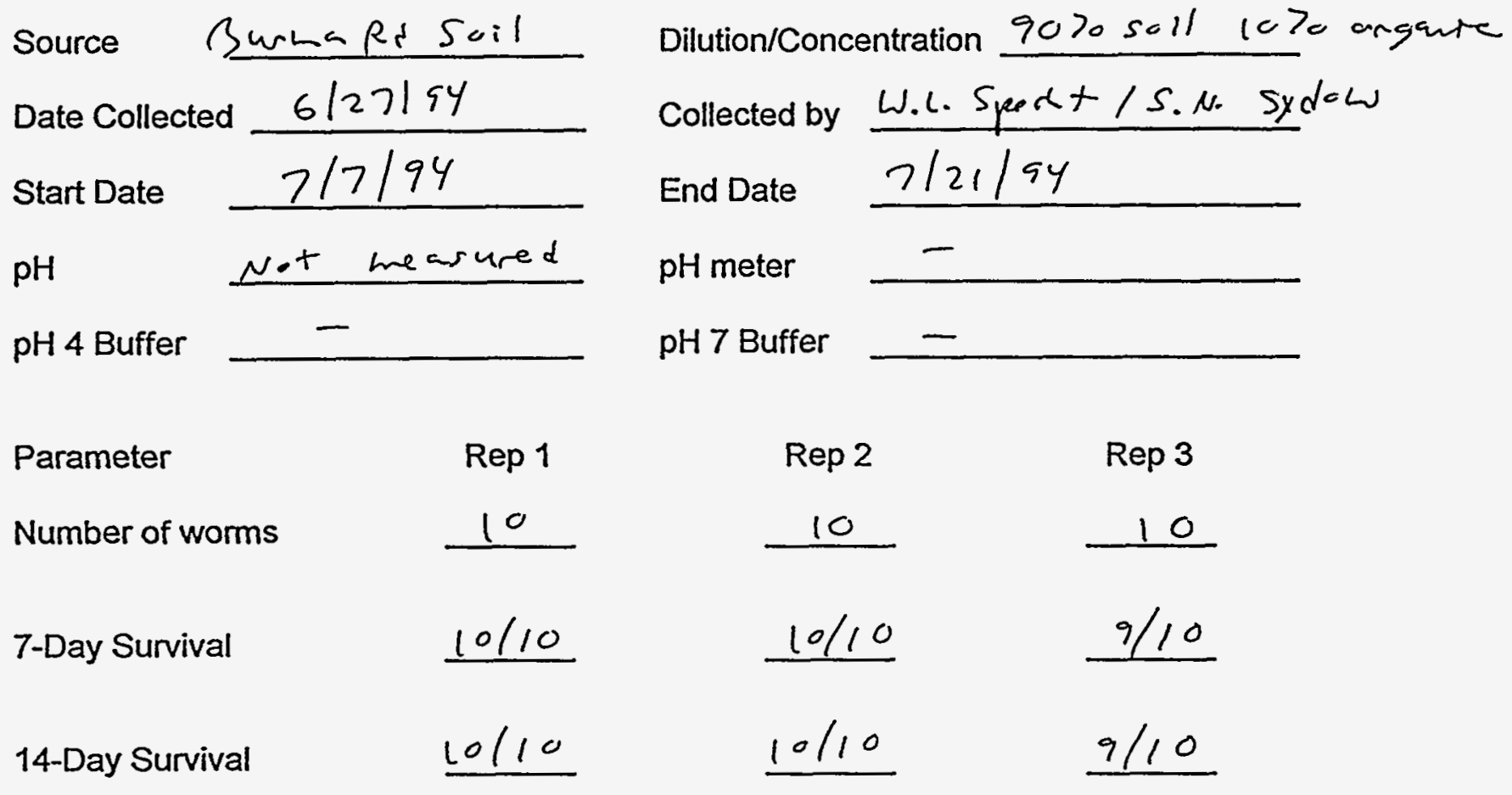

Notes/Observations: 


\section{EARTHWORM TOXICITY TESTING BENCH SHEET}

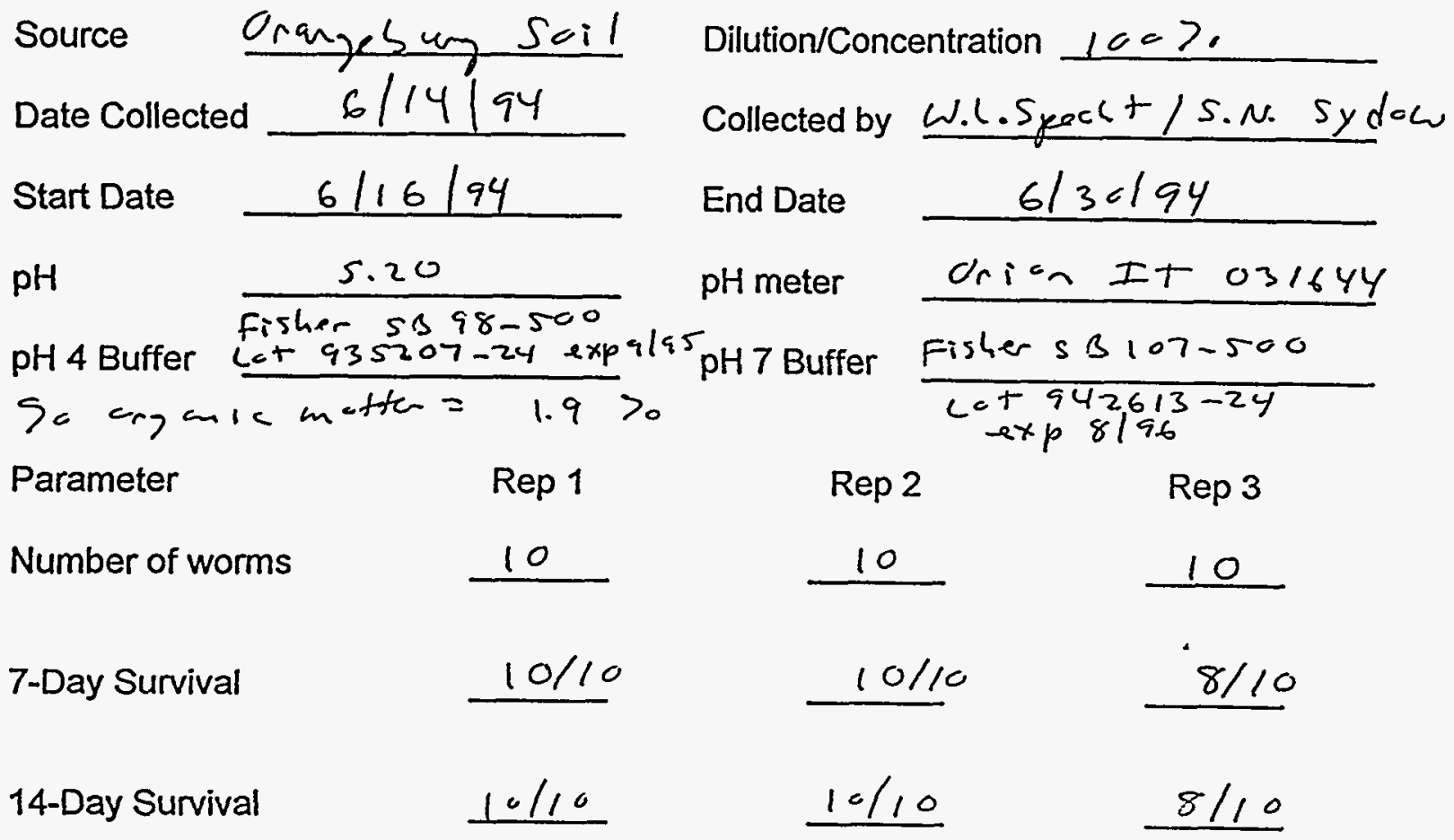

Notes/Observations: 


\section{EARTHWORM TOXICITY TESTING BENCH SHEET}

Source Orangebug Soil

Date Collected $6 / 14 / 94$

Start Date $6 / 16 / 94$

$\mathrm{pH}$ 4.13

pH 4 Buffer

$\frac{\text { Eisher SB98-500 }}{\text { cot } 935207-24}$ exp 9125

Parameter

$\operatorname{Rep} 1$

Dilution/Concentration $\frac{9070 \text { oranges ang }}{1070 \text { onganic }(p e d ~}$

Collected by W.L. Sppect /S.N. Syptew mass)

End Date

$6 / 30 / 54$

$\mathrm{pH}$ meter

$$
\text { urian It } 031644
$$

pH 7 Buffer

$$
\begin{gathered}
\text { Fisber SB } 107-500 \\
\text { Lot } 942613-24 \\
\text { exp } 8196
\end{gathered}
$$

Rep 2

Rep 3

Number of worms

10

10

10

7-Day Survival

$10 / 10$

$10 / 10$

$10 / 10$

14-Day Survival

$10 / 10$

$10 / 10$

$9 / 10$

Notes/Observations: 


\section{EARTHWORM TOXICITY TESTING BENCH SHEET}

\begin{tabular}{|c|c|c|}
\hline Source & Orangesurg soil & \multirow{2}{*}{ 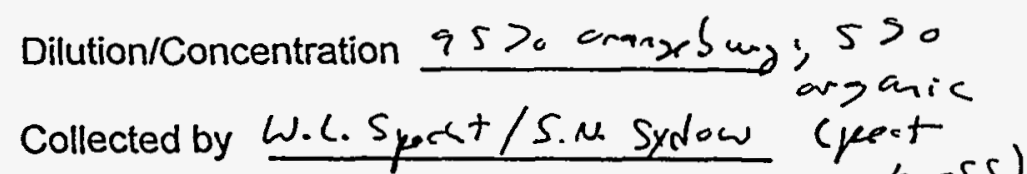 } \\
\hline Date Collected & $6 / 14 / 94$ & \\
\hline Start Date & $6 / 16194$ & 6130194 \\
\hline $\mathrm{pH}$ & 4.06 & drian It 031644 \\
\hline pH 4 Buffer & Fisher SB 98-500 & Fisher SB $107-500$ \\
\hline & $\begin{array}{l}\text { Lat \#935207-24 } \\
\text { exp } 9155\end{array}$ & $\begin{array}{c}\text { cat } 942613-24 \\
\exp 8 / 96\end{array}$ \\
\hline Parameter & Rep 1 & $\operatorname{Rep} 2 \quad \operatorname{Rep} 3$ \\
\hline Number of wor & 10 & 10 \\
\hline 7-Day Survival & $10 / 10$ & $10 / 10$ \\
\hline 14-Day Survive & $10 / 10$ & $10 / 10$ \\
\hline
\end{tabular}

Notes/Observations: 
EARTHWORM TOXICITY TESTING BENCH SHEET

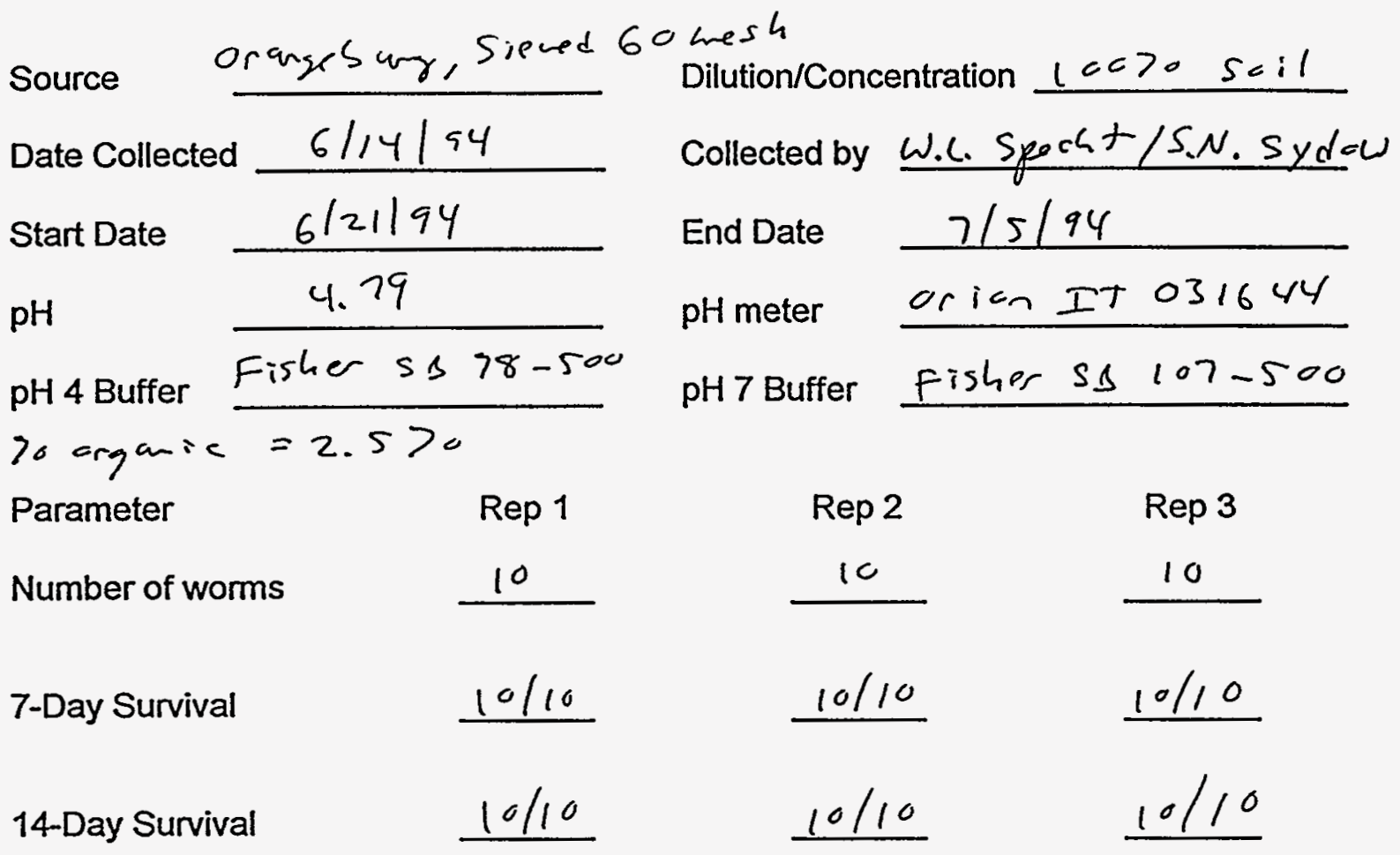

Notes/Observations: 


\section{EARTHWORM TOXICITY TESTING BENCH SHEET}

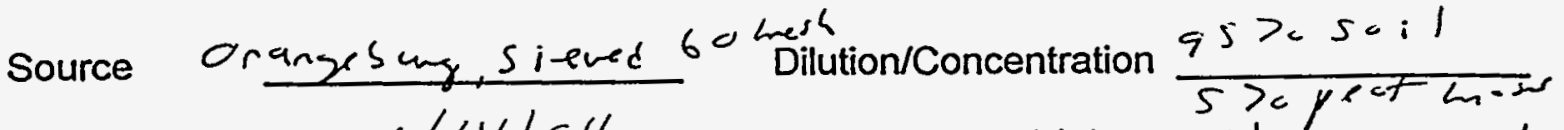

Date Collected $6 / 14 / 94$ $6 / 21 / 94$

Start Date

$\mathrm{pH}$

pH 4 Buffer

Parameter

Number of worms

7-Day Survival

14-Day Survival $\frac{\text { Fisher s3 } 98-500}{\cot 935207-24}$
Collected by W.L. Syect/S.N. Sydow

End Date

715194 4.23 pHmeter Orien It 031644 Let 942613-24

$\operatorname{Rep} 2$

10

$10 / 10$

$10 / 10$
Rep 3

10

$8 / 10$

$8 / 10$
10

$10 / 10$

Notes/Observations: 
EARTHWORM TOXICITY TESTING BENCH SHEET

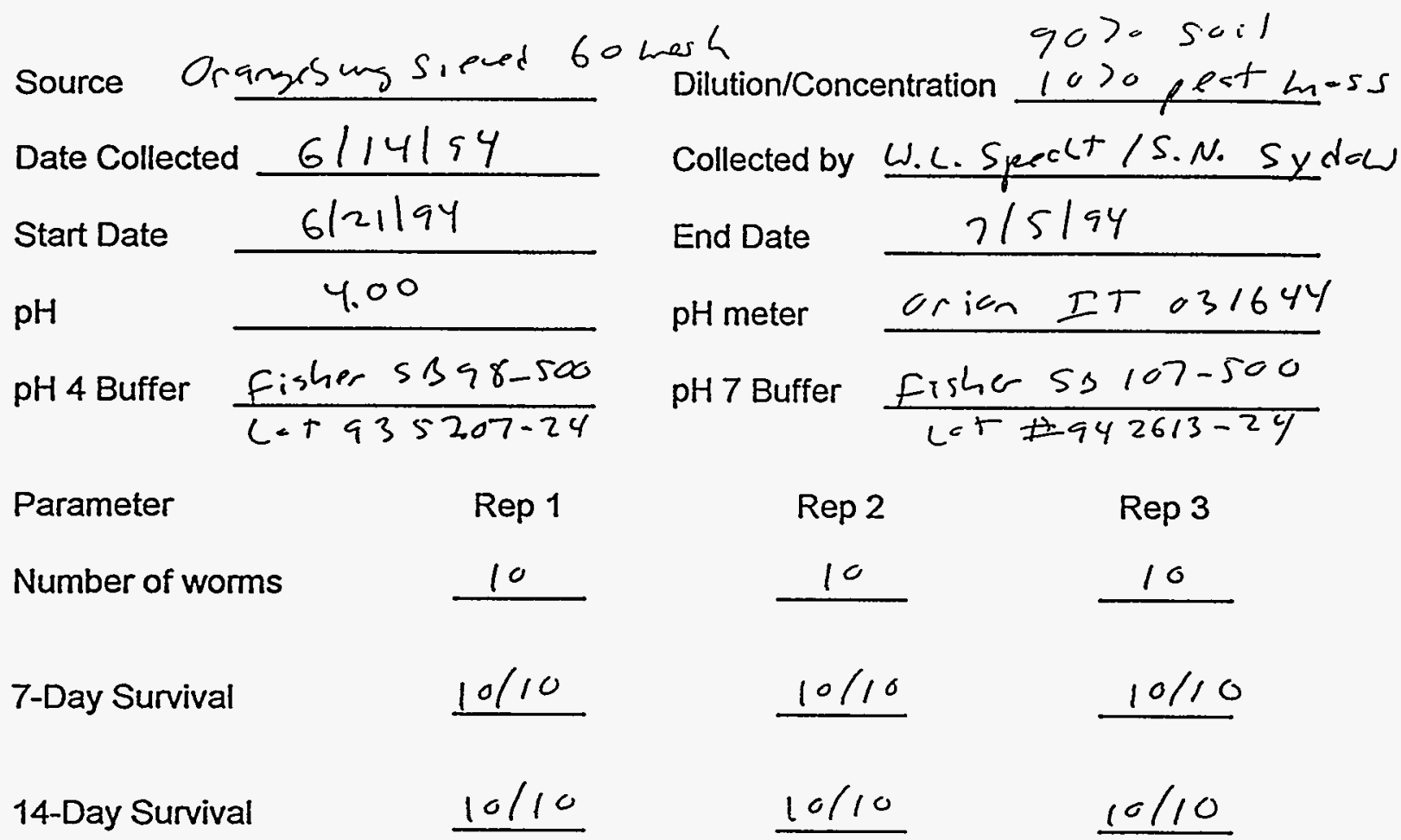

Notes/Observations:

$7-d a x-R e p 1.2$ wares vex slug gish 


\section{APPENDIX 2}

Bench Sheets for Toxicity Testing of Contaminated Soils 
EARTHWORM TOXICITY TESTING BENCH SHEET

Source $\quad$ coal Pile Rmaff sasin Dilution/Concentration 10070

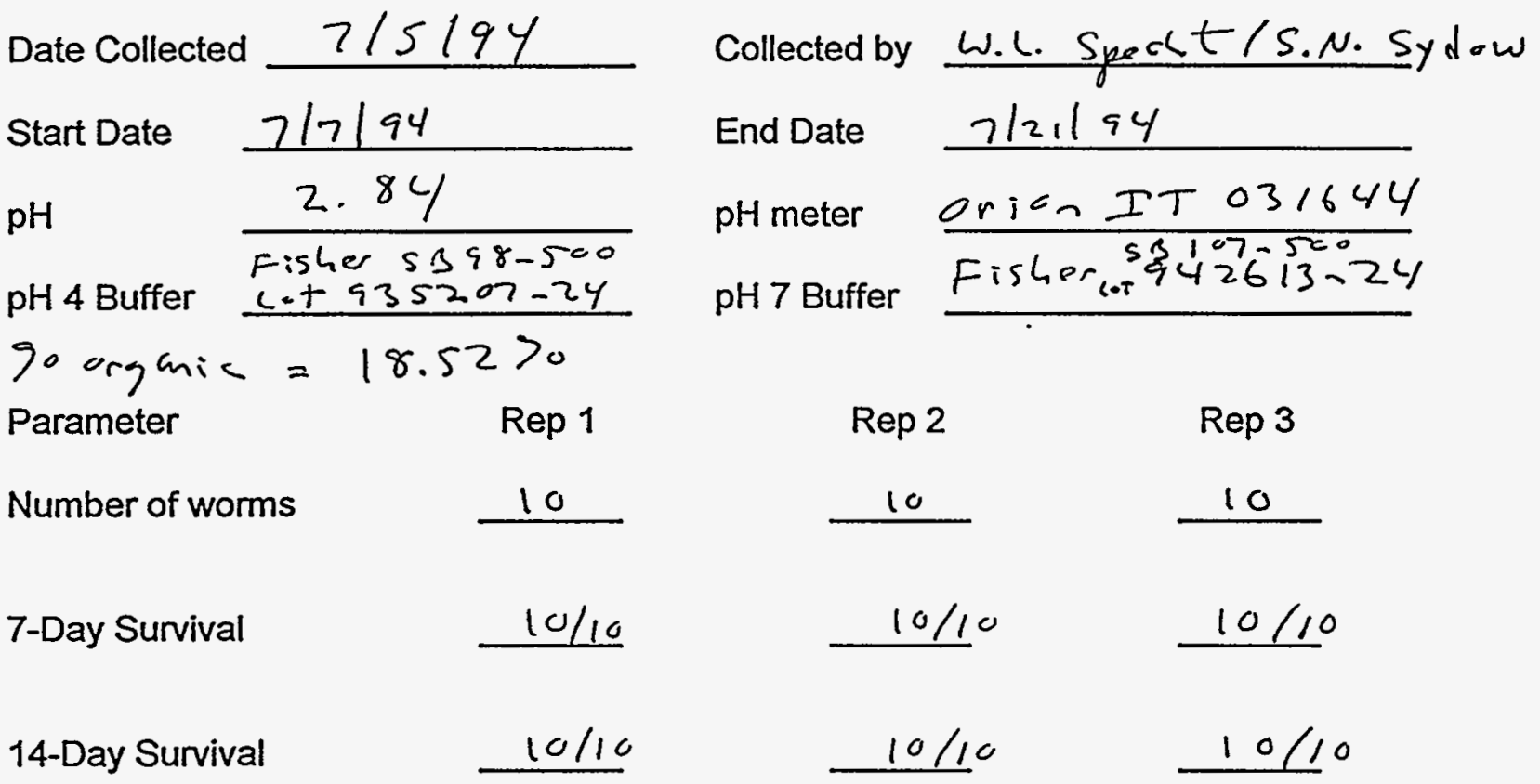

Notes/Observations:

Andy worms woe balled up on surface- had never burrowed. Worms were inactive she first removed, but became active with is 1 minute of removal

$14 d a x$ - worms still balled up on surfacenever burrowed.

contaminant = coal particulates 


\section{EARTHWORM TOXICITY TESTING BENCH SHEET}

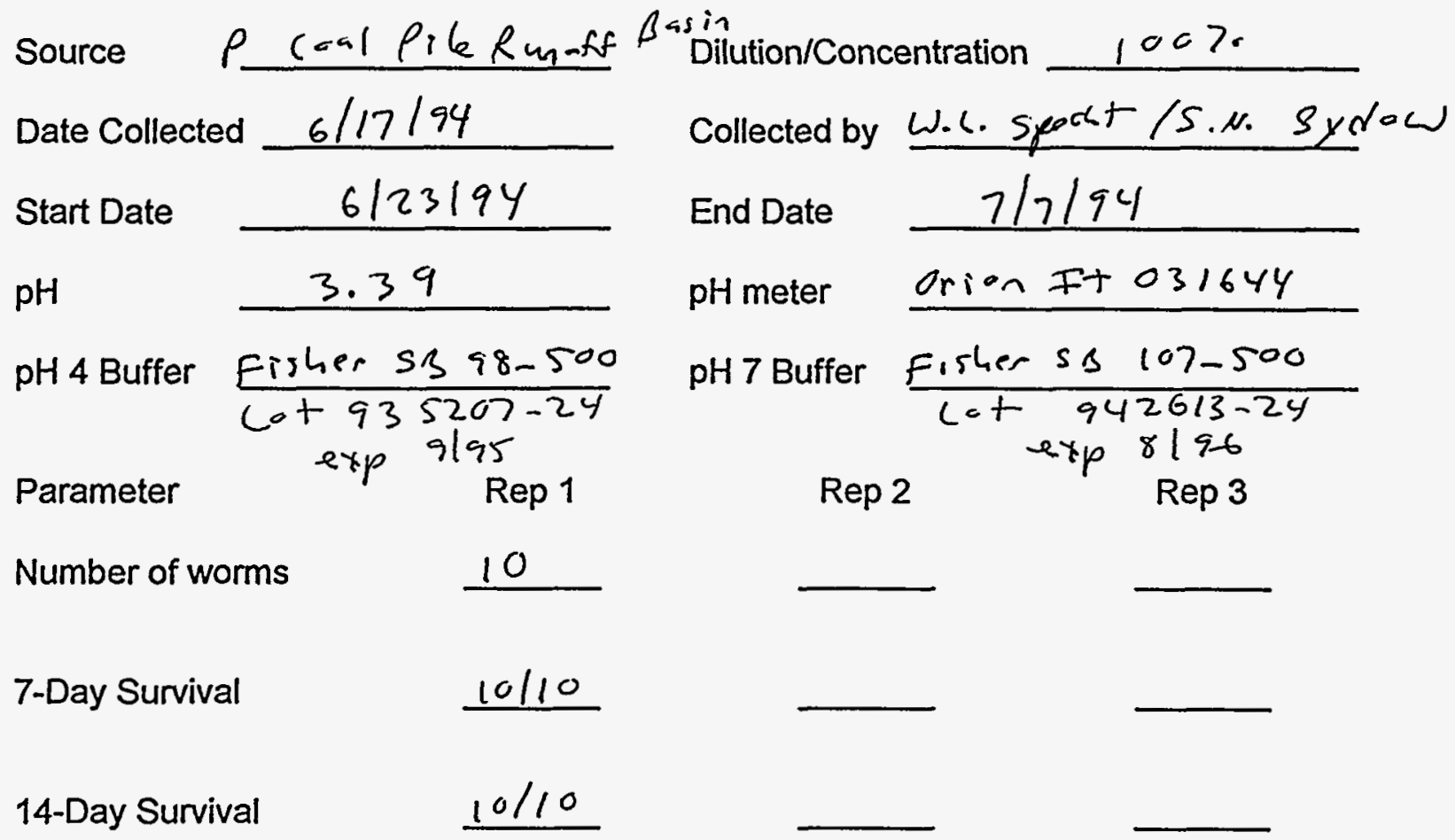

Notes/Observations:

$\frac{\text { Just ran } 1 \text { replicate, since it seemed }}{\text { doubtful that worms can swuive a this }}$
waste soil.

$\frac{14-d a x-\text { guessed wrong. Test will be }}{\text { repeated with } 3 \text { replicates at a later date }}$ 
Source A Area Burning Rcsbk P 1 Dilution/Concentration 10<7. Date Collected 7/5/94 Collected by w.L. Specht/S.n. sydow

Start Date $7 / 6 / 94$

$\mathrm{pH}$

$$
5.46
$$

Fisher so $98-500$

70 orjanic $=4.0370$

Parameter

Rep 1

Number of worms

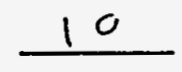

7-Day Survival

14-Day Survival
End Date 7120154

$\mathrm{pH}$ meter

pH 7 Buffer

$$
\begin{aligned}
& \text { Orion It } 031644 \\
& \text { Fisher } 53107-500 \\
& \text { Let } 942613-24 \\
& \hline
\end{aligned}
$$

Rep 3

Rep 2

10

10

$9 / 10$

$10 / 10$

$9 / 10$

$9 / 10$

Notes/Observations:

7-days - works were active a behaving norkally 
EARTHWORM TOXICITY TESTING BENCH SHEET

Source Silverton Burning Rusbledilution/Concentration 10070

Date Collected 2/5194 lit

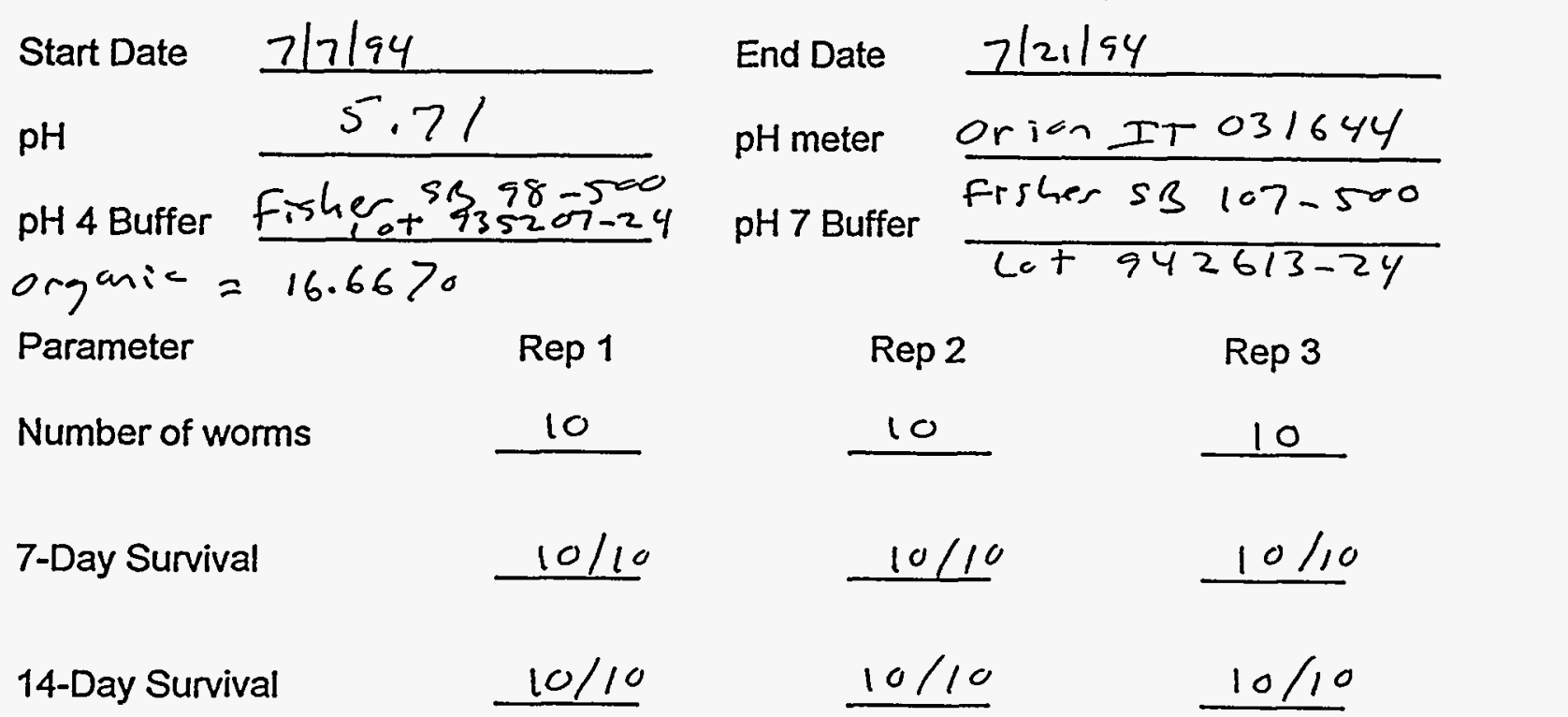

Notes/Observations:

7-dey standing water on top of Reps 102

7-day Rep 1 Ail works found $a$ top half ot $5 \cdot 11$

Reps 203 worms distributed evenly thragheat soil 14 day 1 baby worm in Rep 2

contaminant $=$ ash 


\section{EARTHWORM TOXICITY TESTING BENCH SHEET}

Source 2 -chl-racetabide

Date Collected

Start Date

$9 / 21 / 94$

$\mathrm{pH}$

6.65

pH 4 Buffer

Parameter $\frac{\text { Fisher so } 98-500}{\text { Lot } 935207-24}$ exp $9 / 95$

Rep 1

Number of worms

7-Day Survival

14-Day Survival

$10 / 10$
Dilution/Concentration $0 \mathrm{mg} / \mathbb{K}_{\mathrm{g}}(\mathrm{c}-n+1-1)$

$$
\text { Rin }
$$
Golleeted by W.C. Specht

End Date 1015194

pHmeter orionIt 031644

pH7 Buffer $\frac{\text { Fisher sS 107-500 }}{\text { cotp } 8 / 96}$

Rep 2

$\operatorname{Rep} 3$

10

10

$10 / 10$

$10 / 10$

$10 / 10$

$10 / 10$

Notes/Observations: 


\section{EARTHWORM TOXICITY TESTING BENCH SHEET}

Source $\frac{2 \text {-chloracetamide }}{k e d-4 \text { l.t } 910478}$

Date Collected

Start Date

$9 / 2,19$ of

$\mathrm{pH}$

pH 4 Buffer

Parameter

$$
6.65
$$

$\frac{\text { Fisher sB } 98-500}{\text { Let \#935207-24 }}$ exp 9155

Number of worms

7-Day Survival

14-Day Survival

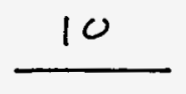

Dilution/Concentration $28.5 \mathrm{mg} / \mathrm{kg}$

Collected by W. L. Spocht

End Date $\quad 10 / 5 / 94$

pHmeter orian It $03 / 644$

pH7 Buffer $\frac{\text { Fisher SB } 107-500}{\text { Lot } 1542613-24}$

- Prp. 8156

Rep 2

Rep 3

10

10

10

10

10

Notes/Observations: 
EARTHWORM TOXICITY TESTING BENCH SHEET

Source 2 -cll-nacotamile

Date Collected

Start Date $\frac{9 / 21 / 54}{\mathrm{pH}} \frac{6.65}{\mathrm{pH} 4 \text { Buffer } \frac{\text { Eisher SB98-500 }}{\text { Let } 935207-24}}$ exp slas

Parameter

Rep 1

Dilution/Concentration $38.5 \mathrm{mg} / \mathrm{k}_{2}$ Collected by W. L. Specelt

End Date

$10 / 5 / 95$

pHmeter Orin IT 03/64Y

$\mathrm{pH} 7$ Buffer

Number of worms

10

$\operatorname{Rep} 2$

Lot $1542613-24$

$\rightarrow$ exp 8196

Number of worms

7-Day Survival

10

10

Rep 3

14-Day Survival

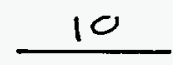

10

10

10

Notes/Observations: 


\section{EARTHWORM TOXICITY TESTING BENCH SHEET}

Source 2-chloracetamide

Date Collected

Start Date $\frac{9 / 21 / 54}{\mathrm{pH}} \frac{6.65}{\mathrm{pH} 4 \text { Buffer } \frac{\text { fisher SB } 58-500}{(0+535207-24}}$

Parameter

exp 9155

Number of worms

7-Day Survival

14-Day Survival
Rep 1

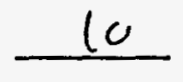

2

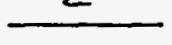

2
Dilution/Concentration $50 \mathrm{hg} / \mathrm{Kg}$ Golleetedby W.C. Sperdt

End Date

$10 / 5 / 94$

pH meter

Orien IT O31644

pH7Buffer Fisher sB 107-500

Rep 2

exp 8196

Rep 3

10

10

7

2

7
2

Notes/Observations: 


\section{APPENDIX 3}

Bench Sheets for Sublethal Responses Toxicity Tests 
EARTHWORM TOXICITY TESTING BENCH SHEET

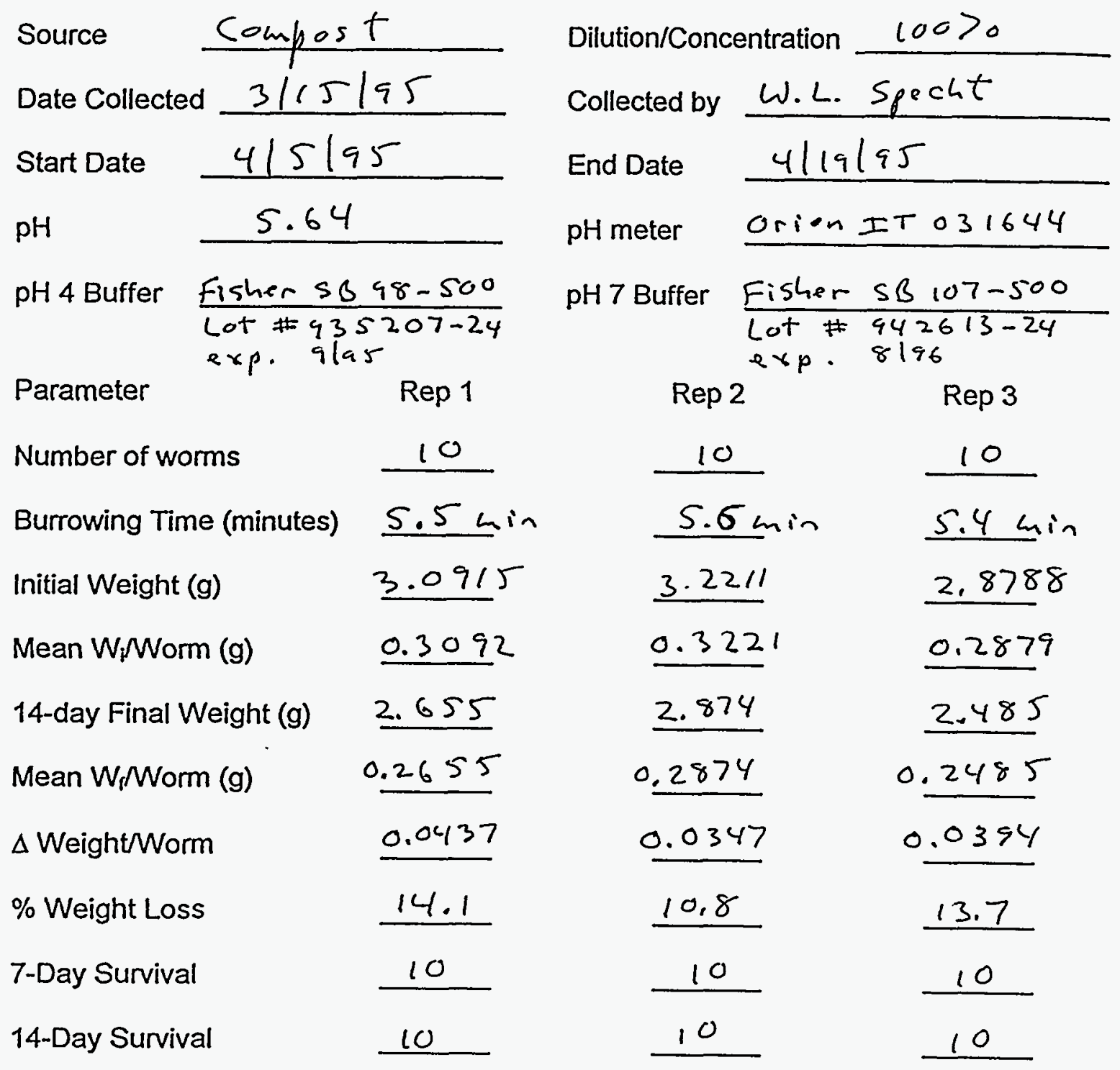

Notes/Observations:

7-day worms were evenly distributed

$14-d-y$ worms wee evenly distributed 
EARTHWORM TOXICITY TESTING BENCH SHEET

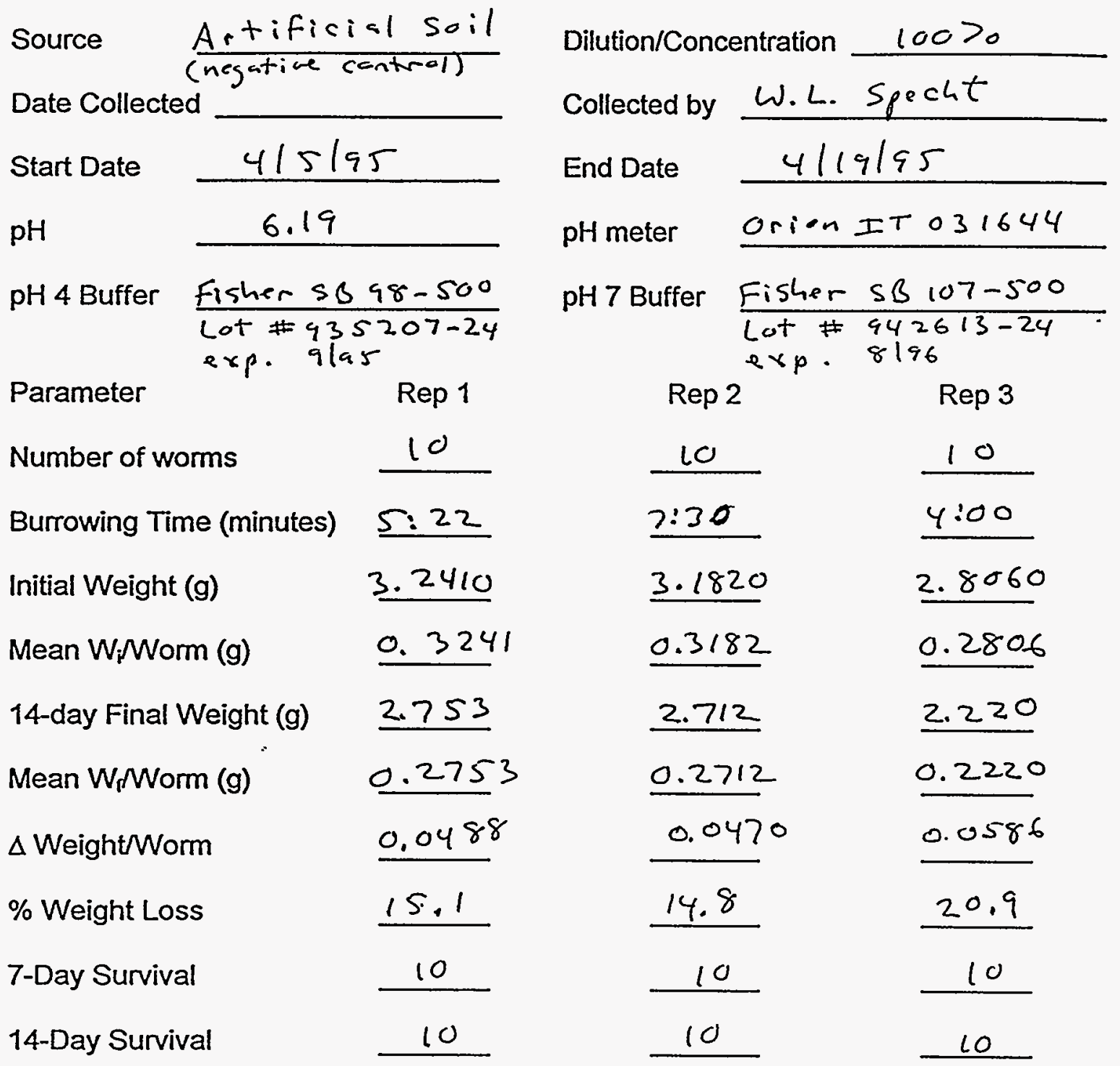

Notes/Observations:

7-day works are evenly distributed

14-day works are evenly distrib coed 
EARTHWORM TOXICITY TESTING BENCH SHEET

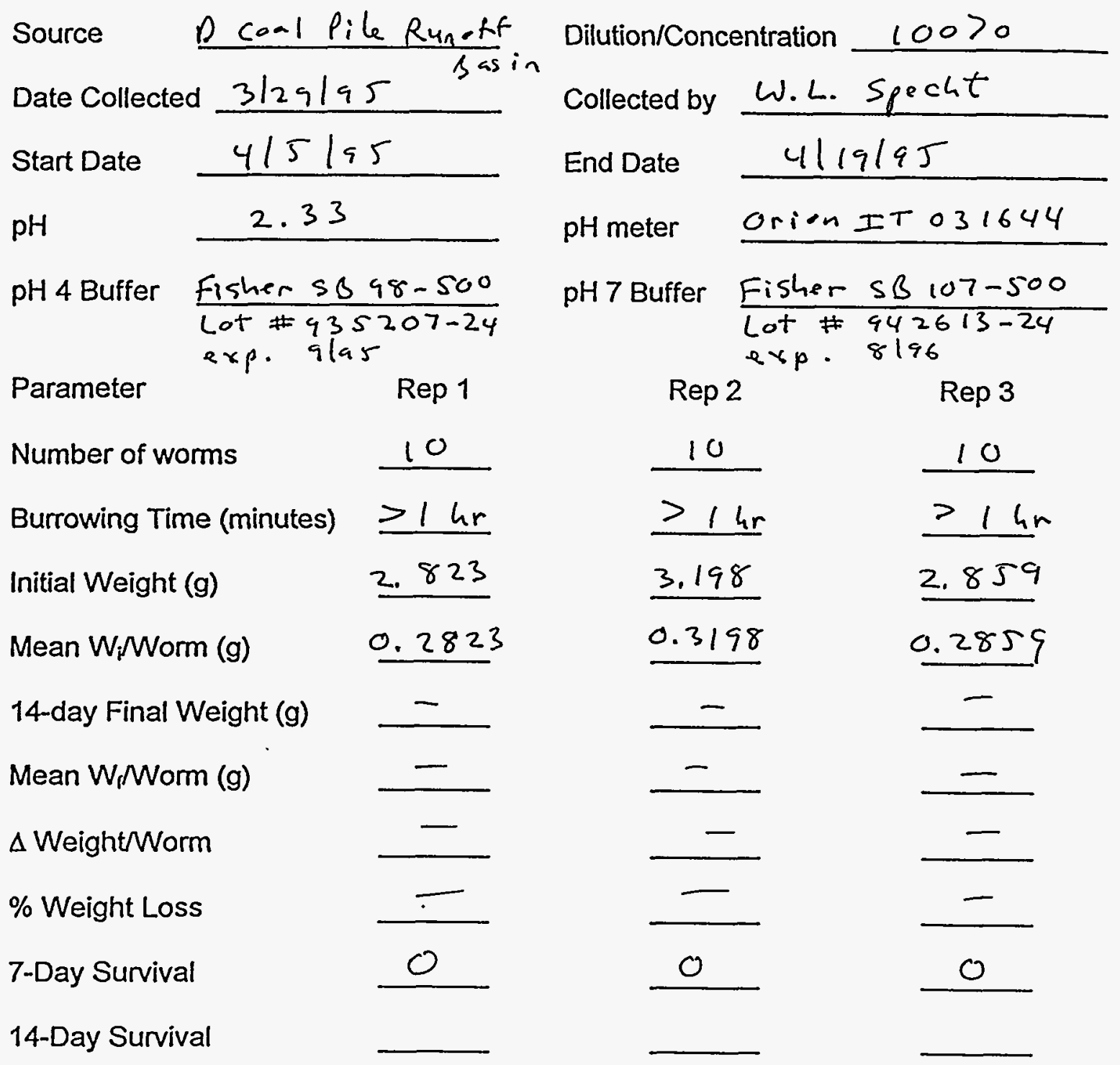

Notes/Observations:

7 -day Reps 192 all worms were on top of the soil dead. They never burrowed. Rep 3 all works were in the bottom, against i the glass 5 , is a clump. All were dead. 
EARTHWORM TOXICITY TESTING BENCH SHEET

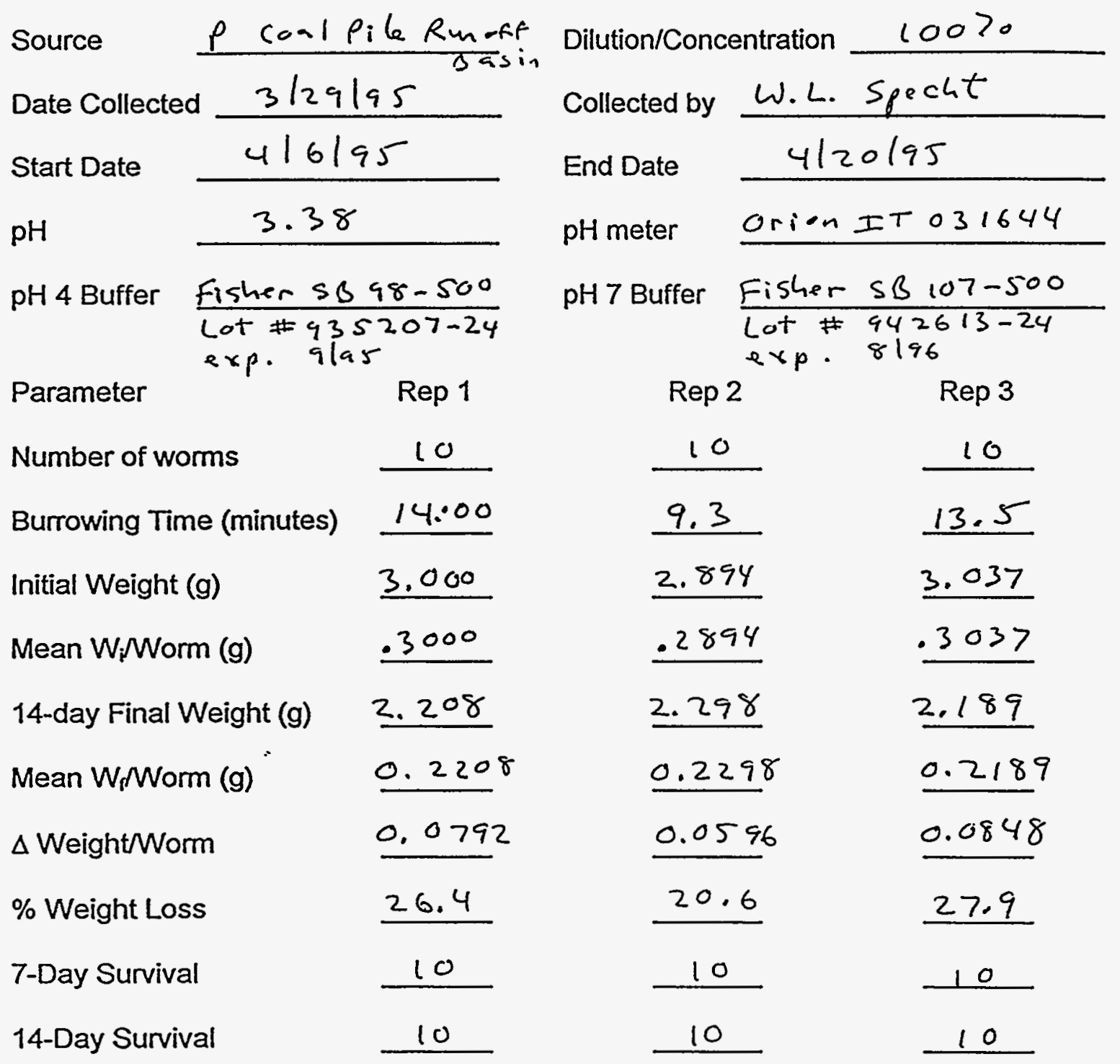

Notes/Observations:

7-day weens were all balled up together

between the side of the jas e the soil. 
EARTHWORM TOXICITY TESTING BENCH SHEET

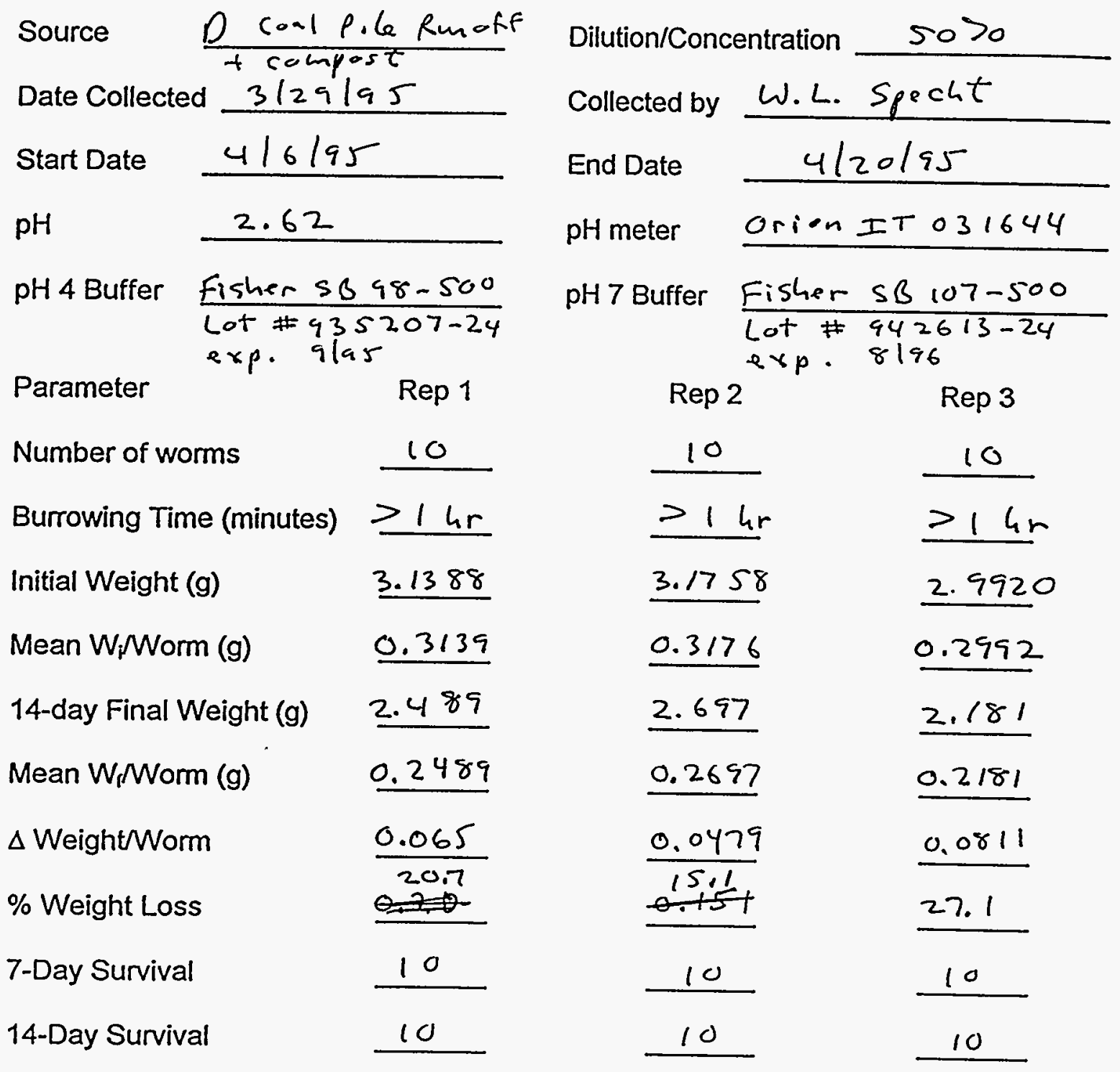

Notes/Observations:

7-day works were clumped together i, rep 1 on bottom; Rep 2 co side, against, glass: Rep 3 an top 
EARTHWORM TOXICITY TESTING BENCH SHEET

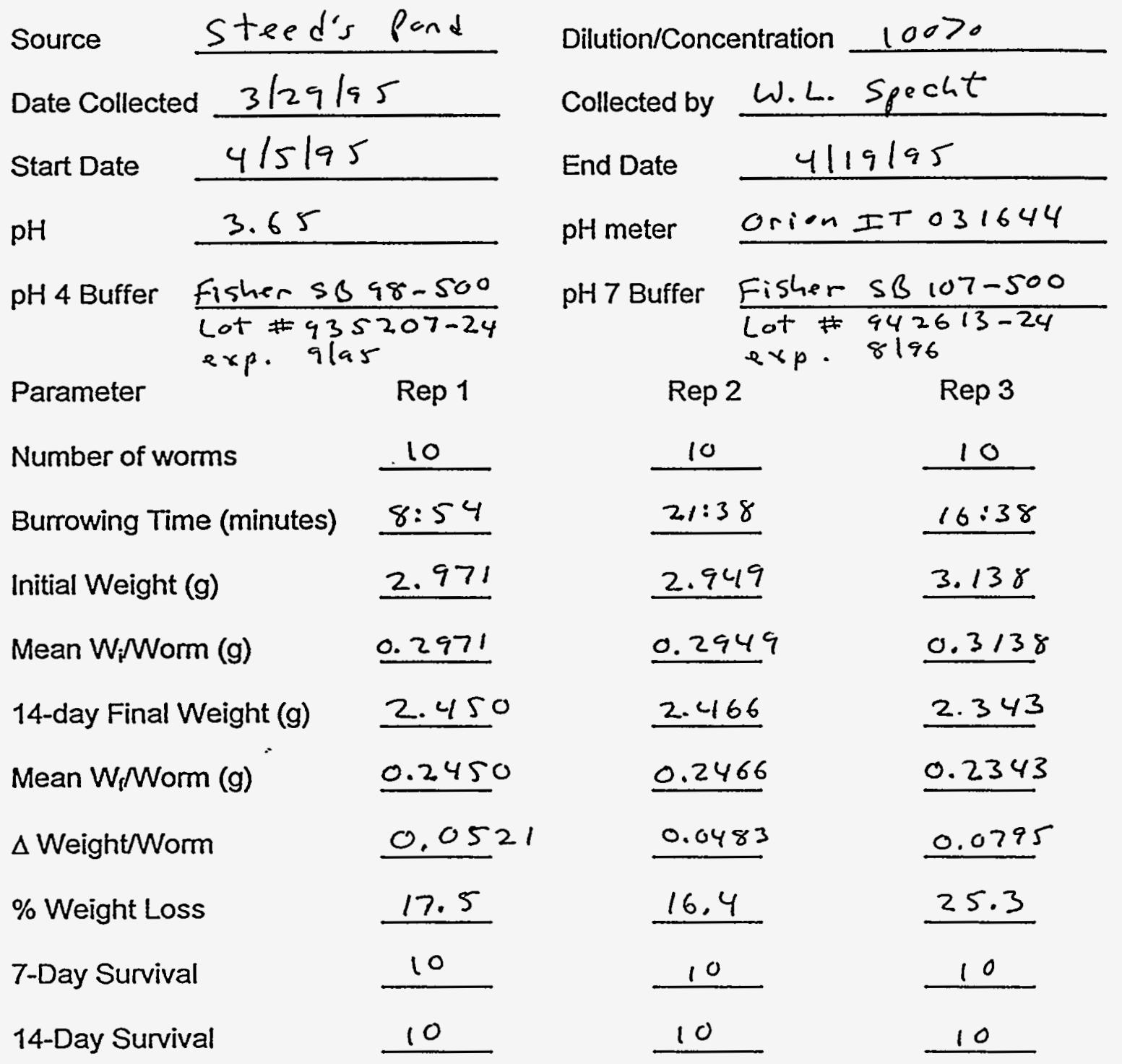

Notes/Observations:

7 -day - works were distributed evenly

14-duy - works were distributed every 


\section{EARTHWORM TOXICITY TESTING BENCH SHEET}

Source 2-chloracetain ide

Kodak lot 910478

Date Collected

Start Date 415195

$\mathrm{pH}$

6.19

pH 4 Buffer Fisher SB 98-500

Parameter exp. alas

Number of worms

Burrowing Time (minutes)

Initial Weight (g)

Mean WiNorm (g)

14-day Final Weight (g)

Mean Wr Worm (g)

$\Delta$ Weight/Worm

$\%$ Weight Loss

7-Day Survival

14-Day Survival
Dilution/Concentration $30 \mathrm{mg} / \mathrm{kg}$ Collected by W.L. Specht End Date $\quad 4119195$

pHmeter Orien ITO31644 pH7 Buffer $\frac{\text { Fisher SB } 107-500}{\text { Lot \#942613-24 }}$ exp. 8196 Rep 2

Rep 3

$\frac{10}{10: 55} \frac{10}{2.810} \quad \frac{4: 05}{3.161}$

$0.2810 \quad 0.3 / 61$

2.363

0.2363

2.642

0.2935 $0.26+2$ mfes

0.0447

0.0226

15.9

7.1

10

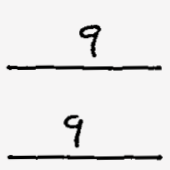

Notes/Observations:

$7-d a y$ warms are evenly distributed
$14-d-y$ worms evely distributed




\section{EARTHWORM TOXICITY TESTING BENCH SHEET}

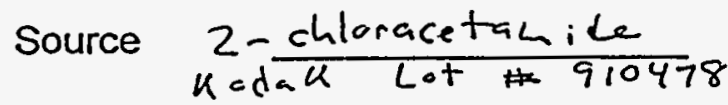
Date Collected

Start Date

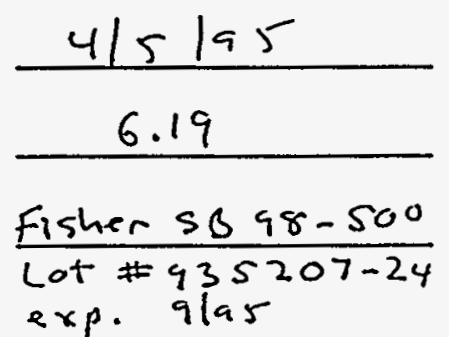

Parameter

Number of worms

Burrowing Time (minutes)

Initial Weight (g)

Mean WiNorm (g)

14-day Final Weight (g)

Mean WrWorm (g)

$\Delta$ Weight/Worm

$\%$ Weight Loss

7-Day Survival

14-Day Survival
Rep 1

10

8.0

3.223

0.3223

2.108

0.2635

0.0588

18.2

$\frac{8}{8}$

Dilution/Concentration $38.5 \mathrm{~ms} / \mathrm{Kg}$ Collected by W.L. Specht

End Date 4119195

$\mathrm{pH}$ meter

Orien IT 031644

pH 7 Buffer

$\frac{\text { Fisher SB } 107-500}{\text { Lot } 942613-24}$ exp. 8196

$\operatorname{Rep} 2$

Rep 3

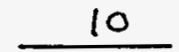

10

8.0

8.1

3.391

3.135

0.3391

0.3135

1.558

2.255

0.266

0.2819

0.0731

.0316

21.6

10.1

$\frac{6}{6}$

Notes/Observations:

\begin{tabular}{l}
$7-d y$ works evenly distributed \\
$14-d y-$ worns evely distributed \\
\hline
\end{tabular}


EARTHWORM TOXICITY TESTING BENCH SHEET

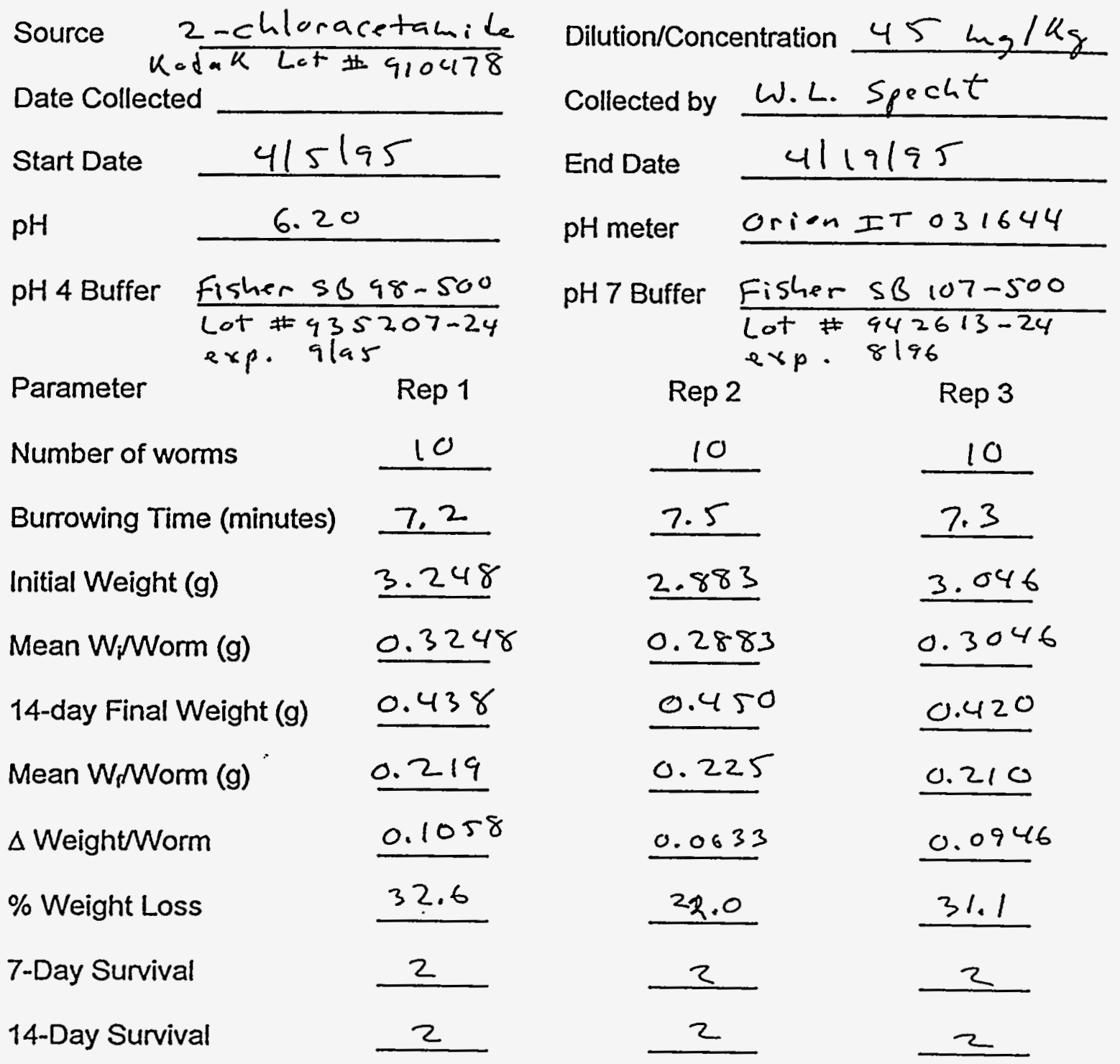

Notes/Observations: 


\section{EARTHWORM TOXICITY TESTING BENCH SHEET}

Source 2-chloracetamide $k$ ad $<$ lot 910478

Date Collected

Start Date

415195

$\mathrm{pH}$

$$
6.19
$$

pH 4 Buffer

$$
\begin{aligned}
& \text { Fisher s898-500 } \\
& \text { Lot \#935207-24 } \\
& \text { exp. 9las }
\end{aligned}
$$

Parameter

Rep 1

Number of worms

$$
10
$$

Burrowing Time (minutes)

8.5

Initial Weight (g)

2.786

Mean WiNorm (g)

0.2786

14-day Final Weight (g)

Mean WiNorm (g)

$\Delta$ Weight/Worm

$\%$ Weight Loss

7-Day Survival

14-Day Survival

Notes/Observations:

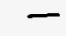

一

0
Dilution/Concentration $55 \mathrm{mg} / \mathrm{kg}$

Collected by W.L. Specht

End Date

$$
4119195
$$

$\mathrm{pH}$ meter

$$
\text { Orien IT O31644 }
$$

$\mathrm{pH} 7$ Buffer

$\frac{\text { Fisher SB } 107-500}{\text { Lot } \$ 42613-24}$

Rep 2

$\operatorname{Rep} 3$

10

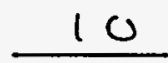

12.7

18.6

3.127

3.324

0.3127

0.3324
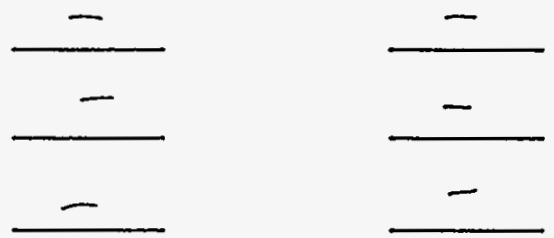

$\longrightarrow$
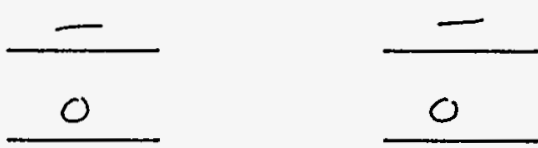

0

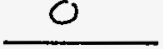

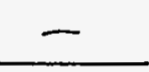

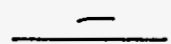




\section{APPENDIX 4}

Results of Mann-Whitney U Tests 
$\rightarrow$ TITLE 'Weight LOSS $\mathrm{M}-\mathrm{W}$ '

$\rightarrow$ SET LENGIH $=$ NONE.

$\rightarrow$ MISSING VALUES WTLOSS (99999).

$\rightarrow$ LIST VARTABLES $=$ ALL

456 bytes of memory required for the LIST procedure.

240 bytes have already been acquired.

216 bytes remain to be acquired.

24 Aug 95 Weight Loss M-W

Page 27

$\begin{array}{rrlrr}\text { REP } & \text { BURTTME UNITS } & \text { LOCATION } & \text { LOCCODE } & \text { WILOSS } \\ & & & & \\ 1.00 & 5.50 \text { Minutes } & \text { Compost } & 1.00 & 14.10 \\ 1.00 & 5.40 \text { Minutes } & \text { ArtSoil } & 2.00 & 15.10 \\ 1.00 & 60.00 \text { Minutes } & \text { DCOal } & 3.00 & 99999.00 \\ 1.00 & 14.00 \text { Minutes } & \text { PCoal } & 4.00 & 26.40 \\ 1.00 & 60.00 \text { Minutes } & \text { DCPR } & 5.00 & 20.70 \\ 1.00 & 8.90 \text { Minutes } & \text { Steeds } & 6.00 & 17.50 \\ 2.00 & 5.60 \text { Minutes } & \text { Compost } & 1.00 & 10.80 \\ 2.00 & 7.50 \text { Minutes } & \text { ArtSoil } & 2.00 & 14.80 \\ 2.00 & 60.00 \text { Minutes } & \text { DCoal } & 3.00 & 99999.00 \\ 2.00 & 9.30 \text { Minutes } & \text { PCoal } & 4.00 & 20.60 \\ 2.00 & 60.00 \text { Minutes } & \text { DCPR } & 5.00 & 15.10 \\ 2.00 & 21.60 \text { Minutes } & \text { Steeds } & 6.00 & 16.40 \\ 3.00 & 5.40 \text { Minutes } & \text { Compost } & 1.00 & 13.70 \\ 3.00 & 4.00 \text { Minutes } & \text { ArtSoil } & 2.00 & 20.90 \\ 3.00 & 60.00 \text { Minutes } & \text { DCOal } & 3.00 & 99999.00 \\ 3.00 & 13.50 \text { Minutes } & \text { PCOal } & 4.00 & 27.90 \\ 3.00 & 60.00 \text { Minutes } & \text { DCPR } & 5.00 & 27.10 \\ 3.00 & 16.60 \text { Minutes } & \text { Steeds } & 6.00 & 25.30\end{array}$

Number of cases read: 18 Number of cases listed: 18

24 Aug 95 Weight Loss $M-W$

Page 28

Preceding task required .00 seconds elapsed.

$\rightarrow$ NPAR TESTS $/ M-W=$ wtloss BY loccode $\left(\begin{array}{ll}1 & 2\end{array}\right)$.

$\star * * * *$ Workspace allows for 18724 cases for NPAR tests $* * * * *$ 
- - - - Mann-Whitney U - Wilcoxon Rank Sum W Test

WILOSS

by LOCCODE

Mean Rank Cases

$\begin{array}{rrl}2.00 & 3 & \text { LOCCODE }=1.00 \\ 5.00 & 3 & \text { LOCCODE }=2.00 \\ -- & \\ & 6 & \text { Total }\end{array}$

\begin{tabular}{ccccc} 
& & Exact & \multicolumn{2}{c}{ Corrected for ties } \\
$\mathrm{U}$ & $\mathrm{W}$ & 2-Tailed P & $\mathrm{Z}$ & 2-Tailed P \\
.0 & 6.0 & .1000 & -1.9640 & .0495
\end{tabular}

24 Aug 95 Weight Loss $\mathrm{M}-\mathrm{W}$

Page 30

Preceding task required .00 seconds elapsed.

$\rightarrow$ NPAR TESTS /M-W= wtloss BY loccode (1 3$)$.

$* * * * *$ Workspace allows for 18724 cases for NPAR tests $* * * * *$

24 Aug 95 Weight Loss M-W

Page 31

- - - - Mann-Whitney U - Wilcoxon Rank Sum W Test

WIIOSS

by LOCCODE

Mean Rank Cases

$$
\begin{array}{rrl}
2.00 & 3 & \text { LOCCODE }=1.00 \\
.00 & 0 & \text { LOCCODE }=3.00 \\
-- & \\
& 3 & \text { Total }
\end{array}
$$

This test cannot be performed on empty groups. 
Preceding task required 2.00 seconds elapsed.

$\rightarrow$ NPAR TESTS /M-W= wtloss BY loccode $\left(\begin{array}{ll}1 & 4\end{array}\right)$.

$* * * * *$ Workspace allows for 18724 cases for NPAR tests $* * * * *$

- - - - Mann-Whitney U - Wilcoxon Rank Sum W Test

WTLOSS

by IOCCODE

Mean Rank Cases

$\begin{array}{rrl}2.00 & \text { 3. } & \text { IOCCODE }=1.00 \\ 5.00 & 3 & \text { LOCCODE }=4.00 \\ -- & \\ 6 & \text { TotaI }\end{array}$

\begin{tabular}{ccccc} 
& & .Exact & \multicolumn{2}{c}{ Corrected for ties } \\
$\mathrm{U}$ & $\mathrm{W}$ & 2-Tailed P & $\mathrm{Z}$ & 2-Tailed P \\
.0 & 6.0 & .1000 & -1.9640 & .0495
\end{tabular}

24 Aug 95 Weight Loss M-W

Page 34

Preceding task required .00 seconds elapsed.

$\rightarrow$ NPAR TESTS $/ M-W=$ wtloss BY loccode $(15)$.

$\star * * * *$ Workspace allows for 18724 cases for NPAR tests $* * * * *$ 
- - - - Mann-Whitney U - Wilcoxon Rank Sum W Test

WILOSS

by IOCCODE

Mean Rank Cases

$\begin{array}{rrl}2.00 & 3 & \text { LOCCODE }=1.00 \\ 5.00 & 3 & \text { LOCCODE }=5.00 \\ & -- & \\ & 6 & \text { Total }\end{array}$

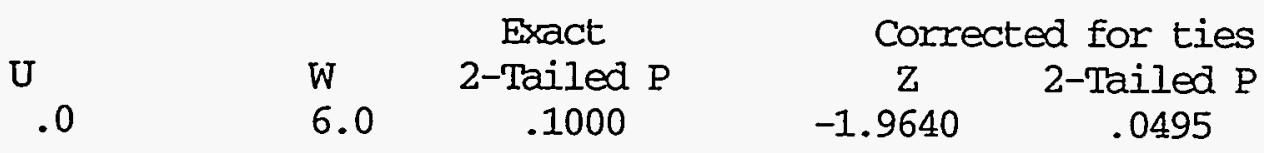

24 Aug 95 Weight Loss M-W

Page 36

Preceding task required 2.00 seconds elapsed.

$\rightarrow$ NPAR TESTS /M-W= wtloss BY loccode (1 6).

***** Workspace allows for 18724 cases for NPAR tests

24 Aug 95 Weight Loss $M-W$

Page 37

- - - - Mann-Whitney U - Wilcoxon Rank Sum W Test

WILOSS

by LOCCODE

Mean Rank Cases

2.00

3 LOCCODE $=1.00$

3 LOCCODE $=6.00$

5.00

6 Total

$\mathrm{U}$

.0

$\begin{array}{lc}\text { Exact } \\ \text { W } & \text { 2-Tailed P } \\ 6.0 & .1000\end{array}$

Corrected for ties

Z 2-Tailed P

$-1.9640 \quad .0495$ 

Preceding task required .00 seconds elapsed. 
$\rightarrow$ TITLE

$\rightarrow$ 'Burrowing time by Soil Type-MN' .

$\rightarrow$ SUBTITLE

$\rightarrow 1$ '

$\rightarrow$ SET LENGTH $=$ NONE.

$\rightarrow$ LIIST VARTABLES $=$ ALI

456 bytes of memory required for the LIST procedure.

240 bytes have already been acquired.

216 bytes remain to be acquired.

$\begin{array}{rrlrr}\text { REP } & \text { BURTIME UNITS } & \text { LOCATION } & \text { LOCCODE } & \text { WILOSS } \\ 1.00 & 5.50 \text { Minutes } & \text { Compost } & 1.00 & 14.10 \\ 1.00 & 5.40 \text { Minutes } & \text { ArtSoil } & 2.00 & 15.10 \\ 1.00 & 60.00 \text { Minutes } & \text { DCoal } & 3.00 & 99999.00 \\ 1.00 & 14.00 \text { Minutes } & \text { PCoal } & 4.00 & 26.40 \\ 1.00 & 60.00 \text { Minutes } & \text { DCPR } & 5.00 & 20.70 \\ 1.00 & 8.90 \text { Minutes } & \text { Steeds } & 6.00 & 17.50 \\ 2.00 & 5.60 \text { Minutes } & \text { Compost } & 1.00 & 10.80 \\ 2.00 & 7.50 \text { Minutes } & \text { ArtSoil } & 2.00 & 14.80 \\ 2.00 & 60.00 \text { Minutes } & \text { DCoal } & 3.00 & 99999.00 \\ 2.00 & 9.30 \text { Minutes } & \text { PCoal } & 4.00 & 20.60 \\ 2.00 & 60.00 \text { Minutes } & \text { DCPR } & 5.00 & 15.10 \\ 2.00 & 21.60 \text { Minutes } & \text { Steeds } & 6.00 & 16.40 \\ 3.00 & 5.40 \text { Minutes } & \text { COMpost } & 1.00 & 13.70 \\ 3.00 & 4.00 \text { Minutes } & \text { ArtSoil } & 2.00 & 20.90 \\ 3.00 & 60.00 \text { Minutes } & \text { DCoal } & 3.00 & 99999.00 \\ 3.00 & 13.50 \text { Minutes } & \text { PCoal } & 4.00 & 27.90 \\ 3.00 & 60.00 \text { Minutes } & \text { DCPR } & 5.00 & 27.10 \\ 3.00 & 16.60 \text { Minutes } & \text { Steeds } & 6.00 & 25.30\end{array}$

Number of cases read: 18 Number of cases listed: 18

24 Aug 95 Burrowing time by Soil Type-MN

Preceding task required .00 seconds elapsed.

-> MISSING VALUES ALL (99999).

>Error \#4808 in column 16. Text: UNITS 
>Missing values are not available for long string variables. $>$ This command not executed.

$\rightarrow$ NPAR TESTS /M-W= burtime BY loccode $\left(\begin{array}{ll}1 & 2\end{array}\right)$.

**** Workspace allows for 18724 cases for NPAR tests

24 Aug 95 Burrowing time by Soil Type-MN

Page 11

- - - - Mann-Whitney U - Wilcoxon Rank Sum W Test

BURTIME

by LOCCODE

Mean Rank Cases

$\begin{array}{lrl}3.83 & 3 & \text { IOCCODE }=1.00 \\ 3.17 & 3 & \text { LOCCODE }=2.00 \\ & -- & \\ & 6 & \text { Total }\end{array}$

\begin{tabular}{ccccc} 
& & Exact & \multicolumn{2}{c}{ Corrected for ties } \\
U & W & 2-Tailed P & Z & 2-Tailed P \\
3.5 & .11 .5 & .7000 & -.4428 & .6579
\end{tabular}

24 Aug 95 Burrowing time by Soil Type-MN

Page 12

Preceding task required .00 seconds elapsed.

$\rightarrow$ NPAR TESTS /M-W= burtime BY loccode(l 3$)$.

***** Workspace allows for 18724 cases for NPAR tests $* * * * *$

24 Aug 95 Burrowing time by Soil Type-MN

Page 13

- - - - Mann-Whitney U - Wilcoxon Rank Sum W Test

BURTTME

by LOCCODE 
Mean Rark Cases
2.00
3 LOCCODE $=1.00$
5.00
3 LOCCODE $=3.00$
6 Total

\begin{tabular}{|c|c|c|c|}
\hline & & Exact & Corrected for ties \\
\hline$U$ & W & 2-Tailed P & 2-Tailed P \\
\hline .0 & 6.0 & .1000 & -2.0868 \\
\hline
\end{tabular}

24 Aug 95 Burrowing time by Soil Type-MN

Page 14

Preceding task required 1.00 seconds elapsed.

$\rightarrow$ NPAR TESTS $/ M-W=$ burtime BY loccode $\left(\begin{array}{ll}1 & 4\end{array}\right)$.

***** Workspace allows for 18724 cases for NPAR tests $* * * * *$

24 Aug 95 Burrowing time by Soil Type-MN

- - - - Mann-Whitney U - Wilcoxon Rank Sum W Test

BURTTME

by LOCCODE

Mean Rank Cases

$\begin{array}{rrl}2.00 & 3 & \text { IOCCODE }=1.00 \\ 5.00 & 3 & \text { LOCCODE }=4.00 \\ -- & \\ & 6 & \text { Total }\end{array}$

\begin{tabular}{ccccc} 
& & Exact & \multicolumn{2}{c}{ Corrected for ties } \\
U & W & 2-Tailed $P$ & \multicolumn{2}{c}{ 2-Tailed P } \\
.0 & 6.0 & .1000 & -1.9640 & .0495
\end{tabular}

24 Aug 95 Burrowing time by Soil Type-MN

Page 16

Preceding task required 1.00 seconds elapsed. 
$\rightarrow$ NPAR TESTS $/ M-W=$ burtime BY loccode (1 5).

***** Workspace allows for 18724 cases for NPAR tests

24 Aug 95 Burrowing time by Soil Type-MN

- - - - Mann-Whitney U - Wilcoxon Rank Sum W Test

BURITIME

by LOCCODE

Mean Rank Cases

$\begin{array}{rrl}2.00 & 3 & \text { LOCCODE }=1.00 \\ 5.00 & 3 & \text { LOCCODE }=5.00 \\ -- & \\ & 6 & \text { Total }\end{array}$

\begin{tabular}{ccccc} 
& & Exact & \multicolumn{2}{c}{ Corrected for ties } \\
$\mathrm{U}$ & $\mathrm{W}$ & 2-Tailed P & $\mathrm{Z}$ & 2-Tailed P \\
.0 & 6.0 & .1000 & -2.0868 & .0369
\end{tabular}

24 Aug 95 Burrowing time by Soil Type-MN

Page 18

Preceding task required 1.00 seconds elapsed.

$\rightarrow$ NPAR TESTS $/ M-W=$ burtime BY loccode $(16)$.

***** Workspace allows for 18724 cases for NPAR tests

24 Aug 95 Burrowing time by Soil Type-MN

Page 19

- - - - Mann-Whitney U - Wilcoxon Rank Sum W Test

BURTTME

bY LOCCODE

Mean Rank Cases

2.003 LOCCODE $=1.00$

5.003 LOCCODE $=6.00$ 


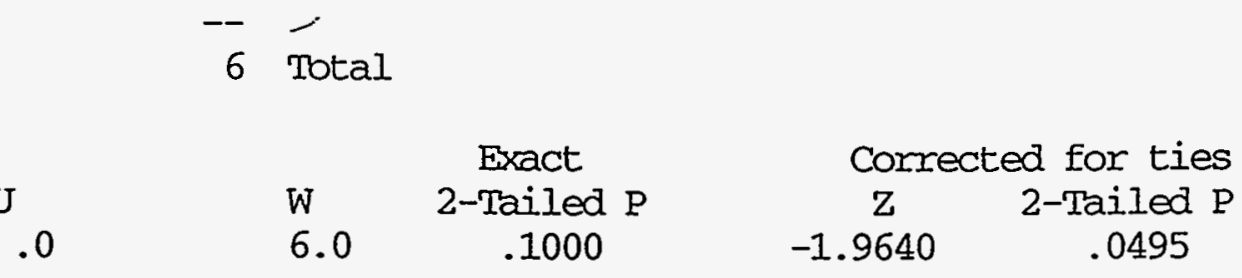

24 Aug 95 Burrowing time by Soil Type-MN

Page 20

Preceding task required .00 seconds elapsed.

$\rightarrow$ NPAR TESTS $/ M-W=$ burtime BY loccode $(22)$.

$* * \star \star *$ Workspace allows for 18724 cases for NPAR tests

24 Aug 95 Burrowing time by Soil Type-MN

Page 21

- - - - Mann-Whitney U - Wilcoxon Rank Sum W Test

BUTRTME

by IOCCODE

Mean Rank Cases

$$
\begin{array}{rrl}
2.00 & 3 & \text { LOCCODE }=2.00 \\
.00 & 0 & \text { LOCCODE }=2.00 \\
& -- & \\
& 3 & \text { Total }
\end{array}
$$

This test cannot be performed on empty groups.

24 Aug 95 Burrowing time by Soil Type-MN

Page 22

Preceding task required 2.00 seconds elapsed.

$\rightarrow$ NPAR TESTS $\quad / M-W=$ burtime BY loccode $(23)$.

***** Workspace allows for 18724 cases for NPAR tests $* * * * *$ 
- - - - Mann-Whitney U - Wilcoxon Rank Sum W Test

by LOCCODE

Mean Rank Cases

$2.00 \quad 3$ LOCCODE $=2.00$

5.003 LOCCODE $=3.00$

6 Total

\begin{tabular}{ccccc} 
& & Exact & \multicolumn{2}{c}{ Corrected for ties } \\
$\mathrm{U}$ & $\mathrm{W}$ & 2-Tailed P & $\mathrm{Z}$ & 2-Tailed P \\
.0 & 6.0 & .1000 & -2.0868 & .0369
\end{tabular}

24 Aug 95 Burrowing time by Soil Type-MN

Page 24

Preceding task required..00 seconds elapsed.

$\rightarrow$ NPAR TESTS /M-W= buntime BY loccode $(24)$.

***** Workspace allows for 18724 cases for NPAR tests

24 Aug 95 Burrowing time by Soil Type-MN

Page 25

- - - - Mann-Whitney U - Wilcoxon Rank Sum W Test

BURTIIME

by LOCCODE

Mean Rank Cases

$\begin{array}{rrl}2.00 & 3 & \text { LOCCODE }=2.00 \\ 5.00 & 3 & \text { LOCCODE }=4.00 \\ -- & \\ & 6 & \text { Total }\end{array}$

Exact

Corrected for ties 


$\begin{array}{ccccc}U & W & \text { 2-Tailed } P & Z & \text { 2-Tailed P } \\ .0 & 6.0 & .1000 & -1.9640 & .0495\end{array}$

24 Aug 95 Burrowing time by Soil Type-MN

Page 26

Preceding task required .00 seconds elapsed.

$\rightarrow$ NPAR TESTS $/ M-W=$ burtime BY loccode(2 5).

***** Workspace allows for 18724 cases for NPAR tests

24 Aug 95 Burrowing time by Soil Type-MW

Page 27

- - - - - Mann-Whitney U - Wilcoxon Rank Sum W Test

BURTTME

by IOCCODE

Mean Rank Cases
2.00
3 LOCCODE $=2.00$
5.00
3 LOCCODE $=5.00$
6 Total
Exact
$6.0 \quad .1000$
Corrected for ties
$\mathrm{Z}$ 2-Tailed P
$-2.0868 \quad .0369$

24 Aug 95 Burrowing time by Soil Type-MN

Page 28

Preceding task required 2.00 seconds elapsed.

$\rightarrow$ NPAR TESTS /M-W= burtime BY loccode $(26)$.

$\star * * * *$ Workspace allows for 18724 cases for NPAR tests $* * * * *$ 
- - - - Mann-Whitney U - Wilcoxon Rank Sum W Test

BURTIME

by LOCCODE

Mean Rank Cases

$\begin{array}{rrl}2.00 & 3 & \text { LOCCODE }=2.00 \\ 5.00 & 3 & \text { LOCCODE }=6.00 \\ -- & \\ & 6 & \text { Total }\end{array}$

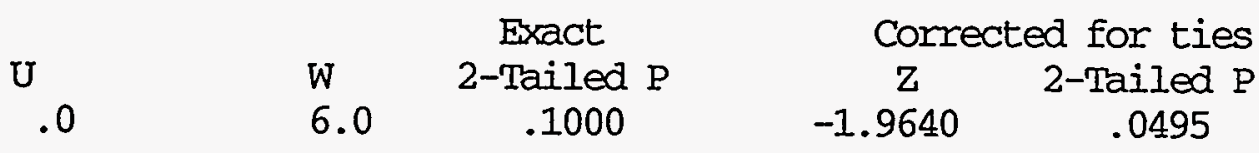

24 Aug 95 Burrowing time by Soil Type-MN

Page 30

Preceding task required .00 seconds elapsed.

$\rightarrow$ NPAR TESTS /M-W= burtime BY loccode $\left(\begin{array}{ll}3 & 3\end{array}\right)$.

$\star * * * *$ Workspace allows for 18724 cases for NPAR tests $* * * * *$

24 Aug 95 Burrowing time by Soil Type-MN

Page 31

- - - - Mann-Whitney U - Wilcoxon Rank Sum W Test

BURTIME

by LOCCODE

Mean Rank Cases

$$
\begin{array}{rrl}
2.00 & 3 & \text { LOCCODE }=3.00 \\
.00 & 0 & \text { LOCCODE }=3.00 \\
-- & \\
& 3 & \text { Total }
\end{array}
$$

This test cannot be performed on empty groups. 
Preceding task required .00 seconds elapsed.

$\rightarrow$ NPAR TESTS /M-W $=$ burtime BY loccode $(34)$.

$* * * * *$ Workspace allows for 18724 cases for NPAR tests $* * * * *$

24 Aug 95 Burrowing time by Soil Type-MN

Page 33

- - - - Mann-Whitney U - Wilcoxon Rank Sum W Test

BURTTME

by IOCCODE

Mean Rank Cases

$5.00 \quad 3$ LOCCODE $=3.00$

2.003 LOCCODE $=4.00$

6. Total

\begin{tabular}{ccccc} 
& & Exact & \multicolumn{2}{c}{ Corrected for ties } \\
$\mathrm{U}$ & $\mathrm{W}$ & 2-Tailed $\mathrm{P}$ & $\mathrm{Z}$ & 2-Tailed P \\
.0 & 15.0 & .1000 & -2.0868 & .0369
\end{tabular}

24 Aug 95 Burrowing time by Soil Type-MN

Page 34

Preceding task required .00 seconds elapsed.

$\rightarrow$ NPAR TESTS /M-W= burtime BY loccode $(35)$

***** Workspace allows for 18724 cases for NPAR tests $* * * * *$ 
BURTIME

by LOCCODE

Mean Rank Cases

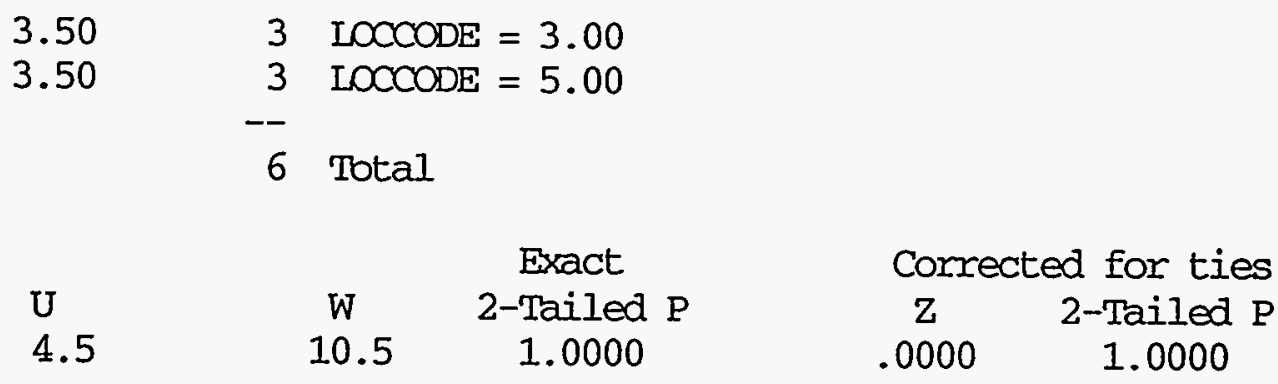

24 Aug 95 Burrowing time by Soil Type-MN

Page 36

Preceding task required 1.00 seconds elapsed.

$\rightarrow$ NPAR TESTS $/ M-W=$ burtime BY loccode $(36)$.

$\star \star \star \star *$ Workspace allows for 18724 cases for NPAR tests

24 Aug 95 Burrowing time by Soil Type-MN

Page 37

- - - - Mann-Whitney U - Wilcoxon Rank Sum W Test

BURTIME

by LOCCODE

Mean Rank Cases

$\begin{array}{rrl}5.00 & 3 & \text { LOCCODE }=3.00 \\ 2.00 & 3 & \text { LOCCODE }=6.00 \\ & -- & \\ & 6 & \text { Total }\end{array}$

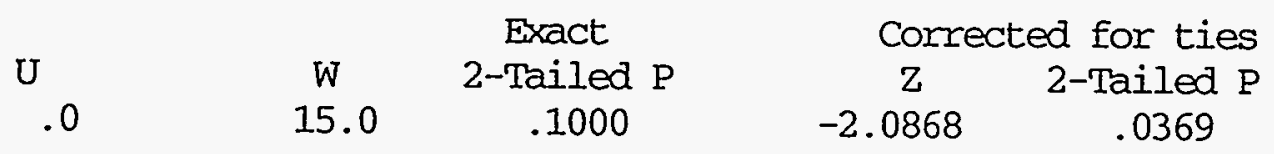


Preceding task required 1.00 seconds elapsed.

$\rightarrow$ NPAR TESTS /M-W= burtime BY loccode $(44)$.

$* * * * *$ Workspace allows for 18724 cases for NPAR tests $* * * * *$

24 Aug 95 Burrowing time by Soil Type-MN

Page 39

- - - - Mann-Whitney U - Wilcoxon Rank Sum W Test

BURTIME

by LOCCODE

Mean Rank Cases

$\begin{array}{rrl}2.00 & 3 & \text { LOCCODE }=4.00 \\ .00 & 0 & \text { LOCCODE }=4.00 \\ -- & \\ & 3 & \text { Total }\end{array}$

This test cannot be performed on empty groups.

24 Aug 95 Burrowing time by Soil Type-MN

Page 40

Preceding task required .00 seconds elapsed.

$\rightarrow$ NPAR TESTS /M-W= burtime BY loccode $(45)$.

***** horkspace allows for 18724 cases for NPAR tests $* * * * *$

24 Aug 95 Burrowing time by Soil Type-MN

Page 41

- - - - Mann-Whitney U - Wilcoxon Rank Sum W Test

BURTIME

by LOCCODE 
Mean Rank Cases

$\begin{array}{rrl}2.00 & 3 & \text { LOCCODE }=4.00 \\ 5.00 & 3 & \text { LOCCODE }=5.00 \\ -- & \\ & 6 & \text { Total }\end{array}$

\begin{tabular}{ccccc} 
& & Exact & \multicolumn{2}{c}{ Corrected for ties } \\
$\mathrm{U}$ & $\mathrm{W}$ & 2-Tailed P & $\mathrm{Z}$ & 2-Tailed P \\
.0 & 6.0 & .1000 & -2.0868 & .0369
\end{tabular}

24 Aug 95 Burrowing time by Soil Type-MN

Page 42

Preceding task required 1.00 seconds elapsed.

$\rightarrow$ NPAR TESTS /M-W= burtime BY Ioccode (4 6).

**** Workspace allows for 18724 cases for NPAR tests

24 Aug 95 Burrowing time by Soil Type-MN

Page 43

- - - - Mann-Whitney Uं - Wilcoxon Rank Sum W Test

BURTTME

by LOCCODE

Mean Rank Cases

$\begin{array}{rrl}3.00 & 3 & \text { LOCCODE }=4.00 \\ 4.00 & 3 & \text { LOCCODE }=6.00 \\ -- & \\ & 6 & \text { Total }\end{array}$

\begin{tabular}{ccccc} 
& & Exact & \multicolumn{2}{c}{ Corrected for ties } \\
$\mathrm{U}$ & W & 2-Tailed P & $\mathrm{Z}$ & 2-Tailed P \\
3.0 & 9.0 & .7000 & -.6547 & .5127
\end{tabular}

24 Aug 95 Burrowing time by Soil Type-MW

Page 44

Preceding task required .00 seconds elapsed. 


\section{$\rightarrow$ NPAR TESTS /M-W= burtime BY loccode(5 5).}

$\star * * * *$ Workspace allows for 18724 cases for NPAR tests $* * * * *$

- - - - Mann-Whitney U - Wilcoxon Rank Sum W Test

$$
\text { by IOCCODE }
$$

Mean Rank Cases

$$
\begin{array}{rrl}
2.00 & 3 & \text { LOCCODE }=5.00 \\
.00 & 0 & \text { IOCCODE }=5.00 \\
-\frac{3}{3} & \text { Total }
\end{array}
$$

This test cannot be performed on empty groups.

Preceding task required .00 seconds elapsed.

$\rightarrow$ NPAR TESIS /M-W= burtime BY loccode $(56)$.

$* * * * *$ workspace allows for 18724 cases for NPAR tests $* * * * *$

- - - - Mann-Whitney U - Wilcoxon Rank Sum W Test

BUTRTIME

by LOCCODE

Mean Rank Cases
5.00
3 LOCCODE $=5.00$
2.00
3 LOCCODE $=6.00$ 
6 Total

$\mathrm{U}$

.0
W

15.0
Exact

2-Tailed P .1000
Corrected for ties

$\mathrm{Z}$

$-2.0868 \quad .0369$

24 Aug 95 Burrowing time by Soil Type-MN

Preceding task required 1.00 seconds elapsed. 


\section{APPENDIX 5}

Metal Concentrations in Test Soils and Earthworms 


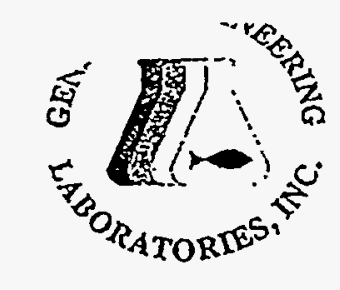

\title{
GENERAL ENGINEERING LABORATORIES
}

Meeting today's needs with a vision for tonorrow.

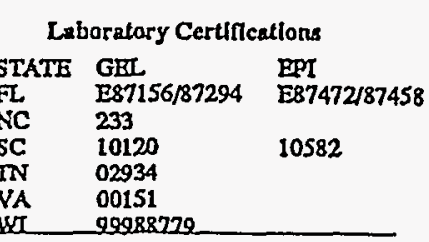

\section{CERTIFICATE OF ANALYSIS}

\author{
Client: Westinghouse Savannah River Co. \\ EPD-Building 773-58A \\ Aiken, South Caroline 29808-0001 \\ Contact: Mr. Bob Craig \\ Project Description: Analytical Services for SRS Environmental Characterization
}

cc: WSRC00193

Report Date: September 01, 1995

- Page 1 of 2

$\begin{array}{ll}\text { Sample ID } & : \text { ARTS } \\ \text { Lab ID } & : 9508156-04 \\ \text { Matrix } & : \text { Soil } \\ \text { Date Collected } & : 07 / 20 / 95 \\ \text { Date Received } & : 08 / 02 / 95 \\ \text { Priority } & : \text { Routine } \\ \text { Collector } & : \text { Client }\end{array}$

\begin{tabular}{|c|c|c|c|c|c|c|c|c|c|}
\hline Parameter & Qualfier & Result & DL & RL Units & $\mathrm{DF}$ & Analyst Date & Time & Batch & $\bar{M}$ \\
\hline \multicolumn{10}{|l|}{ Metals Analysls } \\
\hline Silver & $\mathbf{U}$ & -154 & 60.5 & 60.5 UGKG & 1.0 & NRM 08/24/95 & 1857 & 71530 & 1 \\
\hline Aluminum & & 1490000 & 289 & 486 UGKG & 1.0 & & & & \\
\hline Arsenic & & 2660 & 45.2 & 122 UGKG & 1.0 & & & & \\
\hline Barium & & 19800 & 1.61 & 72.9 UGKG & 1.0 & & & & \\
\hline Beryllium & & 138 & 0.277 & 72.9 UGKG & 1.0 & & & & \\
\hline Calcium & & 1470000 & 486 & 486 UGKG & 1.0 & & & & \\
\hline Cadmiurn & & 105 & 2.36 & 48.6 UGKG & 1.0 & & & & \\
\hline Cobsilt & & 204 & 4.28 & 97.2 UGKG & 1.0 & & & & \\
\hline Chromium & & 5000 & 14.5 & 97.2 UGKG & 1.0 & & & & \\
\hline Copper & & 2410 & 13.1 & 97.2 UGKG & 1.0 & & & & \\
\hline Iron & & 2070000 & 245 & 437 UGKG & 1.0 & & & & \\
\hline Potassium & & 27800 & 256 & 12200 UGKG & 1.0 & & & & \\
\hline Magnesium & & 70700 & 57.1 & 486 UaKG & 1.0 & & & & \\
\hline Manganese & & 5770 & 2.34 & 48.6 UGKG & 1.0 & & & & \\
\hline Sodium & & 9730 & 379 & 2430 UGKG & 1.0 & & & & \\
\hline Nickel & & 461 & 19.6 & 243 UGKG & 1.0 & & & & \\
\hline Lead & & 2650 & 27.5 & 122 UaKa & 1.0 & & & & $\therefore$ \\
\hline Antimony & $\mathbf{U}$ & -62.4 & 23.3 & 122 UaKG & 1.0 & & & & \\
\hline Selenium & $U$ & -75.1 & 34.7 & 122 UGKa & 1.0 & & & & . \\
\hline Thallium & U & -446 & 101 & 243 UGKG & 2.0 & NRM 08/24/95 & 2328 & 71530 & 1 \\
\hline Uranium by ICP & $\mathrm{U}$ & -3930 & 293 & 972 UGKO & 2.0 & & & & \\
\hline Vanadium & & 10400 & 5.69 & 243 UGKG & 1.0 & NRM $08 / 24 / 95$ & 1857 & 71530 & 1 \\
\hline Zine & & 2510 & 65.6 & 122 UGKG & 1.0 & & & & \\
\hline
\end{tabular}

The following prep procedures were performed:

TRACE 


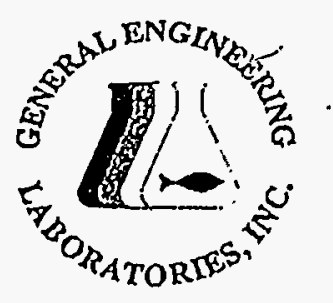

\section{GENERAL ENGINEERING LABORATORIES}

Meeting today's needs with a vision for tomorrow.

CERTIFICATE OF ANALYSIS

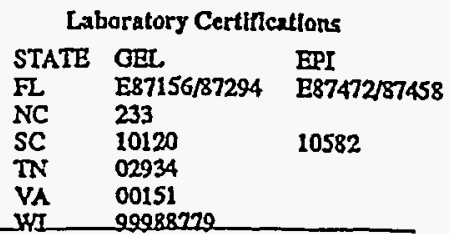

Client: Westinghouse Savannah River Co.

EPD-Building 773-58A

Aikon, South Carolina 29808-0001

Contact: Mr. Bob Craig

Project Description: Analytical Services for SRS Environmental Characterization

cc: WSRC00193

Report Datc: September 01, 1995

Page 1 of 2

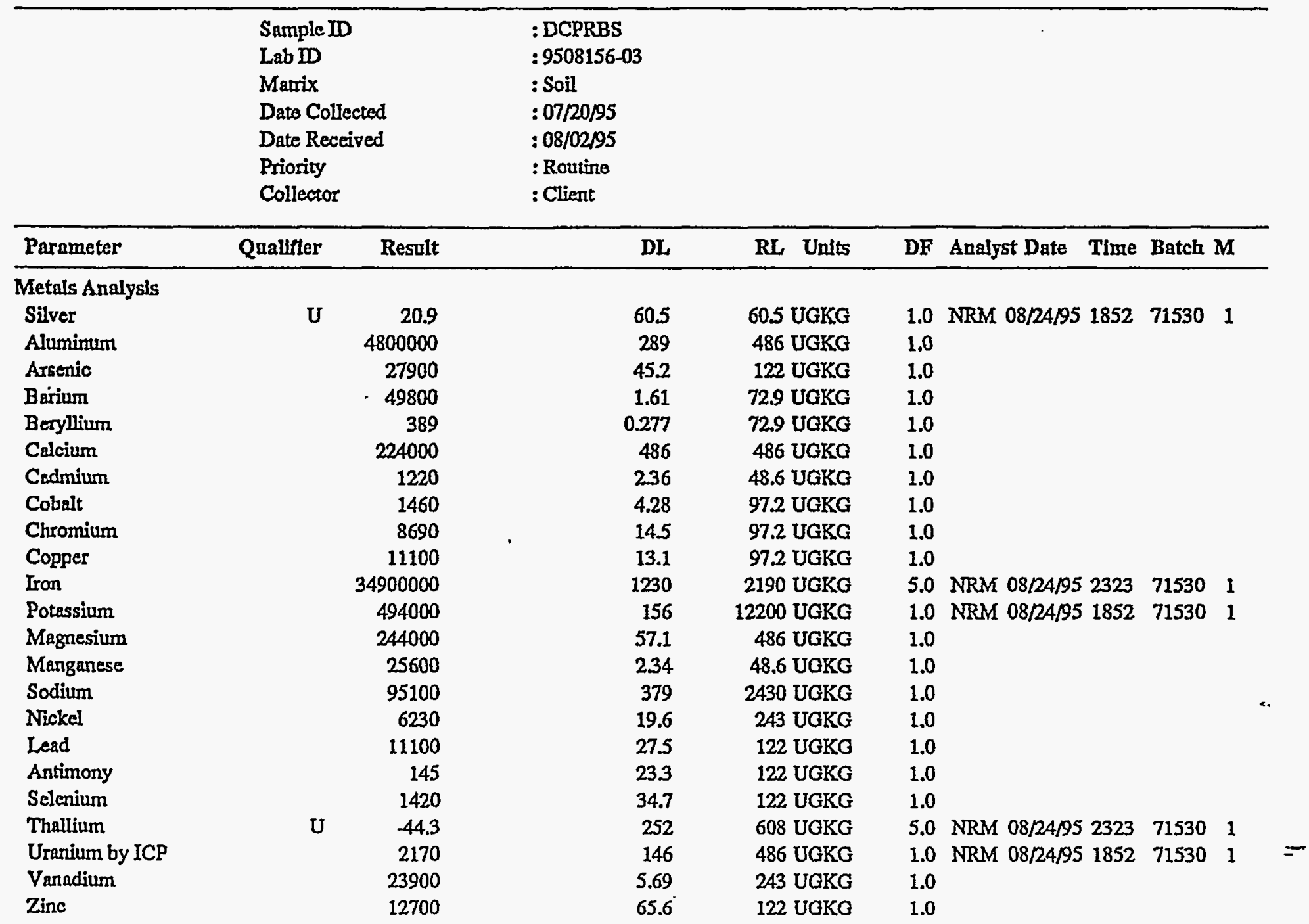

The following prep procedures were performed:

TRACE 


\section{GENERAL ENGINEERING LABORATORIES}

Meeting today's needs with a vision for tomorrow.

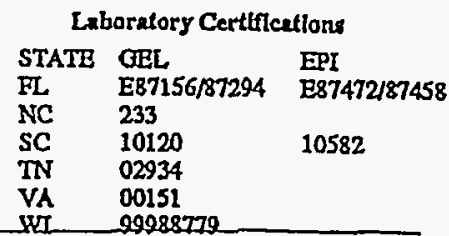

\section{CERTIFICATE OF ANALYSIS}

Client: Westinghouse Savannah River Co.

EPD-Building 773-58A

Aiken, South Carolina 29808-0001

Contact: Mr. Bob Craig

Project Description: Analytical Services for SRS Environmental Characterization

$\propto:$ WSRC00193

Report Date: September 01، 1995

Page 1 of 2

$\begin{array}{ll}\text { Sample ID } & : \text { PCPRBS } \\ \text { Lab ID } & : 9508156-02 \\ \text { Matrix } & : \text { Soil } \\ \text { Date Collected } & : 07 / 20 / 95 \\ \text { Date Received } & : 08 / 02 / 95 \\ \text { Priority } & \text { : Routine } \\ \text { Collector } & \text { : Client }\end{array}$

\begin{tabular}{|c|c|c|}
\hline Parameter & Qualifier & Result \\
\hline \multicolumn{3}{|l|}{ Metals Analysis } \\
\hline Silvet & $U$ & -3.2 \\
\hline Aluminum & & 602000 \\
\hline Arsenic & & 1290 \\
\hline Barium & & . 4890 \\
\hline Beryllium & & 120 \\
\hline Calcium & & 380000 \\
\hline Cadmium & & 4 \\
\hline Cobalt & & 299 \\
\hline Chromium & & 1410 \\
\hline Copper & & 1660 \\
\hline Iron & & 1270000 \\
\hline Potassium & & 1400 \\
\hline Magnesium & & 10000 \\
\hline Manganese & & 85 \\
\hline Sodium & & 685 \\
\hline Nickel & & 69 \\
\hline Lead & & \\
\hline Antimony & & 2 \\
\hline Seleruium & & 201 \\
\hline Thallium & U & -1 \\
\hline Uranium by ICP & & 13 \\
\hline Vanadium & & 325 \\
\hline Zinc & & 75 \\
\hline
\end{tabular}

The following prep procedures were performed:

TRACE

FGD $\quad 08 / 23 / 95 \quad 1730 \quad 71530 \quad 2$ 


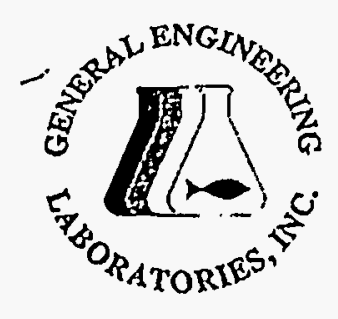

\section{GENERAL ENGINEERING LABORATORIES}

Meering today's needs with a vision for tomorrow.

\begin{tabular}{lll}
\multicolumn{3}{c}{ Laboratory Certificullons } \\
STATE & GEL & EPI \\
FL & E87156/87294 & E87472/87458 \\
NC & 233 & \\
SC & 10120 & 10582 \\
IN & 02934 & \\
VA & 00151 & \\
WI & 99988779 & \\
\hline
\end{tabular}

CERTIFICATE OF ANALYSIS

$\begin{array}{cl}\text { Client: } & \text { Westinghouse Savannah River Co. } \\ & \begin{array}{l}\text { EPD-Building 773-58A } \\ \text { Aiken, South Carolina 29808-0001 }\end{array} \\ \text { Contact: } & \text { Mr. Bob Craig } \\ \text { Analytical Services for SRS Environmental Characterization }\end{array}$

Project Description: Analytical Services for SRS Environmental Characterization

cc: WSRC00193

Report Date: September 01, 1995

Page 1 of 2

\begin{tabular}{|c|c|c|c|c|c|c|c|c|c|c|c|}
\hline & $\begin{array}{l}\text { Sample I } \\
\text { Lab ID } \\
\text { Marrix } \\
\text { Dato Col } \\
\text { Date Rec } \\
\text { Priority } \\
\text { Collecto }\end{array}$ & ived & & $\begin{array}{l}\text { : STEDS } \\
\text { : 9508156-20 } \\
\text { : Soil } \\
\text { : 07/20/95 } \\
\text { : 08/02995 } \\
\text { : Routine } \\
\text { : Client }\end{array}$ & & & & & & & \\
\hline Parameter & Quallfier & Result & & DL & RL Units & DF & Analyst Date & Time & Batch & $\mathbf{M}$ & \\
\hline \multicolumn{12}{|l|}{ Metals Analysls } \\
\hline Silver & & 10900 & & 59.8 & 59.8 UGKG & 1.0 & NRM 08/2A/95 & 2025 & 71530 & 1 & \\
\hline Aluminum & & 29700000 & & 1430 & 2400 UGKG & 5.0 & NRM 08/24/95 & 2349 & 71530 & 1 & \\
\hline Arsenic & & 17500 & & 44.6 & 120 UGKG & 1.0 & NRM 08/24AS & 2025 & 71530 & 1 & \\
\hline Barium & & 99600. & & 1.59 & 72.0 UGKG & 1.0 & & & & & \\
\hline Beryllium & & 750 & & 0.274 & 72.0 UGKG & 1.0 & & & & & \\
\hline Calcium & & 142000 & & 480 & 480 UGKG & 1.0 & & & & & \\
\hline Cadmium & & 1220 & & 2.33 & 48.0 UGKG & 1.0 & & & & & \\
\hline Cobalt & & 3700 & & 4.22 & 96.0 UGKG & 1.0 & & & & & \\
\hline Chromium & & 98000 & & 14.3 & 96.0 UGKG & 1.0 & & & & & \\
\hline Copper & & 51500 & - & 12.9 & 96.0 UGKG & 1.0 & & & & & \\
\hline Iron & & 33700000 & & 1210 & 2160 UGKG & 5.0 & NRM 08/24/95 & 2349 & 71530 & 1 & \\
\hline Potassium & & 200000 & & 154 & 12000 UGKG & 1.0 & NRM 08/24/95 & 52025 & 71530 & 1 & \\
\hline Magnesium & & 241000 & & 56.4 & 480 UGKG & 1.0 & & & & & \\
\hline Manganeso & & 141000 & & 2.31 & 48.0 UGKG & 1.0 & & & & & \\
\hline Sodium & & 36000 & & 374 & 2400 UGKG & 1.0 & & & & & \\
\hline Nickel & & 745000 & & 96.8 & 1200 UGKG & 5.0 & NRM 08/24/95 & 52349 & 71530 & 1 & $\alpha$ \\
\hline Lead & & 47500 & & 27.1 & 120 UGKG & 1.0 & NRM 08/24/95 & 52025 & 71530 & 1 & \\
\hline Antimony & & 373 & & 23.0 & 120 UGKG & 1.0 & & & & & \\
\hline Selenium & & 750 & & 34.3 & 120 UGKG & 1.0 & & & & & \\
\hline Thallium & $\mathrm{U}$ & -329 & & 248 & 600 UGKO & 5.0 & NRM 08/24/95 & 52349 & 71530 & 1 & \\
\hline Uranium by ICP & & 2140000 & & 722 & 2400 UGKG & 5.0 & & & & & \\
\hline Vanadium & & 73700 & & 5.62 & 240 UGKG & 1.0 & NRM 08/24/95 & 2025 & 71530 & 1 & \\
\hline Zinc & & 55500 & & 64.8 & 120 UGKG & 1.0 & & & & & \\
\hline
\end{tabular}

The following prep procedures were performed:

TRACE

FOD $\quad 08 / 23 / 95 \quad 1730 \quad 71530 \quad 2$ 


\section{GENERAL ENGINEERING LABORATORIES}

Meeting today's needs with a vision for tomorrow.

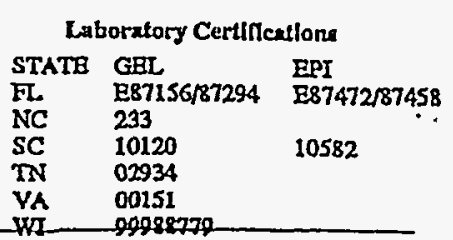

\section{CERTIFICATE OF ANALYSIS}

Client: Westinghouse Savannah River Co.

EPD-Building 773-58A

Aiken, South Carolins 29808-0001

Contact: Mr. Bob Craig

Project Description:

Analytical Services for SRS Environnental Characterization

Report Date: September 01, 1995

Page 1 of 2

$\begin{array}{ll}\text { Samplo ID } & : \text { COMP-1 } \\ \text { LabID } & : 9508156-08 \\ \text { Matrix } & : \text { Soil } \\ \text { Date Collected } & : 07 / 20 / 95 \\ \text { Date Received } & : 08 / 02 / 95 \\ \text { Priority } & : \text { Routine } \\ \text { Collector } & : \text { Cliont }\end{array}$

\begin{tabular}{|c|c|c|c|c|c|c|c|c|c|c|}
\hline Parameter & Qualifter & Result & & DL & RL Units & $\mathrm{DF}$ & Analyst Date & Time & Batch & $\mathbf{M}$ \\
\hline \multicolumn{11}{|l|}{ Metals Analysls } \\
\hline Silver & $\mathbf{U}$ & 53.9 & & 177 & 177 UGKG & 1.0 & NRM 08/24/95 & 1915 & 71530 & 1 \\
\hline Aluminum & & 58400 & & 847 & 1420 UGKG & 1.0 & & & & \\
\hline Arsenic & & 11100 & & 132 & 356 UGKG & 1.0 & & & & \\
\hline Barium & & 1130 & & 4.72 & 214 UGKG & 1.0 & & & & \\
\hline Beryllium & $\mathbf{J}$ & 1.78 & & 0.812 & 214 UGKG & 1.0 & & & & \\
\hline Calcium & & .3580000 & & 1420 & 1420 UGKG & 1.0 & & & & \\
\hline Cadmium & & 5540 & & 6.91 & 142 UGKG & 1.0 & & & & \\
\hline Cobalt & & 7860 & & 12.5 & 285 UGKG & 1.0 & & & & \\
\hline Clromiunn & & 523 & & 42.4 & · 285 UGKG & 1.0 & & & & \\
\hline Copper & & 15400 & · & 38.4 & 285 UGKG & 1.0 & & & & \\
\hline Iron & & 342000 & . & 719 & 1280 UGKG & 1.0 & & & & \\
\hline Potassium & & 6340000 & & 458 & 35600 UGKG & 1.0 & & & & \\
\hline Magnesium & & 976000 & & 167 & 1420 UGKG & 1.0 & & & & \\
\hline Manganese & & 22200 & & 6.85 & 142 UGKG & 1.0 & & & & \\
\hline Sodium & & 6930000 & & 1110 & 7120 UGKG & 1.0 & & & & \\
\hline Nickel & & 859 & & 57.5 & 712 UGKG & 1.0 & & & & \\
\hline Lead & & 1070 & & 80.5 & 356 UGKG & 1.0 & & & & \\
\hline Antimony & & 3000 & & 68.2 & 356 UGKG & 1.0 & & & & \\
\hline Selenium & & 4270 & & 102 & 356 UGKG & 1.0 & & & & \\
\hline Thallium & $U$ & -1300 & & 147 & 356 UGKG & 1.0 & & & & \\
\hline Uranium by ICP & $\mathrm{U}$ & -114 & & 429 & 1420 UGKG & 1.0 & & & & \\
\hline Vanadium & $\mathrm{J}$ & 299 & & 16.7 & 712 UGKG & 1.0 & & & & \\
\hline Zinc & & 114000 & & 192 & 356 UGKG & 1.0 & & & & \\
\hline
\end{tabular}

The following prep procedures were performed:

TRACE 


\section{GENERAL ENGINEERING LABORATORIES}

Meeting today's needs with a vision for tomorrow.

\section{CERTIFICATE OF ANALYSIS}

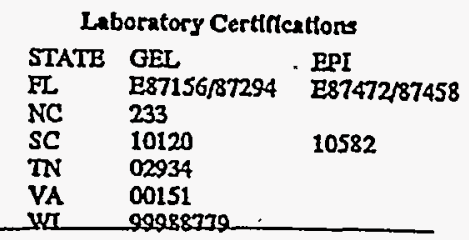

$\begin{aligned} \text { Client: } & \begin{array}{l}\text { Westinghouse Savannah River Co. } \\ \text { EPD-Building 773-58A }\end{array} \\ & \begin{aligned} & \text { Aiken, South Carolina 29808-0001 } \\ & \text { Contact: } \text { Mr. Bob Craig }\end{aligned} \\ \text { Project Description: } & \text { Analytical Services for SRS Environmental Characterization }\end{aligned}$

cc: WSRC00193

Report Date: September 01, 1995

Page 1 of 2

$\begin{array}{ll}\text { Sample ID } & : \text { COMP-2 } \\ \text { Lab ID } & : 9508156-09 \\ \text { Marrix } & : \text { Soil } \\ \text { Date Collected } & : 07 / 20 / 95 \\ \text { Date Received } & : 08 / 02 / 95 \\ \text { Priority } & : \text { Rontine } \\ \text { Collector } & : \text { Client }\end{array}$

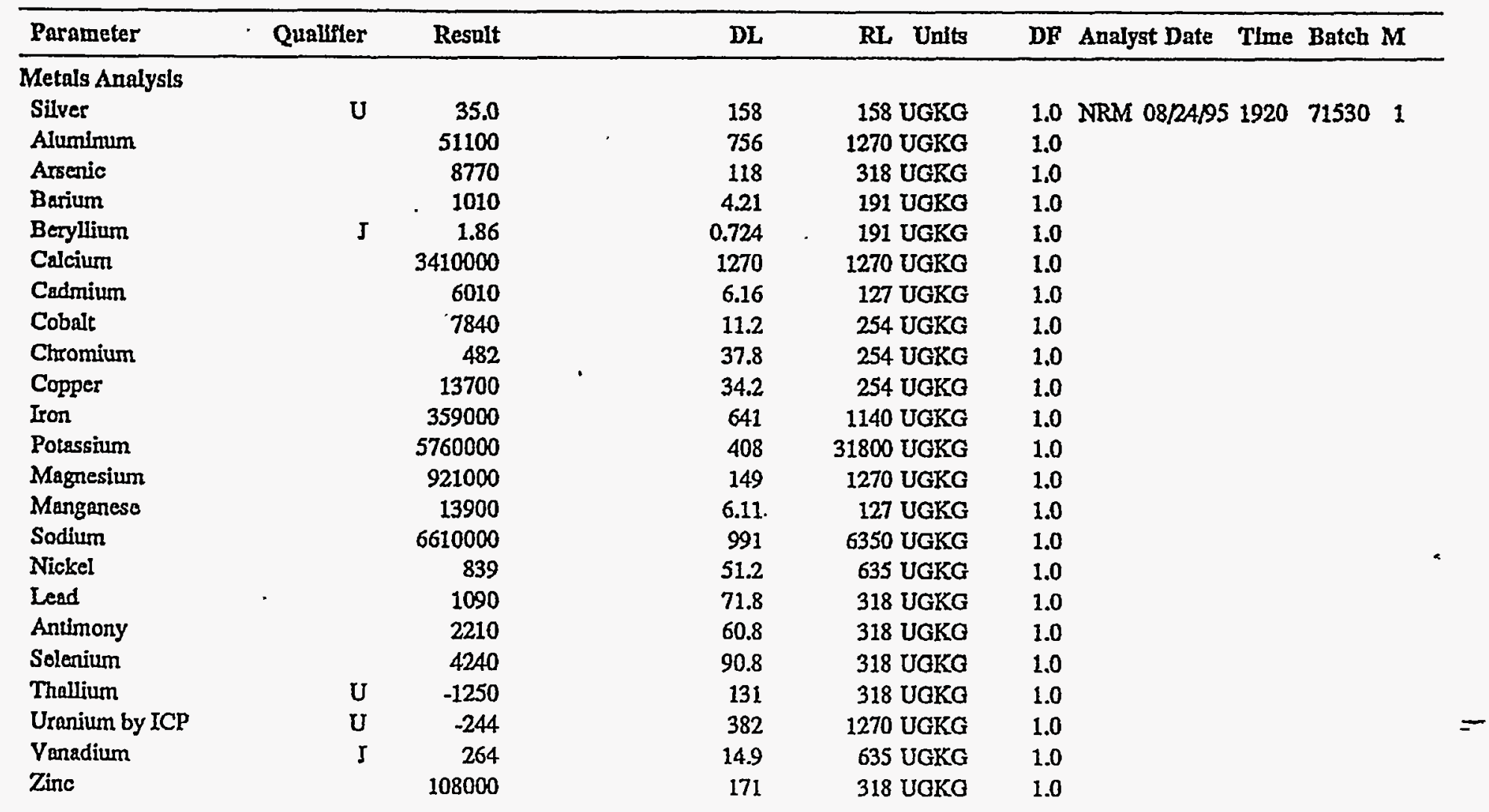

The following prep procedures were performed:

TRACE

FGD $\quad 08 / 23 / 95 \quad 1730 \quad 71530 \quad 2$

P O Box 30712 • Charleston, SC 29417 • (803) 556-817] • Tax (803) 766-1178

Ported an recicled paper 


\section{GENERAL ENGINEERING LABORATORIES}

Meeting today's needs with a vision for tomorrow.

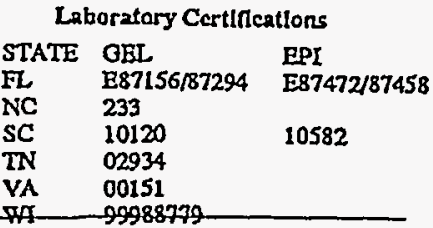

CERTIFICATE OF ANALYSIS

Client: Westinghouse Savannah River Co.

EPD-Building 773-58A

Aiken, South Carolina 29808-0001

Contact: Mr. Bob Craig

Project Description: Analytical Services for SRS Environmental Characterization

cc: WSRC00193

Report Date: September 01, 1995

Page 1 of 2

$\begin{array}{ll}\text { Sample ID } & : \text { COMP-3 } \\ \text { Lab ID } & : 9508156-10 \\ \text { Matrix } & : \text { Soil } \\ \text { Date Collected } & : 07 / 20 / 95 \\ \text { Date Received } & : 08 / 0295 \\ \text { Priority } & : \text { Routine } \\ \text { Collector } & : \text { Client }\end{array}$

\begin{tabular}{|c|c|c|c|c|c|c|c|c|c|}
\hline Parameter & Quallfier & Result & DL & RL Units & DF & Analyst Date & Time & Batch & $\mathbf{M}$ \\
\hline \multicolumn{10}{|l|}{ Metals Analysis } \\
\hline Silver & $\mathbf{U}$ & 46.7 & 185 & 185 UGKG & 1.0 & NRM 08/24/95 & 51924 & 71530 & 1 \\
\hline Aluminum & & 52000 & 885 & 1490 UGKG & 1.0 & & & & \\
\hline Arsenic & & 11500 & 138 & 372 UGKG & 1.0 & & & & \\
\hline Barium & & 917 & 4.93 & 223 UGKG & 1.0 & & & & \\
\hline Beryllium & 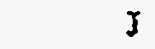 & 1.90 & 0.848 & 223 UGKG & 1.0 & & & & \\
\hline Calcium & & 3870000 & 1490 & 1490 UGKG & 1.0 & & & & \\
\hline Cadmium & & 6280 & 7.22 & 149 UGKG & 1.0 & & & & \\
\hline Cobalt & & 8280 & 13.1 & 298 UGKG & 1.0 & & & & \\
\hline Chromium & & 598 & 44.3 & 298 UGKG & 1.0 & & & & \\
\hline Copper & & 14500 & 40.1 & 298 UGKG & 1.0 & & & & \\
\hline Tron & & 398000 & 751 & 1340 UGKG & 1.0 & & & & \\
\hline Potassium & & 6270000 & 478 & 37200 UGKG & 1.0 & & & & \\
\hline Magnesium & & 965000 & 175 & 1490 UGKG & 1.0 & & & & \\
\hline Manganese & & 13900 & 7.16 & 149 UGKG & 1.0 & & . & & \\
\hline Sodium & & 6830000 & 1160 & 7440 UGKG & 1.0 & & & & \\
\hline Nickel & & 861 & 60.0 & 744 UGKG & 1.0 & & & & \\
\hline Lead & & 1110 & 84.1 & 372 UGKG & 1.0 & & & & \\
\hline Antimony & & 2650 & 71.3 & 372 UGKG & 1.0 & & & & \\
\hline Selenium & & 4300 & 106 & 372 UGKG & 1.0 & & & & \\
\hline Thallium & $U$ & -1380 & 154 & 372 UGKO & 1.0 & & & & \\
\hline Uranium by ICP & $\mathbf{U}$ & -778 & 448 & 1490 UGKG & 1.0 & & & & \\
\hline Vanadium & $\mathbf{J}$ & 261 & 17.4 & 744 UGKG & 1.0 & & & & \\
\hline Zinc & & 116000 & 201 & 372 UGKG & 1.0 & & & & \\
\hline
\end{tabular}

The following prep procedures were performed: 


\section{GENERAL ENGINEERING LABORATORUES}

Meeting today's needs with a vision for tomorrow.

CERTIFICATE OF ANALYSIS

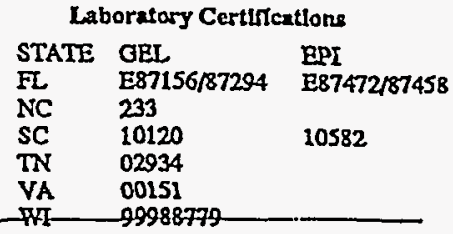

Client: Westinghouse Savannah River Co.

EPD-Building 773-58A

Aiken, South Carolina 29808-0001

Contact:

Mr. Bob Craig

Project Description:

Analytical Services for SRS Environmental Characterization

cc; WSRC00193

Report Date: September 01, 1995

Page 1 of 2

$\begin{array}{ll}\text { Sample ID } & : \text { ART-1 } \\ \text { Lab ID } & : 9508156-05 \\ \text { Matrix } & : \text { Soil } \\ \text { Date Collected } & : 07 / 20 / 95 \\ \text { Date Received } & : 08 / 02 / 95 \\ \text { Priority } & : \text { Routine } \\ \text { Colloctor } & : \text { Client }\end{array}$

\begin{tabular}{|c|c|c|c|c|c|c|c|c|c|}
\hline Parameter & Quallfler & Result & $\mathrm{DL}$ & RL Units & DF & Analyst Date & Time & Batch & $\mathbf{M}$ \\
\hline \multicolumn{10}{|l|}{ Metals Analysis } \\
\hline Silver & $\mathbf{U}$ & 94.2 & 202 & 202 UGKG & 1.0 & NRM $08 / 24 / 95$ & 1901 & 71530 & 1 \\
\hline Aluminum & & 35800 & 966 & 1620 UGKG & 1.0 & & & & \\
\hline Arsenic & & 8530 & 151 & 406 UGKG & 1.0 & & & & \\
\hline Barium & & 922 & 5.38 & 244 UGKG & 1.0 & & & & \\
\hline Beryllium & $\mathbf{U}$ & -0.685 & 0.926 & 244 UGKG & 1.0 & & & & \\
\hline Calcium & & 3650000 & 1620 & 1620 UGKC & 1.0 & & & & \\
\hline Cadmium & & 5730 & 7.88 & 162 UGKG & 1.0 & & & & \\
\hline Cobalt & & 10300 & 14.3 & 325 UGKG & 1.0 & & & & \\
\hline Chromium & & 449 & 48.4 & 325 UGKG & 1.0 & & & & \\
\hline Copper & & 10500 & 43.8 & 325 UGKG & 1.0 & & & & \\
\hline Iron & & 414000 & 820 & 1460 UGKG & 1.0 & & & & \\
\hline Potassium & & 5710000 & 522 & 40600 UGKG & 1.0 & & & & \\
\hline Magnesium & & 660000 & 191 & 1620 UGKG & 1.0 & & & & \\
\hline Manganese & & 6760 & 7.81 & 162 UGKG & 1.0 & & & & \\
\hline Sodium & & 5110000 & 1270 & 8120 UGKG & 1.0 & & & & 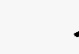 \\
\hline Nickel & J & 697 & 65.5 & 812 UGKG & 1.0 & & & & \\
\hline Lead & & 1100 & 91.8 & 406 UGKG & 1.0 & & & & . \\
\hline Antimony & & 2160 & 77.8 & 406 UGKO & 1.0 & & & & \\
\hline Seleniun & & 4850 & 116 & 406 UGKG & 1.0 & & & & \\
\hline Thallium & $\mathbf{U}$ & -1020 & 168 & 406 UGKG & 1.0 & & & & \\
\hline Uranium by ICP & U & -658 & 489 & 1620 UGKG & 1.0 & & & & \\
\hline Vanadium & $\mathrm{J}$ & 324 & 19.0 & 812 UGKG & 1.0 & & & & \\
\hline Zinc & & 112000 & 219 & 406 UGKG & 1.0 & & & & \\
\hline
\end{tabular}

The following prep procedures were performed:

TRACE

FGD $08 / 23 / 951730 \quad 71530 \quad 2$ 


\section{GENERAL ENGINEERING LABORATORIES}

Meeting today's needs with a vision for tomorrow.

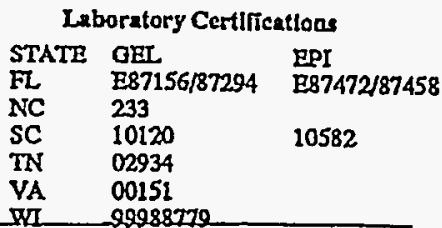

CERTIFICATE OF ANALYSIS

Client: Westinghouse Savannah River Co.

EPD-Building 773-58A

Aiken, South Carolina 29808-0001

Contact:

Mr. Bob Craig

Project Description:

Analytical Services for SRS Environmental Characterization

cc: WSRC00193

Report Date: September 01, 1995

Page 1 of 2

Sample ID

LabID

Matrix

Date Collected

Date Received

Priority

Collector
: ART-2
:9508156-06
: Soil
:07/20/95
:08/02/95
: Routine
: Client

\begin{tabular}{|c|c|c|c|c|c|c|c|c|c|}
\hline Parameter & Quallfier & Result & DL & RL Units & DF & Analyst Date & Time & Batch & $M$ \\
\hline \multicolumn{10}{|l|}{ Metals Analysls } \\
\hline Silver & U & 65.0 & 189 & 189 UGKO & 1.0 & NRM 08/24/95 & 1906 & 71530 & 1 \\
\hline Aluminum & & 79700 & 904 & 1520 UGKG & 1.0 & & & & \\
\hline Arsenic & & 36000 & 141 & 380 UGKG & 1.0 & 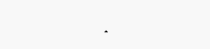 & & & \\
\hline Barium & & 1160 & 5.04 & 228 UGKG & 1.0 & & & & \\
\hline Beryllium & J & 5.07 & 0.866 & 228 UGKG & 1.0 & & & & \\
\hline Calcium & & 3570000 & 1520 & 1520 UGKG & 1.0 & & & & \\
\hline Cadmium & & 6420 & 7.37 & 152 UGKO & 1.0 & & & & \\
\hline Cobalt & & 11100 & 13.4 & 304 UGKG & 1.0 & & & & \\
\hline Chromium & & 1070 & 45.3 & 304 UGKG & 1.0 & & & & \\
\hline Copper & & 13800 & 41.0 & 304 UGKG & 1.0 & & & & \\
\hline Iron & & 510000 & 768 & 1370 UGKG & 1.0 & & & & \\
\hline Potassium & & 5950000 & 489 & 38000 UGKG & 1.0 & & & & \\
\hline Magnesium & & 678000 & 179 & 1520 UGKO & 1.0 & & & & \\
\hline Manganese & & 8470 & 7.31 & 152 UGKG & 1.0 & & & & \\
\hline Sodium & & 5450000 & 1190 & 7600 UGKG & 1.0 & & & & a \\
\hline Nickel & & 873 & 61.3 & 760 UGKG & 1.0 & & & & \\
\hline Lesd & & 1190 & 85.9 & 380 UGKG & 1.0 & & & & \\
\hline Antimony & & 2670 & 72.8 & 380 UGKG & 1.0 & & & & \\
\hline Selenium & & 4950 & $109^{\circ}$ & 380 UGKG & 1.0 & & & & \\
\hline Thallium & $U$ & -1120 & 157 & 380 UGKO & 1.0 & & & & \\
\hline Uranium by ICP & $\mathbf{U}$ & -121 & 458 & 1520 UGKG & 1.0 & & & & \\
\hline Vanadium & $\mathrm{J}$ & 613 & 17.8 & 760 UGKG & 1.0 & & & & \\
\hline Zinc & & 113000 & 205 & 380 UGKG & 1.0 & & & & \\
\hline
\end{tabular}

The following prep procedures were performed: 


\section{GENERAL ENGINEERING LABORATORIES}

Meeting today's needs with a vision for tomorrow.

\begin{tabular}{lll}
\multicolumn{3}{c}{ Laboratory Certlficationa } \\
STATE & GEL & EPI \\
FL & E87156/87294 & E87472/87458 \\
NC & 233 & \\
SC & 10120 & 10582 \\
TN & 02934 & \\
YA & 00151 & \\
WI & 99988720 & \\
\hline
\end{tabular}

\section{CERTIFICATE OF ANALYSIS}

Client: Westinghouse Savannah River Co. .

EPD-Bullding 773-58A

Aiken, South Carolina 29808-0001

Contact: Mr. Bob Craig

Project Description: Analytical Services for SRS Environmental Characterization

co: WSRC00193

Report Date: September 01, 1995

Page 1 of 2

\begin{tabular}{ll}
\hline Sample ID & $:$ ART-3 \\
Lab ID & $: 9508156-07$ \\
Marix & $:$ Soil \\
Date Collected & $: 07 / 20 / 95$ \\
Date Received & $: 08 / 02 / 95$ \\
Priority & $:$ Routine \\
Collector & $:$ Client
\end{tabular}

\begin{tabular}{|c|c|c|c|c|c|c|c|c|c|}
\hline Parameter & Qualfiter & Result & DL & RL Units & $\mathrm{DF}$ & Analyst Date & Time & Batch I & $\mathbf{M}$ \\
\hline \multicolumn{10}{|l|}{ Metals Analysis } \\
\hline Silver & $\cdot \mathbf{U}$ & $34 A$ & 213 & 213 UGKG & 1.0 & NRM 08/24/95 & 1911 & 71530 & 1 \\
\hline Aluminum & & 82800 & 1020 & 1710 UOKG & 1.0 & & & & \\
\hline Arsenic & & 7050 & 159 & 428 UGKG & 1.0 & & & & \\
\hline Barium & & 1240 & 5.68 & 257 UGKG & 1.0 & & & & \\
\hline Beryllium & $\mathbf{J}$ & 1.77 & 0.976 & 257 UGKG & 1.0 & & & & \\
\hline Calcium & & 3670000 & 1710 & 1710 UGKG & 1.0 & & & & \\
\hline Cadmium & & 5470 & 8.30 & 171 UGKG & 1.0 & & & & \\
\hline Cobalt & & 8400 & 15.1 & 342 UaKO & 1.0 & & & & \\
\hline Chromium & & 599 & 51.0 & 342 UGKG & 1.0 & & & & \\
\hline Copper & & 10400 & 46.1 & 342 UGKG & 1.0 & & & & \\
\hline Iron & & 382000 & 865 & 1540 UGKG & 1.0 & & & & \\
\hline Potassium & & 5860000 & 550 & 42800 UGKG & 1.0 & & & & \\
\hline Magnesium & & 670000 & 201 & 1710 UGKG & 1.0 & & & & \\
\hline Manganese & & 6850 & 8.23 & 171 UaKG & 1.0 & & & & \\
\hline Sodium & & 4870000 & 1340 & 8560 UGKG & 1.0 & & & & \\
\hline Nickel & $\mathrm{J}$ & 820 & 69.1 & 856 UGKG & 1.0 & & & & “ \\
\hline Lead & & 1300 & 96.7 & 428 UGKG & 1.0 & & & & \\
\hline Antimony & & 2970 & 82.0 & 428 UGKG & 1.0 & & & & \\
\hline Selenium & & 3990 & 122 & 428 UGKG & 1.0 & & & & \\
\hline Thallium & $U$ & -1200 & 177 & 428 UGKG & 1.0 & & & & \\
\hline Uranium by ICP & $\mathrm{U}$ & -204 & 515 & 1710 UGKG & 1.0 & & & & \\
\hline Vanadium & Y & 422 & 20.0 & 856 UGKG & 1.0 & & & & \\
\hline Zinc & & 107000 & 231 & 428 UGKG & 1.0 & & & & \\
\hline
\end{tabular}

The following prep procedures were performed:

TRACE 


\section{GENERAL ENGINEERING LABORATORIES}

Meeting today's needs with a vision for tomorrow.

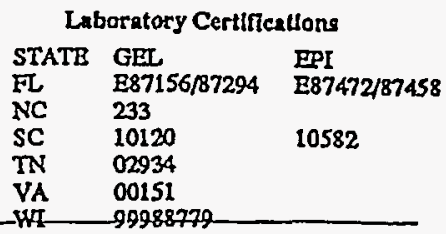

CERTIFICATE OF ANALYSIS

Client: Westinghouse Savannah River Co.

EPD-Building 773-58A:

Aiken, South Carolina 29808-0001

Contact: Mr. Bob Craig

Project Description: Analytical Services for SRS Environmental Characterization

cc: WSRC00193

Report Date: September 01, 1995

Page 1 of 2

$\begin{array}{ll}\text { Sample ID } & \text { : DCPRB-1 } \\ \text { Lab ID } & : 9508156-11 \\ \text { Matrix } & : \text { Soil } \\ \text { Date Collected } & : 07 / 2095 \\ \text { Date Received } & : 08 / 02 / 95 \\ \text { Priority } & : \text { Routine } \\ \text { Collector } & : \text { Client }\end{array}$

\begin{tabular}{|c|c|c|c|c|c|c|c|c|c|c|}
\hline Parameter & Quallfier & Result & & $\mathbf{D L}$ & RL Unlts & DF & Analyst Date & Time & Batch & $M$ \\
\hline \multicolumn{11}{|l|}{ Metals Analysis } \\
\hline Silver & $\mathbf{U}$ & 40.3 & & 182 & 182 UGKG & 1.0 & NRM 08/24/95 & 1943 & 71530 & 1 \\
\hline Aluminum & & 82200 & & 868 & 1460 UGKG & 1.0 & & & & \\
\hline Arsenic & & 6970 & & 136 & 365 UGKG & 1.0 & & & & \\
\hline Barium & & 521 & & 4.83 & 219 UGKG & 1.0 & & & & \\
\hline Beryllium & $J$ & 7.37 & & 0.831 & 219 UGKG & 1.0 & & & & \\
\hline Calcium & & 3620000 & & 1460 & 1460 UGKG & 1.0 & & & & \\
\hline Cadmium & & 4940 & & 7.07 & 146 UOKG & 1.0 & & & & \\
\hline Cobalt & & 5840 & & 12.8 & 292 UGKG & 1.0 & & & & \\
\hline Chromium & & 709 & & 43.4 & 292 UGKG & 1.0 & & & & \\
\hline Copper & & 11900 & ' & 39.3 & 292 UGKG & 1.0 & & & & \\
\hline Iron & & 504000 & & 736 & 1310 UGKG & 1.0 & & & & \\
\hline Potassium & & 6110000 & & 469 & 36500 UGKG & 1.0 & & & & \\
\hline Magnesium & & 670000 & & 171 & 1460 UGKG & 1.0 & & & & \\
\hline Mangarese & & 8950 & & 7.01 & 146 UGKO & 1.0 & & & & \\
\hline Sodium & & 6290000 & & 1140 & 7290 UGKG & 1.0 & & & & . \\
\hline Nickel & & 2830 & & 58.8 & 729 UAKG & 1.0 & & & & \\
\hline Lead & & 1080 & & 82.4 & 365 UGKG & 1.0 & & & & \\
\hline Antimony & & 1690 & & 69.8 & 365 UOKG & 1.0 & & & & \\
\hline Selenium & & 4310 & & 104 & 365 UGKG & 1.0 & & & & \\
\hline Thallium & $\mathrm{U}$ & -989 & & 151 & 365 UGKG & 1.0 & & & & \\
\hline Uranium by ICP & $\mathrm{U}$ & -409 & & 439 & 1460 UGKG & 1.0 & & & & \\
\hline Vanadium & $\mathbf{J}$ & 283 & & 17.1 & 729 UGKG & 1.0 & & & & \\
\hline Zinc & & 99700 & & 197 & 365 UGKG & 1.0 & & & & \\
\hline
\end{tabular}

The following prep procedures were performed: TRACE 


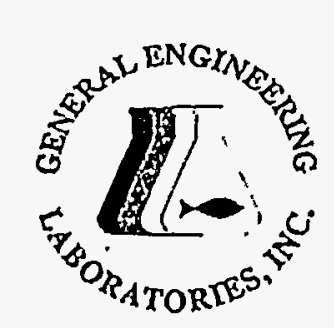

\section{GENERAL ENGINEERING LABORATORIES}

Meeting today's needs with a vision for tomorrow.

CERTIFICATE OF ANALYSIS

Client: Westinghouse Savannah River Co.

EPD-Building 773-58A

Aiken, South Carolina 29808-0001

Contact: Mr. Bob Craig

Project Description: Analytical Services for SRS Environmental Characterization

c: WSRC00193

Report Date: September 01, 1995

Page 1 of 2

$\begin{array}{ll}\text { Sample ID } & : \text { DCPRB-2 } \\ \text { Lab ID } & : 9508156-12 \\ \text { Matrix } & : \text { Soil } \\ \text { Date Collected } & : 07 / 20 / 95 \\ \text { Date Recelved } & : 08 / 0295 \\ \text { Priority } & : \text { Routine } \\ \text { Collector } & : \text { Client }\end{array}$

\begin{tabular}{|c|c|c|c|c|c|c|c|c|c|}
\hline Parameter & Quallfler & Result & DL & RL Units & DF & Analyst Date & Tlme & Batch $N$ & $M$ \\
\hline \multicolumn{10}{|l|}{ Metals Analyals } \\
\hline Silver & $\mathbf{U}$ & 25.9 & 181 & 181 UGKG & 1.0 & NRM 08/2A/95 & 1948 & 71530 & 1 \\
\hline Alumimum & & 188000 & 865 & 1450 UGKG & 1.0 & & & & \\
\hline Arsenic & & 9760 & 135 & 364 UGKG & 1.0 & & & & \\
\hline Barium & & 1180 & 4.82 & 218 UGKG & 1.0 & & & & \\
\hline Beryllium & $\mathbf{J}$ & 13.2 & 0.829 & 218 UGKG & 1.0 & & & & \\
\hline Calcium & & 3700000 & 1450 & 1450 UGKG & 1.0 & & & & \\
\hline Cedmium & & 5840 & 7.05 & 145 UGKG & 1.0 & & & & \\
\hline Cobalt & & 6200 & 12.8 & 291 UaKG & 1.0 & & & & \\
\hline Chromium & & 1320 & 43.3 & 291 UGKO & 1.0 & & & & \\
\hline Copper & & 12300 & 39.2 & 291 UGKG & 1.0 & & & & \\
\hline Iron & & 827000 & 734. & 1310 UGKO & 1.0 & & & & \\
\hline Potassium & & 6190000 & 467 & 36400 UGKG & 1.0 & & & & \\
\hline Magnesium & & 702000 & 171 & 1450 UGKG & 1.0 & & & & \\
\hline Manganese & & 11200 & 6.99 & 145 UGKG & 1.0 & & & & \\
\hline Sodium & & 6000000 & 1130 & 7270 UGKG & 1.0 & & & & \\
\hline Nickel & & 2130 & 58.7 & 727 UGKG & 1.0 & & & & \\
\hline Lead & & 1330 & 82.2 & 364 UGKG & 1.0 & & & & \\
\hline Antimony & & 1960 & 69.6 & 364 UGKG & 1.0 & & & & \\
\hline Selenium & & 4130 & 104 & 364 UGKG & 1.0 & & & & \\
\hline Thallium & $\mathbf{U}$ & -940 & 150 & 364 UGKG & 1.0 & & & & \\
\hline Uranium by ICP & $\mathbf{U}$ & -567 & 438 & 1450 UOKG & 1.0 & & & & \\
\hline Vanadium & $\mathbf{J}$ & 575 & 17.0 & 727 UGKG & 1.0 & & & & \\
\hline Zinc & & 105000 & 196 & 364 UGKG & 1.0 & & & & \\
\hline
\end{tabular}

The following prep procedures were performed:

TRACE 


\title{
GENERAL ENGINEERING LABORATORIES
}

\author{
Meeting today's needs with a vision for tomorrow.
}

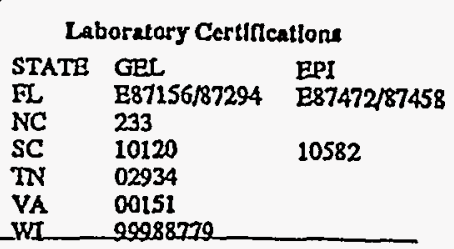

CERTIFICATE OF ANALYSIS

Client: Westinghouso Savannah River Co.

EPD-Building 773-58A

Aiken, South Carolina 29808-0001

Contact: Mr. Bob Craig

Project Description:

Analytical Services for SRS Environmental Characterization

cc: WSRC00193

Report Date: September 01, 1995

Page 1 of 2

$\begin{array}{ll}\text { Sample ID } & : \text { DCPRB-3 } \\ \text { Lab ID } & : 9508156-13 \\ \text { Matrix } & : \text { Soil } \\ \text { Date Collected } & : 07 / 20 / 95 \\ \text { Date Received } & : 08 / 02 / 95 \\ \text { Priority } & : \text { Routine } \\ \text { Collactor } & \text { : Client }\end{array}$

\begin{tabular}{|c|c|c|c|c|c|c|c|c|c|}
\hline Parameter & Quallfter & Result & DL & RL Unlts & $\mathrm{DF}$ & Analyst Date & Time & Batch & $\mathbf{M}$ \\
\hline \multicolumn{10}{|l|}{ Metals Analysls } \\
\hline Silver & $\mathrm{U}$ & 28.8 & 224 & 224 UGKG & 1.0 & NRM 08/24/95 & 1953 & 71530 & 1 \\
\hline Alnminum & & 51600 & 1070 & 1800 UaKG & 1.0 & & & & \\
\hline Arsenic & & 6000 & 167 & 450 UGKG & 1.0 & & & & \\
\hline Barium & & 350 & 5.96 & 270 UGKG & 1.0 & & & & \\
\hline Beryllium & J & 3.45 & 1.02 & 270 UGKG & 1.0 & & & & \\
\hline Calcium & & 3370000 & 1800 & 1800 UGKG & 1.0 & & & & \\
\hline Cadmium & & 4520 & 8.72 & 180 UGKG & 1.0 & & & & \\
\hline Cobalt & & 5420 & 15.8 & 360 UGKG & 1.0 & & & & \\
\hline Chromium & & 656 & 53.6 & 360 UGKG & 1.0 & & & & \\
\hline Copper & & 10200 & 48.5 & 360 UGKG & 1.0 & & & & \\
\hline Iron & & 384000 & 908 & 1620 UGKG & 1.0 & & & & \\
\hline Potassium & & 7100000 & 578 & 45000 UGKG & 1.0 & & & & \\
\hline Magnesium & & 731000 & 211 & 1800 UGKG & 1.0 & & & & \\
\hline Manganese & & 10000 & 8.65 & 180 UGKG & 1.0 & & & & \\
\hline Sodium & & 7340000 & 1400 & 8990 UGKG & 1.0 & & & & \\
\hline Nickel & & 1700 & 72.5 & 899 UGKG & 1.0 & & & & \\
\hline Lead & & 955 & 102 & 450 UGKG & 1.0 & & & & \\
\hline Antimony & & 2320 & 86.1 & 450 UGKG & 1.0 & & & & \\
\hline Selenium & & 3890 & 129. & 450 UGKG & 1.0 & & & & \\
\hline Thallium & $U$ & -970 & $186^{\circ}$ & 450 UGKG & 1.0 & & & & \\
\hline Uranium by ICP & $\mathrm{U}$ & -1130 & 541 & 1800 UGKO & 1.0 & & & & \\
\hline Vanadium & I & 200 & 21.0 & 899 UGKG & 1.0 & & & & \\
\hline Zinc & & 103000 & 243 & 450 UaKO & 1.0 & & & & \\
\hline
\end{tabular}

The following prep procedures were performed:

TRACE 


\section{GENERAL ENGINEERING LABORATORIES}

Meeting today's needs with a vision for tomorrow.

CERTIFICATE OF ANALYSIS

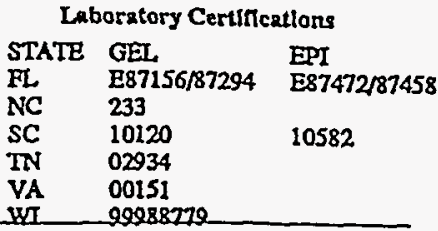

Client: Westinghouse Savannah River Co.

EPD-Building 773-58A

Contact:

Aiken, South Carolina 29808-0001

Project Doscription:

œ: WSRC00193

Report Date: September 01, 1995

Page 1 of 2

$\begin{array}{ll}\text { Sample ID } & : \text { PCPRB-1 } \\ \text { Lab ID } & : 9508156-14 \\ \text { Matrix } & : \text { Soil } \\ \text { Date Collected } & : 07 / 20 / 95 \\ \text { Date Received } & : 08 / 02 / 95 \\ \text { Priority } & \text { : Routine } \\ \text { Collector } & : \text { Client }\end{array}$

\begin{tabular}{|c|c|c|c|c|c|c|c|c|c|c|}
\hline Parameter & Quallfier & Result & & DL & RL Units & $\mathrm{DF}$ & Analyst Date & Time & Batch & $M$ \\
\hline \multicolumn{11}{|l|}{ Metals Analysis } \\
\hline Silver & $\boldsymbol{U}$ & 57.1 & . & 244 & 244 UGKG & 1.0 & NRM 08/24/95 & 1957 & 71530 & 1 \\
\hline Aluminum & & 123000 & & 1170 & 1960 UGKG & 1.0 & & & & \\
\hline Arsenic & & 6480 & & 182 & 490 UGKG & 1.0 & & & & \\
\hline Barium & & 656 & & 6.50 & 294 UGKG & 1.0 & & & & \\
\hline Beryllium & $\mathrm{J}$ & 7.03 & & 1.12 & 294 UGKO & 1.0 & & & & \\
\hline Calcium & & 3470000 & & 1960 & 1960 UGKG & 1.0 & & & & \\
\hline Cadmium & & 6140 & & 9.51 & 196 UGKG & 1.0 & & & & \\
\hline Cobait & & 7930 & & 17.2 & 392 UaKG & 1.0 & & & & \\
\hline Chromium & & 558 & & 58.4 & 392 UGKG & 1.0 & & & & \\
\hline Copper & & 16700 & , & 52.8 & 392 UGKG & 1.0 & & & & \\
\hline Iron & & 404000 & & 990 & 1760 UGKG & 1.0 & & & & \\
\hline Potassiurn & & 5000000 & & 630 & 49000 UGKG & 1.0 & & & & \\
\hline Magnesium & & 670000 & & 230 & 1960 UaKG & 1.0 & & & & \\
\hline Manganese & & 9790 & & 9.43 & 196 UGKG & 1.0 & & & & \\
\hline Sodium & & 4650000 & & 1530 & 9800 UGKG & 1.0 & & & & \\
\hline Nickel & & 2170 & & 79.1 & 980 UGKG & 1.0 & & & & \\
\hline Lead & & 1700 & & 111 & 490 UGKO & 1.0 & & & & \\
\hline Antimony & & 2110 & & 93.9 & 490 UGKG & 1.0 & & & & \\
\hline Selenium & & 4760 & & 140 & 490 UGKG & 1.0 & & & & \\
\hline Thallium & $\mathbf{U}$ & -1120 & & 203 & 490 UGKG & 1.0 & & & & \\
\hline Uranium by ICP & U & -541 & & 590 & 1960 UGKG & 1.0 & & & & \\
\hline Vanadium & $J$ & 267 & & 22.9 & 980 UGKG & 1.0 & & & & \\
\hline Zinc & & 116000 & & 265 & 490 UGKG & 1.0 & & & & \\
\hline
\end{tabular}

The following prep procedures were performed:

TRACE 


\section{GENERAL ENGINEERING LABORATORIES}

Mecting today's needs with a vision for tomorrow.

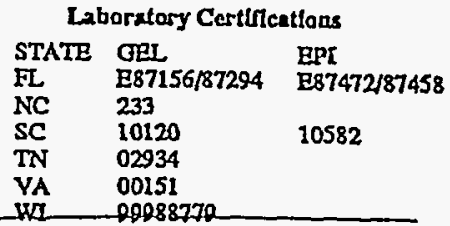

CERTIFICATE OF ANALYSIS

Client: Westinghouse Savannah River Co.

EPD-Building 773-58A

Aiken, South Carolina 29808-0001

Contact: Mr. Bob Craig

Project Description: Analytical Services for SRS Environmental Characterization

cc: WSRC00193

Report Date: September 01, 1995

Page 1 of 2

$\begin{array}{ll}\text { Sample ID } & : \text { PCBRB-2. } \\ \text { Lab ID } & : 9508156-15 \\ \text { Matrix } & : \text { Soil } \\ \text { Date Collected } & : 07 / 20 / 95 \\ \text { Date Received } & : 08 / 02 / 95 \\ \text { Priority } & : \text { Routine } \\ \text { Collector } & : \text { Client }\end{array}$

\begin{tabular}{|c|c|c|c|c|c|c|c|c|c|c|}
\hline Parameter & Quallfler & Result & & DL & RI Units & $\overline{D F}$ & Analyst Date & Time & Batch & $M$ \\
\hline \multicolumn{11}{|l|}{ Metals Analysis } \\
\hline Silver & $\mathbf{U}$ & 9.24 & & 240 & 240 UGKG & 1.0 & NRM 08/24/95 & 2002 & 71530 & 1 \\
\hline Alụminum & & 108000 & & 1150 & 1930 UGKG & 1.0 & & & & \\
\hline Arsenic & & 7940 & & 179 & 483 UGKG & 1.0 & & & & \\
\hline Barium & & 547 & & 6.40 & 290 UGKG & 1.0 & & & & \\
\hline Beryllium & $\mathbf{J}$ & 4.07 & & 1.10 & 290 UGKG & 1.0 & & & & \\
\hline Calcium & & 3290000 & & 1930 & 1930 UGKG & 1.0 & & & & \\
\hline Cadmium & & 6170 & & 9.36 & 193 UGKG & 1.0 & & & & \\
\hline Cobalt & & 7880 & & 17.0 & 386 UGKG & 1.0 & & & & \\
\hline Chromium & & 532 & & 57.5 & 386 UGKG & 1.0 & & & & \\
\hline Copper & & 15800 & $\cdot$ & 52.0 & 386 UGKG & 1.0 & & & & \\
\hline Iron & & 380000 & & .975 & 1740 UGKG & 1.0 & & & & \\
\hline Potassium & & 5340000 & & 620 & 48300 UGKG & 1.0 & & & & \\
\hline Magnesium & & 662000 & & 227 & 1930 UGKG & 1.0 & & & & \\
\hline Manganese & & 9960 & & 9.28 & 193 UGKG & 1.0 & & & & \\
\hline Sodium & & 5000000 & & 1510 & 9650 UaKG & 1.0 & & & & \\
\hline Nickel & & 1720 & & 77.9 & 965 UGKG & 1.0 & & & & \\
\hline Lead & & 1220 & & 109 & 483 UGKG & 1.0 & & & & \\
\hline Antimony & & 2330 & & $92: 4$ & $483 \mathrm{UGKG}$ & 1.0 & & & & " \\
\hline Selenium & & 4720 & & 138 & 483 UGKG & 1.0 & & & & \\
\hline Thallium & $U$ & -1160 & & 200 & 483 UGKG & 1.0 & & & & \\
\hline Uranium by ICP & $\mathbf{U}$ & -537 & & 581 & 1930 UGKG & 1.0 & & & & \\
\hline Vanadium & $\mathbf{J}$ & 269 & & 22.6 & 965 UGKG & 1.0 & & & & \\
\hline Zine & & 111000 & & 261 & 483 UGKG & 1.0 & & & & \\
\hline
\end{tabular}

he following prep procedures were performed:

RACE 


\section{GENERAL ENGINEERING LABORATORIES}

Meeting today's needs with a vision for tomorrow.

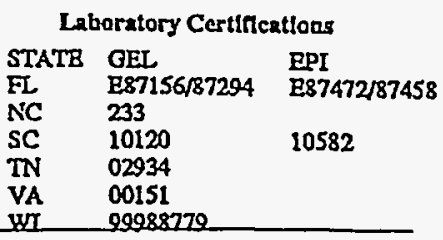

\section{CERTIFICATE OF ANALYSIS}

Client: Westinghouse Savannah River Co.

EPD-Building 773-58A

Aiken, South Carolina 29808-0001

Contect: Mr. Bob Craig

Project Description: $\quad$ Analytical Services for SRS Environmental Characterization

cc: WSRC00193

Report Date: September 01, 1995

Page 1 of 2

\begin{tabular}{lll}
\hline Samplo ID & : PCBRB-3 \\
LabID & $: 9508156-16$ \\
Matrix & $:$ Soil \\
Date Collected & $: 07 / 20 / 95$ \\
Date Received & $:$ :08/02/95 \\
Priority & : Routine \\
Collector & : Client
\end{tabular}

\begin{tabular}{|c|c|c|c|c|c|c|c|c|c|}
\hline Parameter & Qualffer & Result & DL & RL Units & $\mathrm{DF}$ & Analyst Date & Time & Batch & $M$ \\
\hline \multicolumn{10}{|l|}{ Metals Analysis } \\
\hline Silver & $\mathbf{U}$ & 11.1 & 236 & 236 UGKG & 1.0 & NRM 08/24/95 & 2007 & 71530 & 1 \\
\hline Aluminum & & 158000 & 1130 & 1890 UOKG & 1.0 & & & & \\
\hline Arsenic & & 8600 & 176 & 474 UGKG & 1.0 & & & & \\
\hline Barium & & 885 & 6.28 & 284 UGKG & 1.0 & & & & \\
\hline Beryllium & J & 8.80 & 1.08 & 284 UGKG & 1.0 & & & & \\
\hline Calcium & & 3660000 & 1890 & 1890 UGKG & 1.0 & & & & \\
\hline Cadmium & & 6040 & 9.19 & 189 UGKG & 1.0 & & & & \\
\hline Cobalt & & 6970 & 16.7 & 379 UGKG & 1.0 & & & & \\
\hline Chromium & & 646 & 56.4 & 379 UGKG & 1.0 & & & & \\
\hline Copper & & 17400 & 51.0 & 379 UGKG & 1.0 & & & & \\
\hline Iron & & 429000 & 956 & 1700 UGKG & 1.0 & & & & \\
\hline Potassium & & 5580000 & 609 & 47400 UGKG & 1.0 & & & & \\
\hline Magnesium & & 717000 & 223 & 1890 UGKG & 1.0 & & & & \\
\hline Manganese & & 11400 & 9.11 & 189 UGKG & 1.0 & & & & \\
\hline Sodium & & 5010000 & 1480 & 9470 UGKG & 1.0 & & & & \\
\hline Nickel & & 2330 & $76.4^{\circ}$ & 947 UOKG & 1.0 & & & & \\
\hline Lead & & 1140 & 107 & 474 UGKG & 1.0 & & & & \\
\hline Antimony & & 2220 & 90.7 & 474 UOKG & 1.0 & & & & \\
\hline Selenium & & 4750 & 135 & 474 UGKG & 1.0 & . & & & \\
\hline Thallium & U & -602 & 196 & 474 UGKG & 1.0 & & & & \\
\hline Uranium by ICP & $\mathrm{U}$ & -739 & 570 & 1890 UGKG & 1.0 & & & & \\
\hline Vanadium & $J$ & 314 & 22.2 & 947 UGKG & 1.0 & & & & \\
\hline Zinc & & 114000 & 256 & 474 UGKG & 1.0 & & & & \\
\hline
\end{tabular}

The following prep procedures were performed: TRACE 


\section{GENERAL ENGINEERING LABORATORIES}

Meeting today's needs with a vision for tomorrow.

Laboratory Ccrtfficatlons

$\begin{array}{lll}\text { STATE } & \text { GEL } & \text { EPI } \\ \text { FL } & \text { E87156/87294 } & \text { E87472/87458 } \\ \text { NC } & 233 & \\ \text { SC } & 10120 & 10582 \\ \text { TN } & 02934 & \\ \text { VA } & 00151 & \\ \text { WU } & 99988779 & \end{array}$

CERTIFICATE OF ANALYSIS

Client: Westinghouse Savannah River Co.

EPD-Building 773-58A

Aiken, South Carolina 29808-0001

Contact: Mr. Bob Craig

Projoct Descriptioni Anslytical Services for SRS Environmental Characterization

$\begin{array}{ll}\text { Sample ID } & : \text { STED-1 } \\ \text { Lab ID } & : 9508156-17 \\ \text { Matrix } & : \text { Soil } \\ \text { Date Collected } & : 07 / 20 / 95 \\ \text { Date Received } & : 08 / 02 / 95 \\ \text { Priority } & : \text { Routine } \\ \text { Collector } & : \text { Client }\end{array}$

\begin{tabular}{|c|c|c|c|c|c|c|c|c|c|}
\hline Parameter & Quallfier & Result & $\mathrm{DL}$ & RL Units & DF & Analyst Date & Time & Batch & $\mathbf{M}$ \\
\hline \multicolumn{10}{|l|}{ Metals Analysis } \\
\hline Silver & $\mathbf{U}$ & 135 & 204 & 204 UGKG & 1.0 & NRM 08/24/95 & 2011 & 71530 & 1 \\
\hline Aluminum & & 317000 & 976 & 1640 UGKG & 1.0 & & & & \\
\hline Arsenic & & 11500 & 153 & 410 UOKG & 1.0 & & & & \\
\hline Barium & & 3150 & 5.44 & 246 UGKG & 1.0 & & & & \\
\hline Beryllium & $\mathrm{J}$ & 6.77 & 0.935 & 246 UGKG & 1.0 & & & & \\
\hline Calcium & & 2890000 & 1640 & 1640 UGKO & 1.0 & & & & \\
\hline Cadmium & & 6670 & 7.95 & 164 UGKG & 1.0 & & & & \\
\hline Cobalt & & 9300 & 14.4 & 328 UGKG & 1.0 & & & & \\
\hline Chromium & & 1330 & 48.9 & 328 UOKG & 1.0 & & & & \\
\hline Copper & & 14700 & 44.2 & 328 UGKG & 1.0 & & & & \\
\hline Iron & & 696000 & 828 & 1480 UGKG & 1.0 & & & & \\
\hline Potassium & & 5770000 & 527 & 41000 UOKG & 1.0 & & & & \\
\hline Magnesium & & 647000 & 193 & 1640 UGKG & 1.0 & & & & \\
\hline Manganese & & 45600 & 7.89 & 164 UOKG & 1.0 & & & & \\
\hline Sodium & & 5500000 & 1280 & 8200 UGKG & 1.0 & & & & \\
\hline Nickel & & 17100 & 66.2 & 820 UGKG & 1.0 & & & & \\
\hline Lead & & 6170 & 92.7 & 410 UGKG & 1.0 & & & & \\
\hline Antimony & & 2170 & 78.6 & 410 UGKG & 1.0 & & & & \\
\hline Selenium & & 4410 & 117 & 410 UGKG & 1.0 & & & & \\
\hline Thallium & $\mathrm{U}$ & -886 & 170 & 410 UGKG & 1.0 & & & & \\
\hline Uranium by ICP & & 105000 & 494 & 1640 UGKG & 1.0 & & & & \\
\hline Vanadium & $\gamma$ & 798 & 19.2 & 820 UGKG & 1.0 & & & & \\
\hline Zinc & & 120000 & 221 & 410 UGKG & 1.0 & & & & \\
\hline
\end{tabular}

The following prep procedures were performed: TRACE 


\section{GENERAL ENGINEERING LABORATORIES}

Mecting today's needs with a vision for tomorrow.

CERTIFICATE OF ANALYSIS

\begin{tabular}{lll}
\multicolumn{3}{c}{ Labaratory Certiflcations } \\
STATE & GEL & EPI \\
FL & E87156/87294 & E87472/87458 \\
NC & 233 & \\
SC & 10120 & 10582 \\
TN & 02934 & \\
VA & 00151 & \\
WI & 09988770 &
\end{tabular}

Client: Westinghouse Sayannah River Co.

EPD-Building 773-58 A

Aiken, South Carolina 29808-0001

Contact: Mr. Bob Craig

Project Description: Analytical Services for SRS Environmental Characterization

cc: WSRC00193

Report Date: September 01, 1995

Page 1 of 2

$\begin{array}{ll}\text { Sample ID } & : \text { STED-2 } \\ \text { Lab ID } & : 9508156-18 \\ \text { Matrix } & : \text { Soil } \\ \text { Date Collected } & : 07 / 20 / 95 \\ \text { Date Received } & : 08 / 02 / 95 \\ \text { Priority } & \text { : Routine } \\ \text { Collector } & : \text { Client }\end{array}$

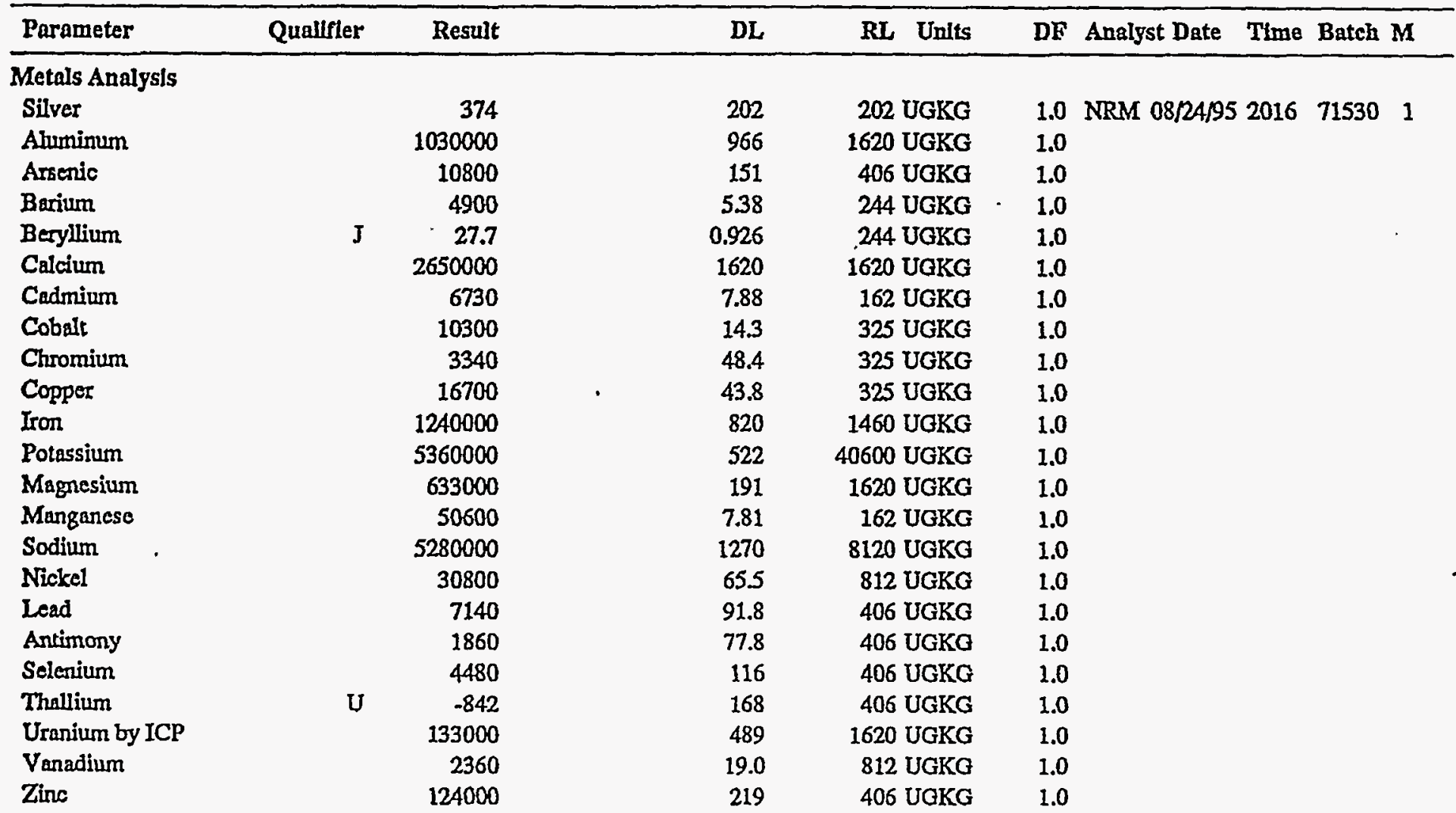

The following prep procedures were performed: 


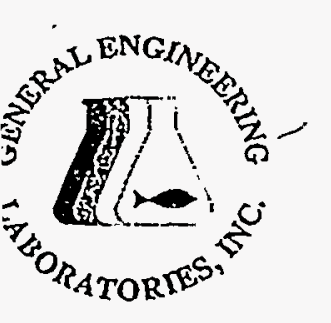

\section{GENERAL ENGINEERING LABORATORIES}

Meeting today's needs with a vision for tomorrow.

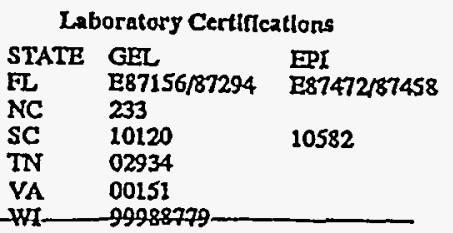

Client: Westinghouse Savannah River Co.

EPD-Building 773-58A

Aiken, South Carolina 29808-0001

Contact: Mr. Bob Craig

Project Description: Analytical Services for SRS Environmental Characterization

Report Date: September 01, 1995

Page 1 of 2

$\begin{array}{ll}\text { Sample ID } & : \text { STED-3 } \\ \text { LabID } & : 9508156-19 \\ \text { Marrix } & : \text { Soil } \\ \text { Date Collected } & : 07 / 20 / 95 \\ \text { Date Received } & : 08 / 02 / 95 \\ \text { Priority } & : \text { Routine } \\ \text { Collector } & : \text { Client }\end{array}$

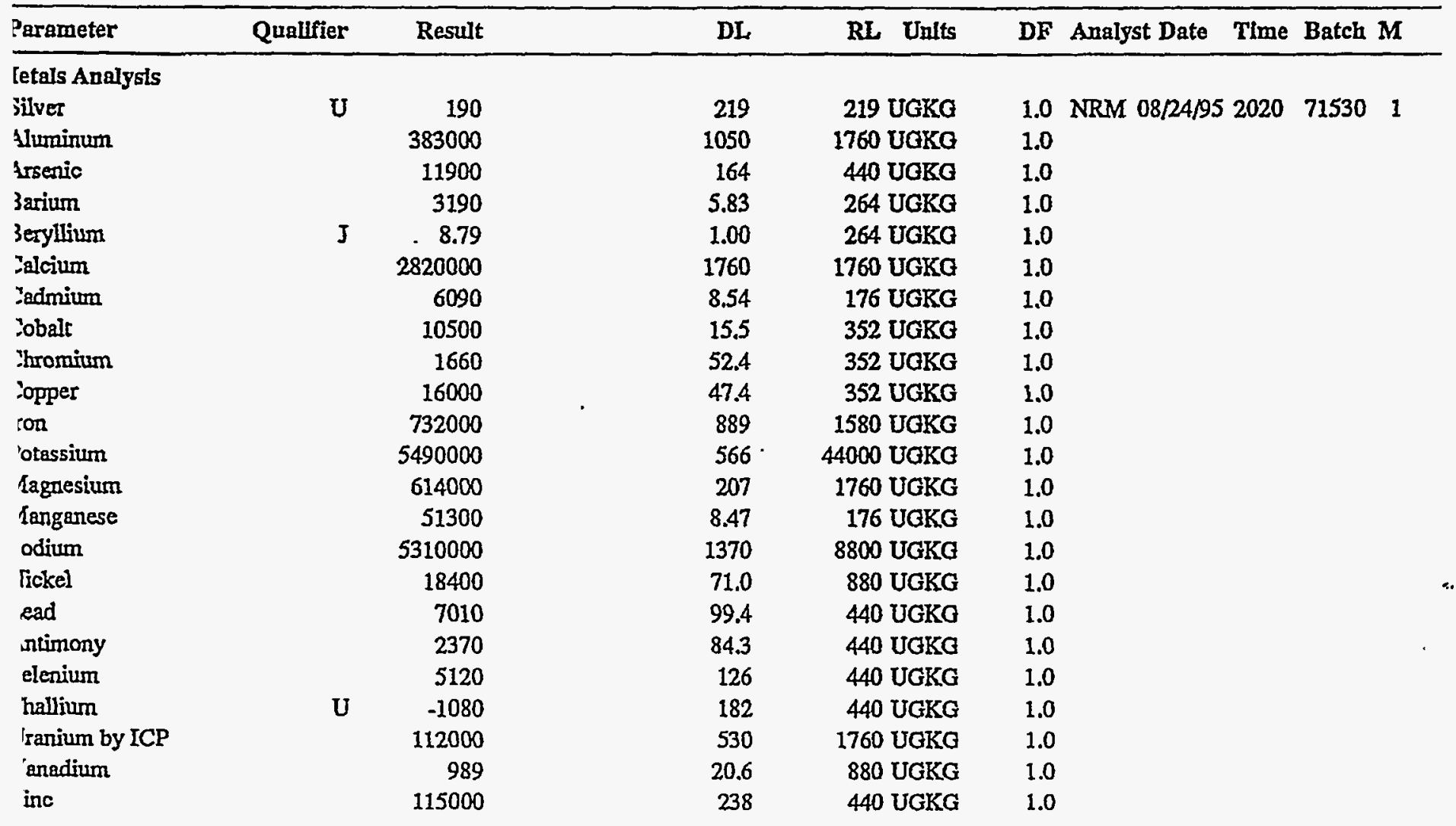

le following prep procedures pere performed:

RACE 